\title{
The Architecture and Evolution of the Singhbhum Craton
}

Formerly of Department of Geology, University of Calcutta; Email : dhruba_38@yahoo.co.uk; abdul.aindia@gmail.com

(Received : 06/04/2019; Revised accepted : 07/08/2019)

https://doi.org/10.18814/epiiugs/2020/020002

The Singhbhum Craton is built up by successive pulses of discrete granitic magmatism at $3.52 \mathrm{Ga}, \sim 3.47-3.43$ $\mathrm{Ga}$, and $\sim 3.40-3.35 \mathrm{Ga}$ that produced tonalitetrondhjemite-granodiorite (TTG)-type suites and were followed by younger pulses at 3.32-3.35 Ga, and 3.313.28 Ga producing voluminous granitic-granodioritic magma. There is enough evidence to indicate that continental crust building activity started in the Hadean time and continued through Eoarchean. But the rocks of this period were fully recycled to generate the Paleoarchean and younger crust. The different pulses of granitic magmatism during the Paleoarchean were interspersed with the formation of supracrustal rocks which are now preserved as supracrustal belts peripheral to the craton or as internal screens within the craton. Halfnium isotopic record suggests that the Hadean and Eoarchean granitoids were sourced in an enriched reservoir, probably some form of early mafic protocrust. From 3.6-3.5 Ga a shift in the isotopic composition of $\mathrm{Hf}$ is noticed, marked by upward excursion of $\varepsilon_{\mathrm{Hf(t)}}$ plots towards suprachondritic values, signifying that the early mantle reservoir was serially modified by contamination by a juvenile melt derived from a depleted source. This probably signals a change in the geodynamic scenario, major depletion of the mantle and generation of voluminous TTG melts. There are contending hypotheses of plume-driven and subduction-driven mechanisms of continental crust formation. In the Singhbhum Craton during Hadean and Eoarchean times episodic mantle plumes probably operated in a stagnant lid tectonic setting. Repeated plume activities and the formation of oceanic plateaus might have triggered the onset of subduction which at the initial stages might have been of short duration. The transition from plume-driven tectonics to subduction-driven tectonics might have taken place at about $3.5 \mathrm{Ga}$. The supracrustal belts of the Older Metamorphic Group (OMG) and the Iron Ore Group
(IOG) are thought to have formed in supra-subduction settings. Widespread metamorphism and deformation affected the craton during 3.34-3.26 Ga. By 3.1 Ga the Singhbhum Craton had stabilized and emerged as a landmass. Paleosols developed on the surface; rift basins were formed which were receptacles of siliciclastic sediments and mafic volcanics; anorogenic K-feldspar bearing granites were emplaced. Swarms of mafic dykes of Paleo- to Meso-Proterozoic age intruded the craton marking a tensional regime that was probably related to the initial stage of basin formation in the North Singhbhum Mobile Belt.

\section{Introductory Remarks}

In most shield areas of the world expansive granitoid terranes are either flanked by or have internal screens of supracrustal belts in varying metamorphic states (Anhaeusser, 2010; Anhaeusser et al., 1969; Nisbet, 1987; Nutman et al., 1989; Iizuka et al., 2007). The oldest known continental crust on the Earth is the Acasta Gneiss Complex ( 4.0 Ga) of the Slave Province of Canada (Bowring et al., 1989; Bowring and Williams, 1999). The oldest known supracrustal belts are the Isua supracrustal belt (3.7-3.8 Ga) from Greenland (Nutman et al., 1997) and the Nuvvuagittuq supracrustal belt (> 3.8 Ga) from the northern Superior Province of Canada (O’Neil et al., 2012; Cates et al., 2013). These mafic-dominated supracrustal belts are thought to represent segments of the ancient oceanic crust and their isotopic characters provide information about the Hadean and Eoarchean mantle (Furnes et al., 2009; O’Neil et al., 2012). Evidence is also accumulating about the existence of continental crust in Hadean times (4.0-4.5 Ga) from study of zircon grains in Archean sediments and xenocrystic zircon grains in granitic gneisses (Compston and Pidgeon, 1986; Nelson et al., 2000; Wilde et al., 2001; Wyche et al., 2004; Iizuka et al., 2006; Duo et al., 2007; Harrison, 2009; Nadeau et al., 2013). In recent years more refined isotopic studies of Pb, Sm, $\mathrm{Nd}, \mathrm{Lu}, \mathrm{Hf}$, and particularly of short lived isotopes and oxygen isotopes have provided new information on the processes of crustal growth during the Hadean time and on the physical and chemical conditions existing on the surface of the early Earth (Bowring and Housh, 1995; Moorbath and Whitehouse, 1996; Kemp et al., 2010). However, how much of the Archean felsic continental crust was juvenile and how much of it was due to reworking of older crusts is a 
matter of debate (Harrison, 2009; Iizuka et al., 2009; Zeh et al., 2009, 2011; Kemp et al., 2010; Guitreau et al., 2012; Kröner et al., 2013, 2014; Hoffmann et al., 2014, 2016; Wan et al., 2015; Reimink et al., 2016). The distribution and structure of the supracrustal belts (maficdominated) and the granitoid bodies suggest density driven sinking of supracrustals and diapiric rise of granitoids which may be fault controlled (Hickman, 1984; Marshak et al., 1992; Collins et al., 1998). Another important question in Archean geodynamics is whether early crustal growth is driven by subduction or by plume dictated underplating or intraplating. The Singhbhum craton with its supracrustal belts and the granitoid terrains of Paleoarchean to Neoarchean age is an ideal terrain to test the different models of Archean crustal growth. The present review is based on an abridged article submitted as the Status Report on the Singhbhum Craton to the Indian National Science Academy.

\section{Geological Setting of the Singhbhum Craton}

Singhbhum Craton (SC) (also designated as Iron Ore Craton, Saha, 1994), one of the oldest cratonic blocks in Peninsular India, encompasses an area of $\sim 39,000 \mathrm{~km}^{2}$ and forms a N-S elongate ovoid block (between $84.5^{\circ} \mathrm{E}$ to $86.5^{\circ} \mathrm{E}$ and $21^{\circ} \mathrm{N}$ to $22.75^{\circ} \mathrm{N}$ ) in eastern India (Fig. 1). Different supracrustal sequences and granitoid rocks ranging in age from 3.5 to 2.5 Ga have built up the craton (Mukhopadhyay, 2001; Sarkar and Gupta, 2012). In the north, the North Singhbhum Mobile belt (NSMB) is thrusted over the SC along the arcuate Singhbhum Shear Zone (SSZ) that has developed within the NSMB close to the cratonic boundary and it had been reactivated multiple times (Matin et al., 2012 and references therein). The SSZ is considered to fork into two branches in the west, and the southern branch is thought to veer towards SW forming the boundary between the NSMB and the SC (Fig. 1) (Saha, 1994). The boundary so drawn would pass north of the Ongarbira Volcanics body. However, studies in the Sonua-Lotapahar region (Mukhopadhyay et al., 1990; Blackburn and Srivastava. 1994) suggest that the east-west trending northerly plunging Ongarbira syncline represents the easterly closure of a regional sheath fold within the ductile shear zone at the interface of NSMB and SC and is not a part of the SC. Therefore, it is proposed that the boundary of the NSMB enveloping the SC is to be drawn south of the Ongarbira volcanics and not as it is customarily shown (e.g., in Saha, 1994). The exact location of the boundary is yet to be established by detailed studies in this region.

To the east, the SSZ curves southeastward and recently Chatterjee et al. (2010) proposed that a N to NNE-trending, sinistral

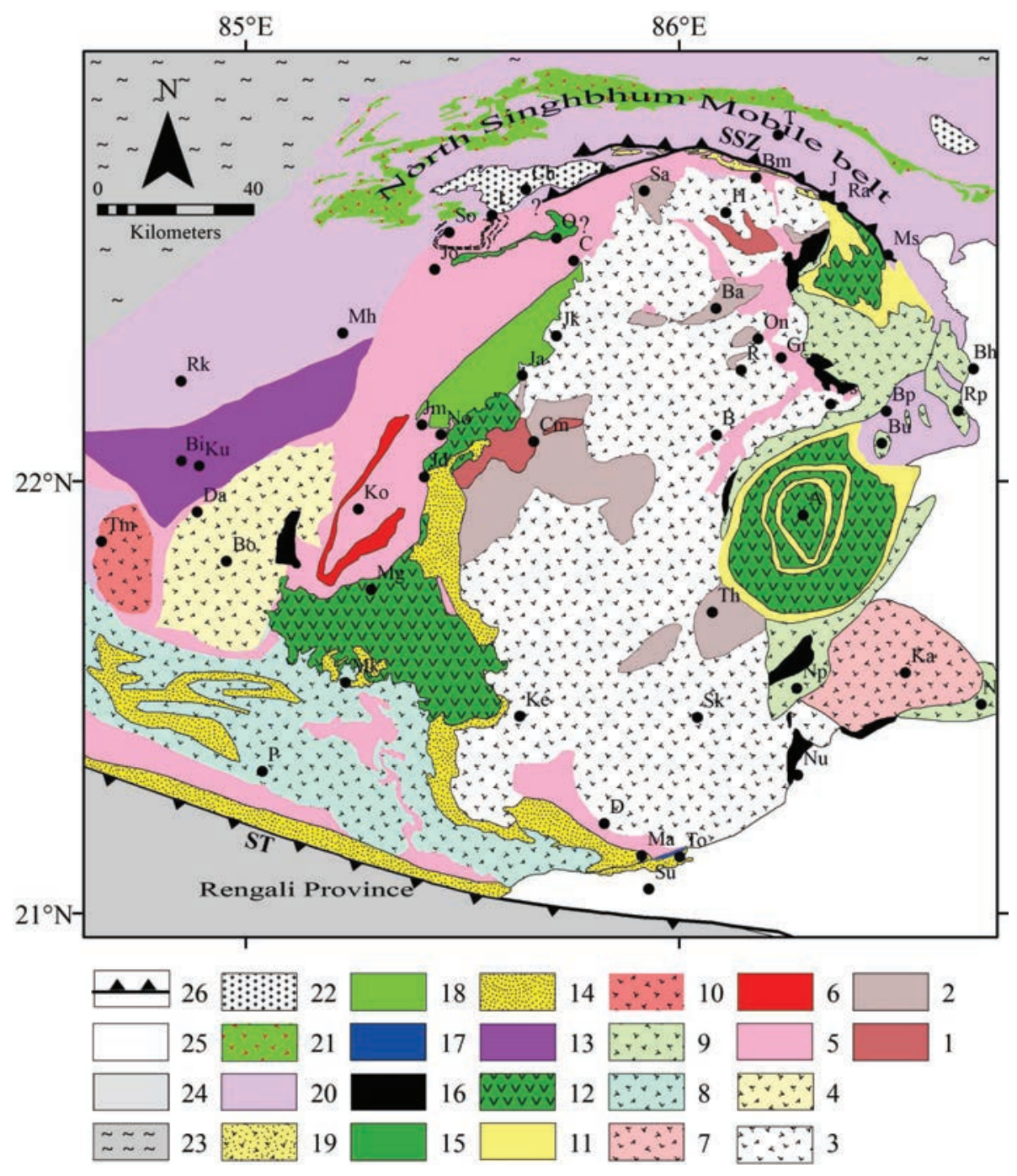

Figure 1. Simplified geological map of the Singhbhum craton (after Saha, 1994 and modified from other sources mentioned in the text). 1- OMG 2 -OMTG 3 -Singhbhum Granite, 4 - Bonai Granite, 5 - Iron Ore Group, Malayagiri Supracrustals, 6 - BIF in western IOG, 7 - Kaptipada Granite, 8 - Pallahara Gneiss, 9 - Mayurbhanj Granite, 10 - Tamperkola Granite, 11 - Dhanjori Siliciclastics, 12 - Dhanjori - Simlipal - Jgannathpur - Malangtoli Volcanics, 13 - Darjing Group, 14 -Mahagiri - Keonjhar - Mankaharchua - Deograh Siliciclastics, 15 - Ongarbira Volcanics, 16 - Gabbro - anorthosite - ultramafics, 17-Sukinda Ultramafics, 18 - Kolhan Group, 19 - Soda Granite, Arkasani Granite, Kuilapal Granite, Beldih Granite, 20 - Singhbhum Group, 21 - Dalma Volcanics, 22 - Chakradharpur Granite, 23 - Chhotanagpur Granite Gneiss, 24 - Rengali Province, 25 - Gondwanas, Younger Sediments and Alluvium, 26 -Shear Zone/Fault.

A - Amjhor, B - Badampahar, Ba - Bahalda, Bh - Baharagora, Bi - Birtola, Bm - Bisrampur, Bn - Brahmani, Bo - Bonai, Bp - Bangriposi, Br - Bhaunra, Bs - Besoi, Bu - Bhuasuni, C - Chaibasa, Ch - Chakradharpur, Cm - Champua, D - Daitari, Da Darjing, Gr - Gorumahisani, H - Haludpukur, J - jaduguda, Ja - Jagannathpur, Jd - Joda, Jk- Jorapokhar, Jm - Jamda, Jo - Jojuhatu, Ka - Kaptipada, Ke - Keonjhar, Ko - Koira, Ku - Kumakela, L - Lotapahar, Ma - Mahagiri, Mg - Malangtoli, Mh - Manoharpur, Mk Mankaharchua, Ms-Mosabani, $\mathrm{N}$ - Nilgiri, No-Noamundi, $\mathrm{Np}$-Notopahar, $\mathrm{Nu}$ - Nuashahi, O - Ongarbira, On - Onlajori, P - Pallahara, $R$ - Rairangpur, Ra - Rakha, Rk - Raurkela, Rp - Romapahari, Sa - Seraikela, Sk - Satkosia, So - Sonua, Su - Sukinda, T - Tatanagar, Th - Thakurmunda, Tm - Tamperkola, To - Tomka. The Singhbhum Group, the Dalma Volcanics and other associated rocks constitute the North Singhbhum Mobile Belt. 
transcontinental deformation zone, named as the Eastern Indian Tectonic Zone (EITZ), runs along the eastern fringe of the SC and continuing northward cuts across the SSZ; it defines the eastern edges of the SC, the NSMB and the Chhotanagpur Gneissic Complex. The timing of tectonism in the EITZ, has been placed at 876 - 784 Ma.

To the south of the SC lies the high grade Rengali Province (RP), separated by the Barakot-Akul Fault Zone (BAFZ) (Crowe et al., 2003) and its eastern continuation, the Sukinda Thrust (Prasada Rao et al., 1964; Banerjee, 1972) (Fig. 1). The RP, intervening between the Eastern Ghats Granulite Belt and the SC, is thrusted over the latter (Bose et al., 2015). Ghosh et al. (2016) suggested that the RP shows imprints of a major 500 Ma transpressive deformation resulting from oblique collisional accretion of the Eastern Ghats Granulite Belt to the Singhbhum Craton during the Pan-African orogeny. Bose et al. (2015) and Mahapatro et al. (2012) have interpreted the granulite facies lenses within the gneisses of the RP to represent thrusted slices of the deeper crust of the SC.

Four principal units make up the SC: (1) Older Metamorphic Group (OMG) and Older Metamorphic Tonalite Gneiss (OMTG), (2) large granitic massifs of Singhbhum Granite (SBG), Bonai Granite (BG), Kaptipada (Nilgiri) Granite (KG), Mayurbhanj Granite (MBG) and Pallahara Gneiss (PG), (3) supracrustal rocks of several Iron Ore Basins, and (4) belts of younger supracrustal rocks. In addition to these, there are the Malangtoli Volcanics, the Jagannathpur Volcanics and the Ongarbira Volcanics, the dyke swarms of Newer Dolerite, and the intrusive bodies of ultramafics-gabbro-anorthosite suite. Insufficient geochronological data and rarity of contact relations in outcrops have hampered the understanding of temporal relation between these groups. The different units are referred to in some recent publications (Prabhakar and Bhattacharya, 2013; Dey et al., 2017) as lihodemic units; thus it has been recommended that the OMTG should be named as Champua Suite, the Singhbhum Granite (SBG) as Singhbhum Suite etc. We prefer to retain the existing names till more geochronological dates are available and the units of different ages are separately mapped.

\section{Granitoid Rocks in the Singhbhum Craton}

\section{Older Metamorphic Tonalite Gneiss (OMTG)}

The type area of the OMTG rocks is the $\sim 900 \mathrm{~km}^{2}$ outcrop east and south of Champua; smaller outcrops are also found near Seraikela, Onlajori, Bahalda, Rairangpur and Thakurmunda (Fig. 1). Prabhakar and Bhattacharya (2013) restrict the term OMTG only to the enclaves of migmatitic tonalite gneisses within the Singhbhum Granite (SBG). The bulk of what is shown as OMTG near Champua in the map of Saha (1994) (Fig. 1) belongs, according to them, to the TTG suite of Phase I of the Singhbhum Granite. This point is to be settled by careful field mapping coupled with more petrographical, geochemical and geochronological data. The OMTG is typically tonalite-trondhjemitegranodiorite (TTG) in composition (Fig. 2a) with similarity to the Archean TTG rocks in other parts of the world. Field relations in outcrops indicate successive phases of intrusive activity. Upadhyay et al. (2014) and Pandey et al. (2019) have included some rocks compositionally falling in the granite field within the OMTG. However, the tonalite and the granite have different zircon dates, different REE patterns and different geochemical characterstics. We
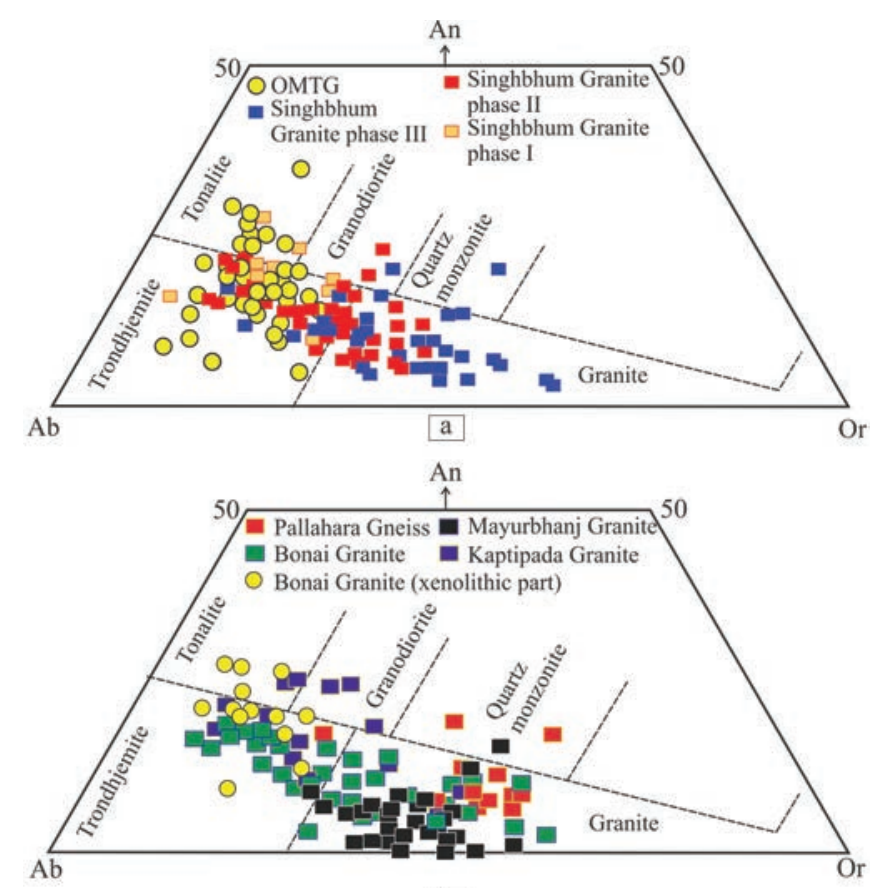

b

Figure 2. $a$ and $b$. Normative Ab-An-Or plots of granitoid rocks in the Singhbhum Craton. Data source: Saha et al. (1984), Sengupta et al. (1991), Saha (1994), Tait et al. (2011), Nelson et al. (2014), Upadhyay et al. (2014), Dey et al. (2017), Pandey et al. (2019).

are of the opinion that the granite samples should not be grouped with the TTG as parts of the OMTG. While Saha et al. (1988) regarded the OMTG to be synkinematically intruded into the Older Metamorphic Group (OMG), Prabhakar and Bhattacharya (2013) remarked that unambiguous intrusive relationship between the OMG and the OMTG is lacking.

The REE in the tonalitic samples show gently sloping pattern with LREE enrichment, no or weak Eu anomaly and flat or gently sloping HREE plot (Fig. 3a), while the OMTG granite samples show strong negative Eu-anomaly and nearly flat HREE pattern (Fig. 3a). Nelson et al. (2014) presented a model of tonalite derivation by fluid absent partial melting of a lower crustal source with retained restitic feldspar following melt extraction. Dey et al. (2017) and Pandey et al. (2019) proposed similar models of dehydration melting of a mafic source in absence of garnet with plagioclase as residual or fractionating phase. The minimum temperature of the tonalite magma corresponding to the enclave has been estimated from zircon saturation temperature to be $\sim 750^{\circ} \mathrm{C}$, and the pressure at the emplacement depth is determined from $\mathrm{Al}$ in hornblende to be $3.5+0.1 \mathrm{~kb}$ ( $12 \mathrm{~km}$ depth) (Dey et al., 2017).

The radiometric dates obtained from the OMTG samples by different workers span a wide range. The whole-rock isochron ages and the ${ }^{207} \mathrm{~Pb} /{ }^{206} \mathrm{~Pb}$ concordant ages from zircon grains are tabulated in Table 1 and plotted in Figure 4. The geochronological data suggest that the TTG suite in the OMTG was emplaced in different pulses at 3.52, 3.47-3.43 and $~ 3.40-3.33 \mathrm{Ga}$; xenocrysts of 3.41-3.47 Ga old zircon from the older pulse are present in the younger TTGs. The granitic components are distinctly younger at 3.31-3.28 Ga. The major metamorphic pulses were at $\sim 3.3-3.2,3.14-3.11,2.96-2.95$ and 2.45 $\mathrm{Ga}$. The ages of inherited zircons (xenocrystic cores) from older rocks range from $\sim 4.2$ to $3.6 \mathrm{Ga}$. It is important to note that the $3380 \pm 11$ 


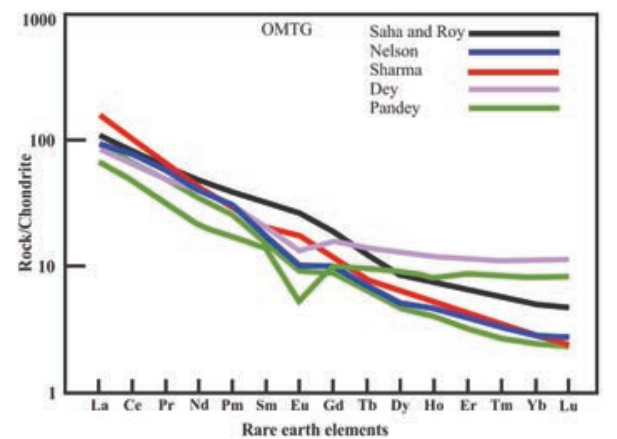

a]

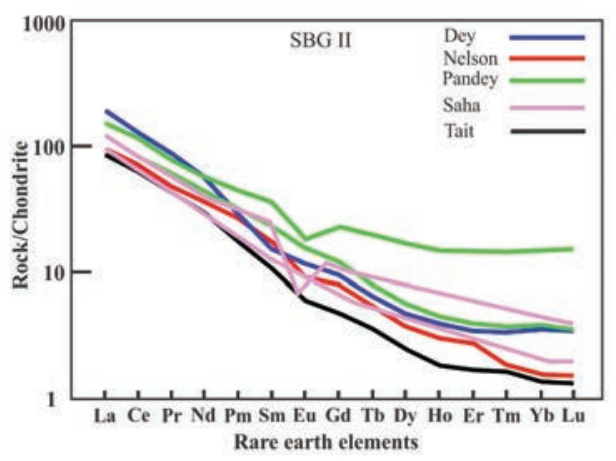

C

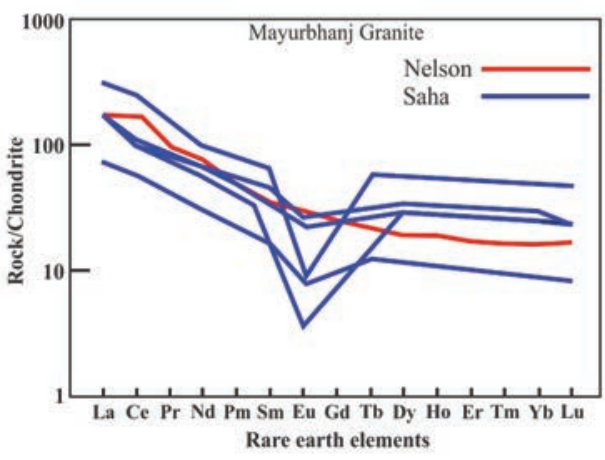

e

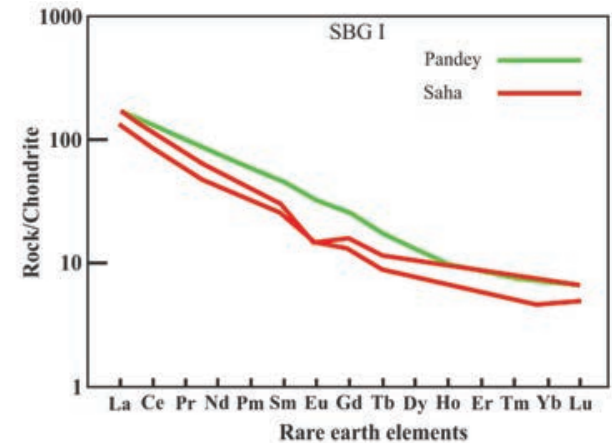

b

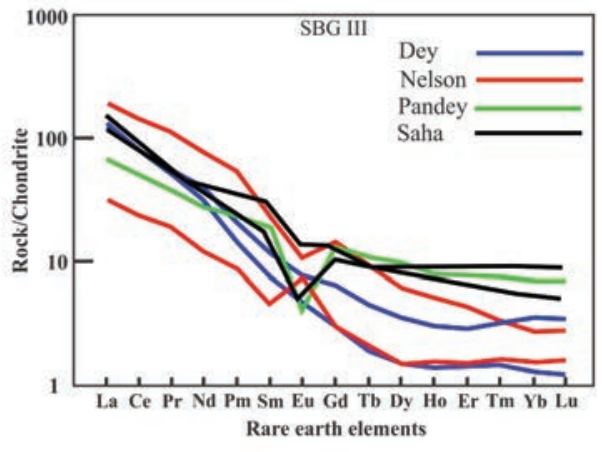

d]

Figure 3. a-e. REE patterns in different plutonic units in the Singhbhum Craton from different sources. Selected curves from different sources are shown. Note the variability within each unit. See text for discussion. Data source : Saha and Ray (1984), Saha (1994), Sharma et al. (1994), Tait et al. (2011), Nelson et al. (2014), Dey et al. (2017), Pandey et al. (2019).

Ma old granitoid in Deo River near Jagannathpur (Nelson et al., 2014) displays rafts of BIF and is clearly intrusive unto the latter.

Most samples of the OMTG have positive $\varepsilon_{\mathrm{Nd}(\mathrm{t})}$ values ranging from 0.55 to 1.75 and are derived by melting of the igneous precursors (OMG amphibolite). Other samples of the OMTG have negative $\varepsilon_{\mathrm{Nd}(\mathrm{t})}$ value and are derived by melting of ancient crustal rocks or from a somewhat enriched mantle which were 150-450 million years older than the OMG amphibolite.

Chaudhuri et al. (2018) reported that the Eoarchean ( 3.7 Ga) cores of zircons in the OMTG and the Paleoarchean ( 3.6 to 3.3) zircon grains in the OMTG have negative $\varepsilon_{\mathrm{Hf}(\mathrm{t})}$ values of $-4.7 \pm 1.4$ to $-6.6 \pm 1.1$ and $-0.4 \pm 1.2$ to $-3.7 \pm 1.8$ respectively (Fig. 5). They interpret that the Hadean enriched reservoir, from which the felsic melts were derived, persisted at least till Paleoarchean, but these were variably mixed with depleted mantle-derived juvenile magma during Eoarchean to Paleoarchean. On the contrary, Dey et al. (2017) reported suprachondritic Hf isotopic signatures with positive values of $\varepsilon_{\mathrm{Hf}(\mathrm{t})}$ ranging from +2.9 to +2.2 and concluded that the $3.47 \mathrm{Ga}$ old tonalite was generated by shallow melting of a juvenile mafic crust. Pandey et al. (2019) reported weak subchondritic to suprachondritic $\varepsilon_{\mathrm{Hf}(\mathrm{t})}$ values of -1.2 to +4.5 for the Paleoarchean OMTG zircon grains (Fig. 5). This implies the existence of a separate depleted reservoir during Paleoarchean which was probably complementary to the ancient enriched reservoir inferred by Chaudhuri et al. (2018). Therefore, it appears that different sources contributed to different pulses of the OMTG.

\section{Singhbhum Granite (SBG)}

The large oval-shaped body of the Singhbhum Granite (SBG) constitutes more than one-third of the Singhbhum craton (Fig. 1). It is a suite of granitoid rocks ranging in composition from tonalite to granite and emplaced in different pulses. Professor A. K. Saha and his co-workers demarcated the complex granite body into 12 separate units on the basis of mutual intrusive relations and distinctive primary foliation pattern of the different units (Saha, 1972, 1994; Saha and Ray, 1984). The 12 domal magmatic bodies were grouped into three closely related phases which were emplaced successively. The earliest phase (Phase I) is relatively K-poor, granodioritetrondhjemite in composition, while the later phases (Phases II and III) are granodiorite that grade to monzogranite and granite (Saha, 1994) (Fig. 2a). Phase III covers the largest area of the SBG complex. Later work has brought into light greater range in composition of the different units of the SBG (Fig. 2a). It is now evident from a larger database that the OMTG and the three phases of the SBG have overlapping composition. However, the OMTG rocks are exclusively TTGs (tonalite-trondhjemitegranodiorite), whereas the SBG rocks are granite, monzogranite, granodiorite and trondhjemite (Fig. 2a).

According to Saha (1994) and Pandey et al. (2019) the Phase I is characterized by smoothly sloping REE pattern with fractioned LREE and moderately fractionated HREE and with or without negative Euanomaly (Fig. 3b). Some samples of Phase II show sloping REE patterns similar to that of OMTG, while other samples show strong negative Eu-anomaly (Fig. 3c) (Saha, 1994; Tait et al., 2011; Nelson et al., 2014; Dey et al., 2017; Pandey et al., 2019). In Phase III, REE patterns show fractionated LREE, flat HREE or slightly fractionated HREE and negative Eu-anomaly, but some granodiorite samples show 


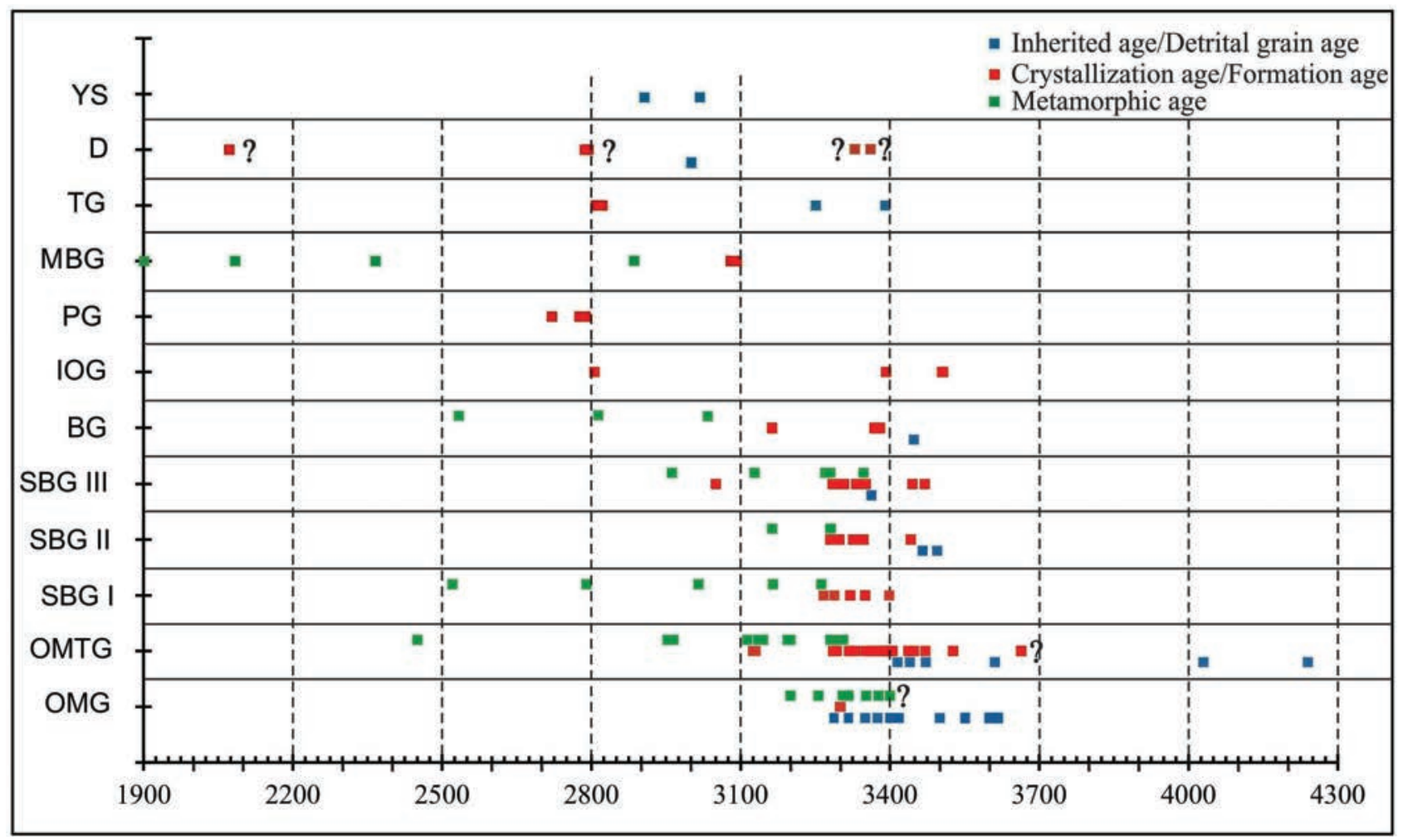

Figure 4. Radiometric dates from the different units in the Singhbhum Craton from all sources, (Data from Table 1). Mostly concordant zircon ages are shown. Rb-Sr ages are shown as metamorphic ages. D - Dhanjori Group, YS - Younger siliciclastic rocks like Keonjhar Quartzite etc. Other abbreviations are as in the text.

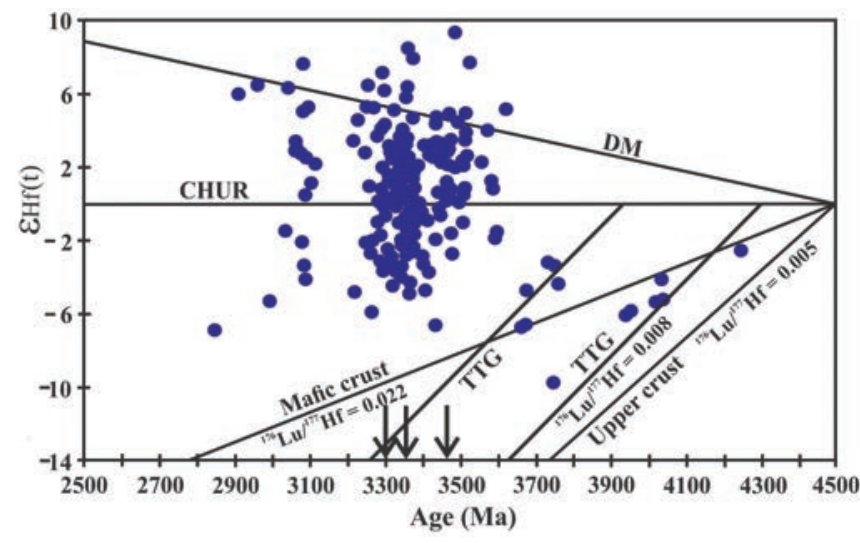

Figure 5. $\varepsilon_{\mathrm{Hf(t)}}$ vs. age plots of magmatic and detrital zircon grains from the Singhbhum Craton (modified from Sreenivas et al., 2019; data source: Chaudhuri et al., 2018, Miller et al., 2018, Sreenivas et al., 2019, Pandey et al., 2019, Olierook et al., 2019). DM-Depleted mantle curve for mantle extraction at 4.5 Ga. Mafic crust (enriched reservoir) curve for ${ }^{176} \mathrm{Lu} /{ }^{177} \mathrm{Hf}=0.022$ fits the plots for the Hadean and Eoarchean zircon grains. The isotopic trajectory of the upper continental crust that formed at $4.5 \mathrm{Ga}$ is drawn for the ${ }^{176} \mathrm{Lu} /{ }^{177} \mathrm{Hf}$ ratio of 0.005. The Hadean-Eoarchean grains (>3.7Ga) lie within a band around a TTG trajectory with ${ }^{176} \mathrm{Lu} /{ }^{177} \mathrm{Hf}=0.008$ that corresponds to a TTG like source that formed at 4.3-4.2 Ga. The younger Eoarchean grains lie on a trajectory that corresponds to a TTG-like source that formed at $\sim 3.95 \mathrm{Ga}$. Note that the excursion of the $\varepsilon_{\mathrm{Hf(t)}}$ towards positive values starts at $\sim 3.5 \mathrm{Ga}$. The three distinct periods of crust formation in Singhbhum are indicated by three arrows at the bottom. no Eu anomaly and a monzogranite even shows positive Eu anomaly (Fig. 3d). Petrographically and in REE pattern the different units of SBG show more variability than originally supposed by Saha (1994).

Petrogenetically most of the Singhbhum granitoid samples fall in low to medium pressure category (Pandey et al., 2019). The minimum value of magma temperature as estimated from zircon saturation temperature is $800^{\circ} \pm 30^{\circ} \mathrm{C}$ for a porphyritic granite/ trondhjemite from a Phase II pluton and $754^{\circ} \pm 13^{\circ} \mathrm{C}$ for a nonporphyritic granite from a Phase III pluton. Pandey et al. (2019) have pointed out that all the granitoids in the SC have broadly similar geochemical characters and REE patterns which hint towards the derivation of these granitoids by differentiation of chemically and mineralogically similar source(s).

The commonly observed steep dipping foliation in the SBG was considered to be primary by Saha (1994). Prabhakar and Bhattacharya (2013) contested this view and recognized a single set of tectonic foliation in the SBG granitoids along with different sets of locally developed shear zones. There are two macroscopic NNE-SSW striking shear zones, the western Champua Shear Zone (CSZ) along the boundary between the OMG and the SBG, and the eastern Rairangpur Shear Zone (RSZ) within the SBG, both showing sinistral-normal (west-down) shear sense. Prabhakar and Bhattacharya (2013) opined that the deformation textures in SBG developed in response to the ubiquitous $\mathrm{D}_{4}$ shearing. The bulk of the pluton shows low temperature deformation textures, implying that the rocks cooled appreciably below the solidus prior to deformation, while along the western margin of the pluton the granitoids were emplaced later and were deformed while still hot, giving rise to high temperature deformation textures. They hypothesized that a period of crustal shortening led to the accretion of the western Iron Ore Belt to the OMG-OMTG basement, 
and this was followed by extensional tectonism marked by the ascent and emplacement of the granitoids of the SBG pluton in pulses along steep-dipping sinistral-normal ductile shear zones. However, the geochronological evidence is inadequate to confirm this hypothesis.

Recent geochronological data (Table 1; Fig. 4) throw doubt on the three-phase chronology of the SBG as proposed by Saha and his co-workers. The data clearly show that there is no systematic age difference between the OMTG, the SBG Phase I, the SBG Phase II and the SBG Phase III, as these are defined now. However, there are different pulses of intrusion of granitic magma, and xenocrysts from older pulse are recognized in the younger ones. The total period of granitic intrusion lasted from 3.52 to $3.28 \mathrm{Ga}$ and distinct pulses are dated at 3.52 Ga (only in OMTG), 3.43-3.47 Ga (noted in OMTG and SBG III), 3.35-3.40 Ga (noted in OMTG only), 3.32-3.35 Ga (noted in OMTG, SBG I, SBG II and SBG III), and 3.30-3.28 Ga (noted in OMTG, SBG II and SBG III). It is also to be noted that the younger 3.28-3.30 ages in the OMTG come from samples of OMTG granites and not tonalites. We are of the view that such samples of granite are not to be placed within OMTG. Similarly we recommend that the 3470 Ma trondhjemite (Pandey et al. 2019) and 3445 Ma granite (Upadhyay et al., 2014) be taken out of Phase III and be placed within the OMTG. Olierook et al. (2019) have recommended to place the boundary between the OMTG and the SBG at ca. 3380-3365 $\mathrm{Ma}$, which marks the cessation of trondhjemite magmatism and the onset of monzogranite emplacement. However, more mineralogical, geochemical and geochronological data are necessary to fix a firm boundary between magmatic pulses having distinct compositional characteristics. It is interesting to note that the ages of detrital zircon grains in the river sand reported by Miller et al. (2018) show a prominent peak at $\sim 3.35 \mathrm{Ga}$ and smaller peaks at $\sim 3.5 \mathrm{Ga}$ and 3.1 Ga.

The $\varepsilon_{\mathrm{Nd}(\mathrm{t})}$ values of the granitoid samples (3291+9 Ma old) from the Phase II Keonjhar-Bhaunra pluton are -0.4 to +0.2 , with $\mathrm{T}_{\mathrm{DM}}$ of $3452 \mathrm{Ma}$ and 3394 Ma respectively, indicating relatively juvenile magma (Tait et al., 2011). Pandey et al. (2019) classified the Singhbhum granitoid samples (OMTG, SBG I, SBG II, SBG III) into older and younger granitoids, and described that their $\mathrm{Sm}-\mathrm{Nd}$ isotopic compositions define linear arrays in the standard Sm-Nd isochron diagram. The apparent ages calculated from these arrays are 3344+160 Ma and 3142 \pm 390 Ma for the older and younger granitoids respectively. The $\varepsilon_{\mathrm{Nd}(\mathrm{t})}$ values of the samples calculated using their respective $\mathrm{U}-\mathrm{Pb}$ zircon crystallization ages have mostly nearchondritic $\varepsilon_{\mathrm{Nd}(\mathrm{t})}$ values. The $\varepsilon_{\mathrm{Nd}(\mathrm{t})}$ values for the older granitoids (3440 $\mathrm{Ma}$ ) range from +0.1 to +2.2 . The younger granitoids (3363-3263 Ma) have $\varepsilon_{\mathrm{Nd}(\mathrm{t})}$ values between -0.2 and +1.6 . A few samples have higher values of +2.7 to +5.2 .

The Hf $\mathrm{T}_{\mathrm{DM}}$ of porphyritic granite from the Phase II KeonjharBhaunra pluton varies from 3396 to $3505 \mathrm{Ma}$ (average 3463_16 Ma), and the average value of $\varepsilon_{\mathrm{Hf}(\mathrm{t})}$ is $+2.7 \pm 0.8$ (Dey et al., 2017). The Hf $\mathrm{T}_{\mathrm{DM}}$ of the nearby non-porphyritic Phase III granite varies from 3376 to $3523 \mathrm{Ma}$ (average $3460 \pm 16 \mathrm{Ma}$ ), and the average value of $\varepsilon_{\mathrm{Hf}(\mathrm{t})}$ is $+2.2 \pm 0.8$. Dey et al. (2017) further reported that the mean $\varepsilon_{\mathrm{Hf(t)}}$ values for the $3.47,3.35$, and $3.30 \mathrm{Ga}$ granitoids from the SBG are $+2.1 \pm 2.8$ to $+4.8 \pm 2.8,+1.8 \pm 3.0$ to $+4.0 \pm 3.6$, and $+0.8 \pm 2.8$ to $+3.7 \pm 2.8$ respectively (Fig. 5 ), suggesting derivation from ancient crustal rocks. They inferred origin through melting of a tonalite dominated source and minor mafic source.

Pandey et al. (2019) report similar, but in general lower, mean

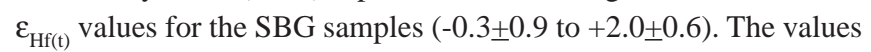
are near-chondritic and Pandey et al. (2019) argue against the recycling of large amounts of much older evolved crust as the source of the granitoids of the SC and opine that the data are more consistent with a primitive near-chondritic mantle source. They have also reported that samples showing high $\varepsilon_{\mathrm{Nd}(\mathrm{t})}$ values of +1.6 to +5.2 (suggesting a strongly depleted source) have near-chondritic $\varepsilon_{\mathrm{Hf}(\mathrm{t})}$ values (suggesting primitive mantle source). They have commented that $\varepsilon_{\mathrm{Nd}(\mathrm{t})}$ is determined from whole rock compositions and is sensitive to later modifications affecting the rocks. The Hf isotopic data from zircon are more robust to later modifications of the whole rock, and hence $\mathrm{Hf}$ isotopes in zircon yield more reliable measures than whole rock $\mathrm{Nd}$ isotopes.

The major relatively high grade metamorphic episode is recorded at 3.34 - $3.26 \mathrm{Ga}$. This is coeval with magmatic episodes in the SBG and the OMTG. Thus magmatism and metamorphism went hand in hand in the Singhbhum Craton. Younger metamorphic resettings are recorded in OMTG and SBG at 3.16-3.11 Ga and 3.0-2.8 Ga. This appears to be broadly synchronous with the emplacement of younger felsic plutons such as the Mayurbhanj Granite (3.1 Ga; Mishra et al., 1999). Still younger dates of 2.45-2.50 Ga are sporadically recorded by zircon in the granitoids and gneisses (Upadhyay et al., 2014).

\section{Other Granite Bodies}

\section{Bonai Granite}

Bonai Granite (BG), the second largest body after the SBG covering an area of $\sim 700 \mathrm{~km}^{2}$ occurs in the south-western corner of the craton and is separated from the SBG by a wide tract of the western Iron Ore Belt or the Jamda-Koira belt (Fig. 1). BG is dominantly porphyritc and equigranular trondhjemite-granodiorite, with subordinate granite (Fig. 2b) (Sengupta et al., 1991, 1993). Geochemically the samples show either calc-alkaline trondhjemitic trend or normal calc-alkaline trend. Both the varieties have low HREE content and flat HREE pattern, moderately enriched LREE and strong to weak negative Eu-anomaly; the pattern is similar to that of SBG Phase III. Xenoliths of trondhjemite-tonalite, banded migmatite, and older supracrustals, such as, quartzite, BIF and mafic-ultramafic rocks are common in both varieties of the BG. Xenolithic trondhjemitetonalite show strongly fractionated sloping REE patterns with enriched LREE, depleted HREE and insignificant Eu-anomaly; the pattern has similarity with that of OMTG/SBG Phase I.

The granitoids of the Bonai Granite have disturbed isotopic systems and have not yielded precise radiometric dates (Table 1, Fig. 4). The dates are similar to the ages of the different components of the SBG. Chakraborty et al. (2019) have recently reported zircon concordia age of 3370 $\pm 10 \mathrm{Ma}$ as the emplacement age, and 3033+38 Ma, 2809+29 Ma, 2531_ 22 Ma as metamorphic/hydrothermal ages.

\section{Tamperkola Granite}

Tamperkola Granite (TG) forms a small body west of the BG and is separated from it by a belt of supracrustal rocks (Fig. 1). The TG is an anorogenic K-feldspar-bearing granite, often with granophyric texture (Bandyopadhyay et al., 2001). The TG shows intrusive relation to the supracrustal rocks belonging to both the IOG and the Darjing Group (described later), and shows no imprints of any deformation or metamorphism features. Zircon grains from the TG have yilded $2809 \pm 12 \mathrm{Ma}{ }^{207} \mathrm{~Pb} /{ }^{206} \mathrm{~Pb}$ age. A subrounded xenocrystic core has yielded ages of $3391 \pm 8$ and $3251 \pm 8$ Ma. The weighted mean age 
$\left({ }^{207} \mathrm{~Pb} /{ }^{206} \mathrm{~Pb}\right)$ of zircon grains in the acid volcanics related to TG is 2822+67 Ma.

\section{Kaptipada (Nilgiri) Granite}

The Kaptipada Granite (KG), also known as the Nilgiri Granite, forms an oval shaped pluton in the southeastern part of the Singhbhum Craton (Fig. 1) and is surrounded on all sides by younger supracrustal and intrusive rocks. It dominantly consists of high- $\mathrm{Al}_{2} \mathrm{O}_{3}$ tonalitetrondhjemite-granodiorite along with subordinate younger granitegranodiorite components (Fig. 2b); enclaves of amphibolite and migmatite are abundant. In the $\mathrm{Y}-\mathrm{Nb}$ and $(\mathrm{Y}+\mathrm{Nb})-\mathrm{Rb}$ tectonic discrimination diagram the plots of the $\mathrm{KG}$ fall in the field of volcanic arc granite. It is characterized by fractionated REE pattern with no Eu anomaly (Saha, 1994), broadly similar to that of OMTG/SBG Phase I and is thought to have been derived by partial melting of an amphibolite with hornblende as a residual phase (Vohra et al., 1991). No precise dates are available from the Kaptipada Granite.

\section{Mayurbhanj Granite}

The Mayurbhanj Granite (MBG) forms a batholithic body, covering $\sim 1000 \mathrm{~km}^{2}$ in the southeastern side of the Singhbhum craton adjacent to the Singhbhum Shear Zone and is intrusive into the SBG and the IOG (Fig. 1). Plots of MBG in the Or-Ab-An diagram mostly fall within the field of granite (Fig. 2b). The MBG is made up of granophyric biotite-hornblende-alkali feldspar granite, ferrohastingsite-biotite granite, and biotite-aplogranite. It is a $\mathrm{K}_{2} \mathrm{O}$ rich suite having slightly enriched LREE with conspicuous negative Eu-anomaly and flat HREE pattern (Saha, 1994; Nelson, 2014) (Fig. 3e); one sample shows no Eu anomaly and high HREE abundance (Fig. 3e). From the geochemical characteristics MBG is considered as an A-type anorogenic granite (Misra, 1999; Misra et al., 2002). Misra et al. (2002) concluded that all the varieties of the MBG pluton were derived from the same parent magma generated by batch melting of the SBG at relatively high temperature $\left(\sim 980^{\circ} \mathrm{C}\right)$ and at low pressures (4 to $<2 \mathrm{~kb}$ ) under anhydrous conditions.

Earlier imprecise Rb-Sr isochron dates indicated Paleoproterozoic age of the MBG (Table 1). More recent age determinations from zircon grains suggest an age of 3.1 Ga (Misra et al., 1999; Nelson et al., 2014; Chakaraborti et al., 2019). The MBG is a Mesoarchean unit involved in Proterozoic deformation and metamorphism because of its proximity to the Proterozoic fold belt of North Singhbhum.

An isolated body of A-type alkali-feldspar and iron-rich biotite and hastingsite bearing granitic gneiss within host mica schists, which was correlated with the MBG by Saha (1994), has recently been named as Bangriposi Granite by Chakraborti et al. (2019). Their REE pattern shows LREE enrichment, prominent negative Eu anomaly and flat HREE. The zircon grains with oscillatory zoning have concordia ages of 3079 $\pm 7 \mathrm{Ma}$ and $3115+10 \mathrm{Ma}$. Hence it appears to be of the same age as the MBG. The $\mathrm{Nd} \mathrm{T}_{\mathrm{DM}}$ is $3.4 \mathrm{Ga}$ and the $\varepsilon_{\mathrm{Nd}(\mathrm{t})}$ varies between +0.5 and +1.4 . It is modelled to have been produced by low degree of partial melting of OMG amphibolite. The maximum pressure estimate is $7.7-7.9 \mathrm{~kb}$, the temperature is of the order of $900^{\circ} \mathrm{C}$, and the $f_{\mathrm{O} 2}$ is low, signifying reducing condition.

\section{Pallahara Gneiss}

The Pallahara Gneiss (PG) occurs in the southwestern part of the craton as an undifferentiated gneissic terrain (Fig. 1). It has an overall compositional range from granite to granodiorite (Fig. 2b). Chemically the rocks are calc-alkaline, ferroan, weakly metaluminous granites, depleted in $\mathrm{Al}, \mathrm{Ca}$ and $\mathrm{Mg}$ and rich in LILE and HFSE and are classified as A-type granites with high $\mathrm{Y} / \mathrm{Nb}$ ratios. In the Y-Nb discrimination diagram their plots fall in the field of within-plate granite. Geochemical characteristics suggest an origin through hightemperature, shallow crustal melting of a tonalite/granodiorite source that is similar to the 3.3 Ga SBG (Topno et al., 2018). Dating of zircon grains suggest the crystallization age of the granite to be $\sim 2.7$ 2.8 Ga (Chattopadhyay et al., 2015; Topno et al., 2018) (Table 1). The intrusion of the Pallahara granitoids is suggested to be coeval with the prominent mafic magmatism in the Singhbhum Craton (e.g., the Dhanjori mafic volcanic rocks and mafic dyke swarm) and with the Tamperkola Granite.

\section{Older Supracrustal Rocks in the Singhbhum Craton}

\section{Older Metamorphic Group (OMG)}

One of the oldest units in the craton is the OMG which occurs as enclaves spread all over within the Singhbhum Granite outcrops (Fig. 1). The type area of the OMG is Champua where the OMG outcrops cover an area of $\sim 200 \mathrm{~km}^{2}$ (Fig. 1). Other important places of occurrence of OMG are near Rairangpur, Onlajori, Bahalda, Haludpukur and Thakurmunda (Fig. 1). The main rock types are upper greenschist to amphibolite facies pelitic schists (biotite + muscovite + quartz \pm garnet \pm sillimanite), quartz-muscovite schist, quartzmagnetite-cummingtonite schist, fuchsite quartzite, banded calcgneiss, and layered and massive to schistose amphibolites (Saha, 1994). The stratigraphic relation between the different litho-units cannot be established because of the detached nature of the outcrops.

From a consideration of the immobile elements concentration in the OMG calc-silicate rocks Saha et al. (2012b) came to the conclusion that they were possibly formed by the alteration of mafic-felsic volcanic rocks of the type found in the oldest Iron Ore Group sequence in the Tomka-Daitari area. On the basis of the major element and trace element composition of the OMG biotite-muscovite schists Hofmann and Mazumder (2015) concluded that the protolith was siltstone or greywacke and the composition was similar to that of Archean greywackes and shales such as those of the Fig Tree Chert of the Barberton greenstone belt. The schists contain detrital zircon grains suggesting granitic or granite-derived sedimentary provenance of the metasediments. The REE pattern of the OMG quartzite shows high LREE enrichment with a small negative Eu anomaly and low HREE abundances, similar to that of the associated tonalite gneisses (Fig. 3a) (Nelson et al., 2014). This is suggestive of their derivation from principally granitoid rocks. Relatively high $\mathrm{Cr}, \mathrm{Ni}$ and $\mathrm{Mg}$ content in some schists and fuchsite quartzite suggest presence of mafic/ultramafic material also in the source area (Hofmann and Mazumder, 2015). The quartz-cummingtonite schist possibly represents an iron formation (Ray et al., 1987). The layered amphibolites (? paraamphibolite) have been interpreted by Saha et al., (1984) and Ray et al., (1991) to be metamorphosed chloritic sediments derived from the weathering of older low-potash-tholeiite (LKT-type mafic rocks). The massive to schistose amphibolites (orthoamphibolite) have a tholeiitic affinity (LKT), but it is not certain 
Table 1. Geochronological data from the Singhbhum Craton

\begin{tabular}{|c|c|c|c|c|}
\hline Material & Age (Ma) & Method & Reference & Remarks \\
\hline \multicolumn{5}{|c|}{ OMTG } \\
\hline \multirow[t]{2}{*}{ Tonalite, Champua } & $3288+35$ & WR Pb-Pb isochron, TIMS & \multirow[t]{2}{*}{ Moorbath et al., 1986} & \\
\hline & $3280 \pm 130$ & WR Rb-Sr isochron & & \\
\hline $\begin{array}{l}\text { Tonalite, } \\
\text { Champua }\end{array}$ & $3664 \pm 79$ & \multirow[t]{2}{*}{ WR Pb-Pb isochron } & \multirow[t]{2}{*}{ Ghosh et al., 1996} & $\begin{array}{l}\text { Samples from same locality as } \\
\text { Moorbath et al., } 1986\end{array}$ \\
\hline Tonalite, Onlajori & $3405 \pm 53$ & & & \\
\hline Tonalite, Champua & $3135 \pm 85$ & \multirow[t]{2}{*}{ WR Rb-Sr isochron } & \multirow[t]{2}{*}{ Sarkar et al., 1979} & \multirow{2}{*}{$\begin{array}{l}\text { Same set of samples as Ghosh } \\
\text { et al., } 1996\end{array}$} \\
\hline Tonalite, Onlajori & $3113 \pm 85$ & & & \\
\hline \multirow{2}{*}{$\begin{array}{l}\text { Zircon from } \\
\text { tonalite gneiss }\end{array}$} & $\sim 3.4 \mathrm{Ga}$ & \multirow{2}{*}{$\begin{array}{l}{ }^{207} \mathrm{~Pb} /{ }^{206} \mathrm{~Pb} \text { Small ion } \\
\text { microprobe }\end{array}$} & \multirow[t]{2}{*}{ Misra, 1999} & Formation of OMTG \\
\hline & $\sim 3.2 \mathrm{Ga}$ & & & Metamorphism age \\
\hline \multirow{2}{*}{$\begin{array}{l}\text { Zircon from } \\
\text { Haludpukur tonalite }\end{array}$} & $3448 \pm 19$ & \multirow[t]{2}{*}{ LA-ICP-MS } & \multirow[t]{2}{*}{ Acharyya et al., 2010a } & \multirow[t]{2}{*}{ Upper intercept age } \\
\hline & $3527 \pm 17$ & & & \\
\hline Monazite in tonalite & $3306+22$ & CHIME, EPMA & $\begin{array}{l}\text { Prabhakar and } \\
\text { Bhattacharya, } 2013\end{array}$ & Metamorphism age \\
\hline $\begin{array}{l}\text { Zircon in tonalite } \\
\text { intrusive into BIF }\end{array}$ & $3380 \pm 11$ & \multirow[t]{2}{*}{ SHRIMP } & \multirow[t]{2}{*}{ Nelson et al., 2014} & Concordia age \\
\hline $\begin{array}{l}\text { Zircon in tonalite, } \\
\text { Champua }\end{array}$ & $3331 \pm 9$ & & & Concordant age \\
\hline \multirow{4}{*}{$\begin{array}{l}\text { Zircon in } \\
\text { tonalite- } \\
\text { trondhjemite } \\
\text { suite, Champua }\end{array}$} & $3437 \pm 23$ & \multirow[t]{4}{*}{ LA-ICP-MS } & \multirow[t]{4}{*}{ Upadhyay et al., 2014} & Crystallization age \\
\hline & $3293 \pm 12$ & & & Main metamorphism \\
\hline & $3194+24$ & & & \multirow[t]{2}{*}{ Fluid activity } \\
\hline & $2965 \pm 86$ & & & \\
\hline \multirow{6}{*}{$\begin{array}{l}\text { OMTG granite, } \\
\text { Champua }\end{array}$} & $3611 \pm 11$ & \multirow[t]{6}{*}{ LA-ICP-MS } & \multirow[t]{6}{*}{ Upadhyay et al., 2014} & \multirow[t]{2}{*}{ Xenocryst core } \\
\hline & $3415 \pm 9$ & & & \\
\hline & $3318 \pm 3$ & & & Crystallization age \\
\hline & $2953 \pm 41$ & & & Later reequilibration events \\
\hline & $\sim 2450$ & & & \\
\hline & $\sim 1100$ & & & \\
\hline $\begin{array}{l}\text { Zircon in tonalite } \\
\text { enclave }\end{array}$ & $3471 \pm 24$ & LA-ICP-MS & Dey et al., 2017 & Upper intercept age, concordant \\
\hline Zircon Xenocryst & $4.24-4.03 \mathrm{Ga}$ & SHRIMP & Chaudhuri et al.2018 & Concordant age \\
\hline $\begin{array}{l}\text { Oscillatory zoned } \\
\text { rim of xenocryst }\end{array}$ & $3.9-3.8 \mathrm{Ga}$ & & & Discordant age \\
\hline Xenocryst & $3.67-3.59 \mathrm{Ga}$ & & & Concordant age \\
\hline $\begin{array}{l}\text { Oscillatory } \\
\text { zoning, euhedral }\end{array}$ & $3393 \pm 9,3399 \pm 6$ & & & $\begin{array}{l}\text { Upper intercept, Crystallization } \\
\text { age of OMTG }\end{array}$ \\
\hline Zircon in & $3352 \pm 13,3363 \pm 12$ & LA-ICP-MS & Pandey et al., 2019 & Concordant crystallization age \\
\hline trondhjemite & $3440 \pm 37$ & & & Concordant xenocryst age \\
\hline Zircon in granite & $3286+11$ & & & Concordant crystallization age \\
\hline & $3472 \pm 57$ & & & Concordant, xenocryst \\
\hline & & Singhbhum Gr & Phase I & \\
\hline Zircon in granite & $3350 \pm 20$ & LA-ICP-MS & Upadhyay et al., 2014 & Crystallization age \\
\hline & $3262 \pm 12$ & & & Relatively high grade \\
\hline & $\begin{array}{c}3165 \pm 17,3015 \pm 16 \\
2790 \pm 27,2521 \pm 44\end{array}$ & & & $\begin{array}{l}\text { Low grade fluid-induced } \\
\text { metamorphism }\end{array}$ \\
\hline Zircon & $\begin{array}{l}3397 \pm 9,3267 \pm 6 \\
3289 \pm 10\end{array}$ & SHRIMP & Chaudhury et al., 2018 & Upper Intercept, concordant \\
\hline
\end{tabular}


Table 1. Contd. ...

\begin{tabular}{|c|c|c|c|c|}
\hline Material & Age (Ma) & Method & Reference & Remarks \\
\hline \multicolumn{5}{|c|}{ Singhbhum Granite Phase II } \\
\hline Granitoid rocks & $3292 \pm 51$ & WR Pb-Pb isochron, TIMS & Moorbath and Taylor, 1988 & \\
\hline $\begin{array}{l}\text { Samples from } \\
\text { Besoi pluton }\end{array}$ & $3442 \pm 26$ & \multirow[t]{2}{*}{ WR Pb-Pb isochron, TIMS } & \multirow[t]{2}{*}{ Ghosh et al., 1996} & \\
\hline $\begin{array}{l}\text { Keonjhar- } \\
\text { Bhaunra pluton }\end{array}$ & $3298 \pm 63$ & & & \\
\hline $\begin{array}{l}\text { Zircon from } \\
\text { Keonjhar- } \\
\text { Bhaunra pluton }\end{array}$ & $3280 \pm 7$ & $\begin{array}{l}{ }^{207} \mathrm{~Pb} /{ }^{206} \mathrm{~Pb} \\
\text { Small ion microprobe }\end{array}$ & Misra, 1999 & \\
\hline \multirow{2}{*}{$\begin{array}{l}\text { Zircon from } \\
\text { Keonjhar- } \\
\text { Bhaunra pluton }\end{array}$} & $3291 \pm 9$ & \multirow[t]{2}{*}{ SHRIMP } & \multirow[t]{2}{*}{ Tait et al., 2011} & Concordant age \\
\hline & $3496 \pm 5$ & & & Inherited zircon (subhedral) age \\
\hline Zircon in monzogranite & $3326 \pm 5$ & SHRIMP & Nelson et al., 2014 & Near Rairangpur, Concordant age \\
\hline \multirow{4}{*}{$\begin{array}{l}\text { Zircon in granite } \\
\text { and trondhjemite }\end{array}$} & $3336 \pm 4$ & \multirow[t]{4}{*}{ LA-ICP-MS } & \multirow[t]{4}{*}{ Upadhyay et al., 2014} & Crystallization age \\
\hline & $3463+\underline{+8}$ & & & Xenocrystic core \\
\hline & $3281 \pm 4$ & & & Metamorphism \\
\hline & $3163 \pm 9$ & & & Low grade metamorphism \\
\hline $\begin{array}{l}\text { Zircon in porphyritic } \\
\text { granite of Keonjhar- } \\
\text { Bhaunra pluton }\end{array}$ & $3308 \pm 31$ & LA-MC-ICPMS & Dey et al., 2017 & \\
\hline $\begin{array}{l}\text { Zircon in } \\
\text { trondhjemite }\end{array}$ & $3334+15$ & \multirow[t]{2}{*}{ LA-ICP-MS } & \multirow[t]{2}{*}{ Pandey et al. 2019} & \multirow[t]{2}{*}{ Concordant, Crystallization ages } \\
\hline Zircon in granite & $3330 \pm 9$ & & & \\
\hline
\end{tabular}

Singhbhum Granite Phase III

\begin{tabular}{|c|c|c|c|c|}
\hline Jorapokhor pluton & $3050 \pm 37$ & WR Pb-Pb isochron, TIMS & Ghosh et al., 1996 & \\
\hline \multirow{2}{*}{$\begin{array}{l}\text { Zircon in } \\
\text { granodiorite }\end{array}$} & $3332 \pm 5$ & \multirow[t]{4}{*}{ SHRIMP } & \multirow[t]{4}{*}{ Nelson et al., 2014} & West of Gorumahishani \\
\hline & $3368 \pm 7$ & & & Xenocryst from same sample \\
\hline Zircon in granodiorite & $3299 \pm 7$ & & & East of Keonjhar \\
\hline $\begin{array}{l}\text { Zircon in pegmatitic } \\
\text { granodiorite }\end{array}$ & $3285 \pm 7$ & & & North of Seraikela, Concordant age \\
\hline \multirow[t]{3}{*}{ Zircon in granite } & $3445+4$ & \multirow[t]{3}{*}{ LA-ICP-MS } & \multirow[t]{3}{*}{ Upadhyay et al., 2014} & Crystallization age \\
\hline & $3347 \pm 8$ & & & Metamorphism \\
\hline & $3128 \pm 42,2962 \pm 33$ & & & Fluid mediated alteration \\
\hline \multirow{2}{*}{$\begin{array}{l}\text { Zircon in } \\
\text { nonporphyritic } \\
\text { granite }\end{array}$} & $3308 \pm 31$ & \multirow[t]{2}{*}{ LA-MC-ICPMS } & \multirow[t]{2}{*}{ Dey et al., 2017} & Upper intercept Crystallization age \\
\hline & $3304+25$ & & & Sub-concordant zircon \\
\hline Older Core & $3377 \pm 11,3367 \pm 7$ & \multirow[t]{2}{*}{ SHRIMP } & \multirow[t]{2}{*}{ Chaudhuri et al. 2018} & Concordant age \\
\hline Euhedral & $3286 \pm 6$ & & & Upper intercept \\
\hline \multirow{2}{*}{$\begin{array}{l}\text { Zircon in } \\
\text { trondhjemiteages }\end{array}$} & $3470 \pm 10$ & \multirow[t]{3}{*}{ LA-ICP-MS } & \multirow[t]{3}{*}{ Pandey et al. 2019} & \multirow[t]{3}{*}{ Concordia age, , Crystallization } \\
\hline & $3292 \pm 19$ & & & \\
\hline Zircon in granite & $3351 \pm 8$ & & & \\
\hline Zircon in granodiorite & $3300 \pm 7$ & SHRIMP & Olierook et al., 2019 & \\
\hline
\end{tabular}

Bonai Granite

\begin{tabular}{|l|c|l|l|l|}
\hline $\begin{array}{l}\text { Zircon in tonalite } \\
\text { xenolith }\end{array}$ & $3380 \pm 64$ & U-Pb, TIMS & Sengupta et al., 1996 & Discordant, Upper intercept age \\
\cline { 1 - 2 } Xenocryst & 3448 & & & Discordant, Upper intercept \\
\cline { 1 - 2 } Tonalite xenolith & $3369 \pm 57$ & WR Pb-Pb isochron & & Errorchron \\
\cline { 1 - 2 } & $3163 \pm 126$ & & \\
\hline
\end{tabular}


Table 1. Contd. ...

\begin{tabular}{|l|c|l|l|l|}
\hline Material & Age $(\mathrm{Ma})$ & Method & Reference & Remarks \\
\hline \multirow{3}{*}{ Zircon in granite } & $3370 \pm 10$ & LA-ICP-MS & Chakraborty et al., 2019 & Emplacement age \\
\cline { 2 - 4 } & $\begin{array}{c}3033 \pm 38,2809 \pm 29, \\
2531 \pm 22\end{array}$ & & & Metamorphic/hydrothermal ages \\
\hline
\end{tabular}

Tamperkola Granite

\begin{tabular}{|l|c|l|l|l|}
\hline \multirow{2}{*}{ Zircon in granite } & $2809 \pm 12$ & \multirow{2}{*}{$\begin{array}{l}{ }^{207} \mathrm{~Pb} /{ }^{206} \mathrm{PbSmall} \text { ion } \\
\text { microprobe }\end{array}$} & \multirow{2}{*}{ Bandyopadhyay et al., 2001} & Crystallization age \\
\cline { 2 - 2 } & $3391 \pm 8,3251 \pm 8$ & & Xenocrystic cores \\
\cline { 2 - 2 } Zircon in acid volcanics & $2822 \pm 67$ & & Volcanics related to granite \\
\hline
\end{tabular}

Kaptipada Granite

\begin{tabular}{|l|l|l|l|l|}
\hline & $3275 \pm 81$ & WR Rb-Sr isochron & Vohra et al., 1991 & Age of emplacement likely to be older \\
\hline
\end{tabular}

Mayurbhanj Grnite

\begin{tabular}{|c|c|c|c|c|}
\hline & $2084 \pm 70$ & WR Rb-SR isochron & Iyengar et al., 1981 & Ages likely to record later \\
\hline Samples from Nilgiri & $2366 \pm 126$ & \multirow[t]{2}{*}{ WR b-Sr isochron } & \multirow[t]{2}{*}{ Vohra et al., 1991} & 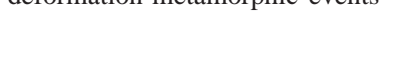 \\
\hline $\begin{array}{l}\text { Samples from } \\
\text { Romapahari }\end{array}$ & $1895 \pm 46$ & & & \\
\hline Zircon in granophyre & $\sim 2.8 \mathrm{Ga}$ & LA-ICP-MS & Acharyya et al., 2010a & $\begin{array}{l}\text { Discordant grains, upper intercept } \\
\text { of discordia curve }\end{array}$ \\
\hline Zircon in aplogranite & $3080 \pm 8,3092 \pm 5$ & $\begin{array}{l}{ }^{207} \mathrm{~Pb} /{ }^{206} \mathrm{PbSmall} \text { ion } \\
\text { microprobe }\end{array}$ & Misra et al., 1999 & \\
\hline $\begin{array}{l}\text { Zircon in gneissic } \\
\text { granite }\end{array}$ & $3089 \pm 6$ & La-ICP-Ms & Chakraborti et al., 2019 & Concordant age \\
\hline
\end{tabular}

Pallahara Gneiss

\begin{tabular}{|l|c|l|l|l|}
\hline \multirow{2}{*}{ Zircon in granite gneiss } & $2776 \pm 7$ & \multirow{2}{*}{ LA-SF-ICP-MS } & Chattopadhyay et al., 2015 & Concordant age, mantle \& core \\
\cline { 2 - 3 } & $2721 \pm 10$ & & Only mantle \\
\hline \multirow{2}{*}{ Zircon in gneiss } & $2792 \pm 75$ & LA-ICP-MS & Topno et al., 2018 & Upper intercept age \\
\cline { 2 - 5 } & $2788 \pm 59$ & & $\begin{array}{l}\text { Weighted average of most } \\
\text { concordant }{ }^{207} \mathrm{~Pb} /{ }^{206} \mathrm{~Pb} \text { ages }\end{array}$ \\
\hline
\end{tabular}

OMG

\begin{tabular}{|c|c|c|c|c|}
\hline \multirow{2}{*}{$\begin{array}{l}\text { Amphibole in } \\
\text { amphibolite }\end{array}$} & $3314 \pm 4$ & \multirow[t]{2}{*}{${ }^{40} \mathrm{Ar} /{ }^{39} \mathrm{Ar}$} & \multirow[t]{2}{*}{ Bakshi et al., 1987} & \multirow[t]{2}{*}{ Cooling age through $500^{\circ} \mathrm{C}$} \\
\hline & $3286 \pm 6$ & & & \\
\hline Amphibolite & $3305 \pm 60$ & \multirow[t]{2}{*}{ WR Sm-Nd isochron } & \multirow[t]{2}{*}{ Sharma et al., 1994} & Formation age \\
\hline Amhibolite \& Tonalite & $3288+35$ & & & Combined OMG-OMTG isochron \\
\hline \multirow{5}{*}{$\begin{array}{l}\text { Detrital zircon in } \\
\text { quartzite and quartz- } \\
\text { mica schist }\end{array}$} & $3551+13$ & \multirow{6}{*}{$\begin{array}{l}{ }^{207} \mathrm{~Pb} /{ }^{206} \mathrm{~Pb} \text { Small } \\
\text { ion microprobe }\end{array}$} & \multirow[t]{6}{*}{ Goswami et al., 1995} & Mean core age \\
\hline & $3583 \pm 25$ & & & Detrital grain \\
\hline & $3504+30$ & & & Detrital grain \\
\hline & $3628+38$ & & & Detrital grain \\
\hline & $3.43-3.38 \mathrm{Ga}$ & & & Detrital grains \\
\hline Zircon overgrowth & $\sim 3.2 \mathrm{Ga}$ & & & Metamorphism age \\
\hline \multirow[t]{3}{*}{ Detrital zircon } & $3504 \pm 30$ & \multirow{3}{*}{$\begin{array}{l}{ }^{207} \mathrm{~Pb} /{ }^{206} \mathrm{~Pb} \text { Small } \\
\text { ion microprobe }\end{array}$} & \multirow[t]{3}{*}{ Misra, 1999} & Round detrital \\
\hline & $3628+38$ & & & Round detrital \\
\hline & $3.43-3.38 \mathrm{Ga}$ & & & ? Metamorphic \\
\hline Zircon in schist & $3352 \pm 26$ & TIMS & Basu et al., 1996 & Pb-loss event \\
\hline Euhedral zircon & $3.35 \mathrm{Ga}$ & SHRIMP & Saha et al. ,2012b & Detrital/? Metamorphic grain \\
\hline \multirow{2}{*}{$\begin{array}{l}\text { Monazite in } \\
\text { mica schist }\end{array}$} & $3377 \pm 45$ & \multirow[t]{2}{*}{ CHIME, EPMA } & \multirow{2}{*}{$\begin{array}{l}\text { Prabhakar \& } \\
\text { Bhattacharya, } 2013\end{array}$} & \multirow[t]{2}{*}{ Metamorphism ages } \\
\hline & $3256 \pm 46$ & & & \\
\hline Zircon in qtzt. & $3375 \pm 3$ & SHRIMP & Nelson et al., 2014 & Concordant age Detrital grain \\
\hline Rutile in mica schist & $3317 \underline{+8}$ & LA-ICP-MS & Upadhyay et al., 2014 & Concordia age of metamorphism \\
\hline
\end{tabular}


Table 1. Contd. ...

\begin{tabular}{|c|c|c|c|c|}
\hline Material & Age (Ma) & Method & Reference & Remarks \\
\hline \multicolumn{5}{|c|}{ Iron Ore Group } \\
\hline Zircon in basal tuff & $3392 \pm 29$ & LA-ICP-MS & Basu et al., 2008 & Concordant age, Western BIF \\
\hline \multirow[t]{2}{*}{ Zircon in basal tuff } & $3507 \pm 2$ & LA-ICP-MS & Mukhopadhyay et al.,2008a & \multirow[t]{2}{*}{ Concordia age, Southern BIF } \\
\hline & $3505 \pm 5$ & LA-ICP-MS & Sreenivas et al., 2019 & \\
\hline \multicolumn{5}{|c|}{ Dhanjori Group } \\
\hline Metavolcanics & $2072 \pm 106$ & WR Sm-Nd TIMS & Roy et al., 2002 & $\begin{array}{l}\text { Samples close to shear zone, } \\
\text { isotopes likely to be disturbed }\end{array}$ \\
\hline \multirow[t]{2}{*}{ Metavolcanics } & $2787 \pm 270$ & WR Sm-Nd & \multirow[t]{2}{*}{ Misra and Johnson, 2005} & \\
\hline & $2794+210$ & WR Pb-Pb & & \\
\hline Zircon in basal acid tuff & $\begin{array}{c}3330 \pm 58 \text { and } \\
3358 \pm 110\end{array}$ & LA-ICP-MS & Acharyya et al., 2010b & $\begin{array}{l}\text { Discordant grains. Upper intercept } \\
\text { of discordia curve }\end{array}$ \\
\hline $\begin{array}{l}\text { Detrital zircon in basal } \\
\text { conglomerate }\end{array}$ & $\sim 3.04$ to $\sim 3.09$ & U-Th-Pb chemical age & Sunilkumar et al., 1996 & Age of provenance \\
\hline
\end{tabular}

\section{Younger Siliciclastic Rocks}

\begin{tabular}{|c|c|c|c|c|}
\hline $\begin{array}{l}\text { Detrital zircon, } \\
\text { Keonjhar Quartzite, } \\
\text { Mahagiri Quartzite }\end{array}$ & $\begin{array}{l}3584 \pm 7.1 \text { to } \\
3024 \pm 13\end{array}$ & LA-ICP-MS & Mukhopadhyay et al., 2014 & Concordant ages \\
\hline \multirow{3}{*}{$\begin{array}{l}\text { Detrital zircon in } \\
\text { Mahagiri Quartzite }\end{array}$} & $3950-2909$ & \multirow[t]{3}{*}{ SHRIMP and LA-ICP-MS } & \multirow[t]{3}{*}{ Sreenivas et al., 2019} & Entire Population Concordant ages \\
\hline & $3510-3176$ & & & $86 \%$ data \\
\hline & $\begin{array}{c}3438-3220 \\
\text { Peak } \sim 3.35 \mathrm{Ga}\end{array}$ & & & Dominant age Population \\
\hline
\end{tabular}

Malayagiri Belt

\begin{tabular}{|l|c|l|l|l|}
\hline $\begin{array}{l}\text { Zircon in dacite, } \\
\text { Malayagiri belt }\end{array}$ & $2806 \pm 6$ & Shrimp & Nelson et al., 2014 & \\
\hline $\begin{array}{l}\text { Detrital Zircon in } \\
\text { schist, Malayagiri }\end{array}$ & $2788 \pm 25$ & LA-ICP-MS & Chattopadhyay et al, 2015 & Youngest age of detrital zircon \\
\hline
\end{tabular}

Ultramafic suite

\begin{tabular}{|l|c|l|l|l|}
\hline $\begin{array}{l}\text { Gabbroic suite, } \\
\text { Baula, Nuasahi }\end{array}$ & $\begin{array}{c}3123 \pm 7,3119 \pm 6, \\
3122 \pm 5\end{array}$ & SHRIMP & Auge et al., 2003 & Concordant ages \\
\hline
\end{tabular}

\begin{tabular}{|c|c|c|c|c|}
\hline \multicolumn{5}{|c|}{ Newer Dolerite } \\
\hline $\begin{array}{l}\text { Ultramafic dyke } \\
\text { NNE'ly trend }\end{array}$ & $2613 \pm 177$ & WR Rb-Sr isochron & Roy et al., 2004 & \\
\hline $\begin{array}{l}\text { Dolerite dyke } \\
\text { WNW'ly tren }\end{array}$ & $1766 \pm 1,1765 \pm 1$ & TIMS & Shankar et al., 2014 & $\begin{array}{l}{ }^{207} \mathrm{~Pb} /{ }^{206} \mathrm{~Pb} \text { age from } \\
\text { baddeleyiteWeighted Mean age }\end{array}$ \\
\hline $\begin{array}{l}\text { Dolerite dyke } \\
\text { NNEly trend }\end{array}$ & $\begin{array}{c}2762 \pm 2 \\
2800.2 \pm 0.7\end{array}$ & TIMS & Kumar et al., 2017 & \\
\hline $\begin{array}{l}\text { Dolerite dyke NE'ly } \\
\text { to ENE'ly trend }\end{array}$ & $2256 \pm 6$ & TIMS & Srivastava et sal., 2019 & $\begin{array}{l}\text { Upper intercept age from } \\
\text { baddeleyite }\end{array}$ \\
\hline \multicolumn{5}{|c|}{ River Sands } \\
\hline \multirow[t]{4}{*}{ Detrital zircon } & $4015+9$ & \multirow[t]{4}{*}{ LA-ICP-MS } & \multirow[t]{4}{*}{ Miller, 2018} & 1 grain \\
\hline & $3.62-3.55 \mathrm{Ga}$ & & & $5 \%$ data \\
\hline & $3.50-3.22 \mathrm{Ga}$ & & & $87 \%$ data \\
\hline & $3.10-3.06$ & & & $6 \%$ data \\
\hline
\end{tabular}


whether they were originally volcanic or intrusive. The two types of amphibolites are intimately associated with one another and Hofmann and Mazumder (2015) suggested that the two may have a common origin. Thus a sedimentary origin for the layered amphibolite may not hold true. Slight differences in chemical compositions of the two types may be a result of secondary processes and/or difference in protolith chemistry. Sm-Nd isotopic studies (Sharma et al., 1994) yield a $\varepsilon_{\mathrm{Nd}(\mathrm{t})}$ value of $+0.9 \pm 0.7$ which indicates that the amphibolites came from a mantle source slightly depleted in terms of Nd-isotopes. No komatiite has been reported so far from the OMG, but from the Jagannathpur area Manikyamba et al. (2015) have reported boninitic affinity of some mafic rocks; these are associated with island arc tholeiites. The authors invoke magma generation in an intra-oceanic subduction zone setting and infer a depleted, refractory mantle source that has been subsequently enriched by subduction-related slabdehydration process. The rock association and the geochemical signatures suggest that the OMG outcrops represent fragments of the Archean oceanic crust, probably in an ancient (Paleoarchean) subduction system similar to, but younger than, those recorded from the Nuvvuagittuq Greenstone Belt of Canada (O’Neil et al., 2012) and Isua Greenstone Belt of Greenland (Polat et al., 2002, 2011).

The regional structure of the OMG rocks is not very clear because of the paucity of structural data. Prabhakar and Bhattacharya (2013) report that the most prominent fabric in the schists is a differentiated crenulation cleavage with alternate quartz-rich and mica-rich bands and intrafolial folds on earlier schistosity. They invoke the presence of a $0.5 \mathrm{~km}$ wide steep-dipping ductile shear zone, named as the Champua Shear Zone (CSZ) with steep plunging movement direction along the eastern edge of the OMG outcrop near Champua.

Prabhakar and Bhattacharya (2013) have described that the premylonitization metamorphism was of middle amphibolite facies $\left(600^{\circ} \mathrm{C}-650^{\circ} \mathrm{C}\right)$, and the later syn-shearing metamorphism was of greenschist facies $\left(<500^{\circ} \mathrm{C}\right)$. Saha et al. (2012a and b) have recorded the assemblage garnet-clinopyroxene-quartz in the OMG amphibolite. From constructed pseudosections they have estimated the P-T conditions to be $\sim 15.5-16.5 \mathrm{~kb}, 600-650^{\circ} \mathrm{C}$, corresponding to a geothermal gradient of $\sim 15^{\circ} \mathrm{C} / \mathrm{km}$ that is comparable to the average shallow shield gradient (Winter, 2010). From this preliminary study they remarked that the P-T conditions indicate that tectonic processes leading to crustal thickening were operative in the Archean times in the Singhbhum Craton. Further work is necessary to explore this aspect thoroughly.

The OMG was considered to be the oldest stratigraphic unit of the craton (Saha, 1994). The geochronological data are given in Table 1 and Figure 4. It is to be noted that a spectrum of ages is normally expected in a population of detrital zircon grains, and a unimodal distribution of detrital zircon age as reported by Saha et al. (2012b) and Nelson et al. (2014) (Table 1) is unusual and would suggest either a volcaniclastic origin of the rock or derivation by erosion of a single igneous source (Saha et al., 2012b). Unfortunately, the authors have not described the detailed morphology of the grains, nor have given any photomicrographs of the grains. The available age data from detrital zircon grains and whole-rock Sm-Nd isochron indicate that the deposition of the supracrustal rocks may be bracketed within $\sim 3.37$ - 3.35 Ga (Fig. 4). U-Pb study of euhedral zircons from OMG pelitic schist by Basu et al. (1996) have yielded discordant data, from which they have inferred that the first lead loss event (?during metamorphism) affected the older zircons at 3352 \pm 26 Ma. CHIME (Chemical U-Th-total $\mathrm{Pb}$ isochron dating method) ages of metamorphic monazites overgrowing tectonic fabrics cluster in two populations with mean ages of $3377 \pm 45 \mathrm{Ma}$ and $3256 \pm 46 \mathrm{Ma}$ (Prabhakar and Bhattacharya, 2013) signifying two episodes of metamorphism affecting the OMG. U-Pb concordia age from metamorphic rutile in OMG mica schist fixes the metamorphic age as $3317 \pm 8$ Ma (Upadhyay et al., 2014). Therefore, the dates of the metamorphic events are $\sim 3.37-3.35,3.31-3.30$ Ga and $\sim 3.28-3.25$ Ga. Thus not much time elapsed between the deposition/formation and the earliest metamorphism.

The OMG supracrustal assemblage was probably formed as a greenstone belt-type succession in a supra-subduction setting at $\sim 3.37$ $\mathrm{Ga}$, and it has been suggested that they represent the higher grade equivalents of the Iron Ore Group of rocks (Hofmann and Mazumder, 2015).

\section{Iron Ore Group (IOG)}

The Archean volcano-sedimentary greenschist facies supracrustal rocks of the SC, conventionally going by the name Iron Ore Group (IOG), are considered as truncated ophiolitic sequences and segments of the Archean oceanic crust by some workers (Acharyya, 1993). These occur either as peripheral basins around the Singhbhum Granite batholithic complex or as keels within it (Fig. 1). The stratigraphic relation between the SBG and the IOG has long been a point of debate (Mukhopadhyay, 1976, 2001; Sarkar and Saha, 1977; Saha, 1994). Evidence of older age of the IOG with respect to at least some components of the SBG and the BG come in the form of enclaves of BIF, cherts and associated mafic rocks within the SBG and the BG (Dey, 1991; Paul et al., 1991; Saha, 1994; Sengupta et al., 1996; Jena and Behera, 2000), and intrusive relation of the SBG with the mafic rocks of the IOG, e.g. from Mailum Ghati near Gorumahisani (Dunn and Dey, 1942). On the other hand, the main reason for assigning a younger age to the IOG is the interpretation of a sandstoneconglomerate unit unconformably overlying the SBG as being the basal unit of the IOG (Murty and Acharya, 1975; Mukhopadhyay, 1976). However, recent work by Ghosh et al. (2015, 2016b) and Mukhopadhyay et al. (2007, 2013, 2014, 2016) have shown that the siliciclastic rocks along the eastern margin of the western IOG belt and along the southern and southeastern magin of the southern IOG belt belong to an younger formation and do not constitute the basal unit of the IOG. Similarly, the conglomerate horizon at Sulaipat in the eastern IOG belt contains pebbles of black chert and BIF, and hence must be younger than the IOG. Recent geochronological data have confirmed the antiquity of the IOG belts. The $3380 \pm 11 \mathrm{Ma}$ age of the granite intruding the IOG at the Deo River (Nelson et al., 2014) stipulates that the BIF of the western belt cannot be younger than $\sim 3.38 \mathrm{Ga}$. The age of the monzogranite near Rairangpur (3326+5 Ma, Nelson et al., 2014) with enclaves of BIF also fixes a lower limit of the age ( $>\sim 3.3 \mathrm{Ga}$ ) of the eastern IOG. Zircon grains from a tuff layer less than $1 \mathrm{~m}$ below the BIF of the western belt yield concordant age of 3392 $\pm 29 \mathrm{Ma}$ (Basu et al., 2008). Zircon grains from a dacitic lava immediately underlying the BIF of the southern belt (TomkaDaitari) conformably yield concordia ages of 3507+2 Ma and 3505 \pm 5 Ma (Mukhopadhyay et al., 2008c, 2012; Sreenivas et al., 2019) Therefore, the deposition of the IOG supracrustals is as old as $~ 3.5-$ $3.4 \mathrm{Ga}$ and is of the same order as or older than the age of the OMG supracrustals.

There are three principal volcano-sedimentary supracrustal belts, also known as the IOG basins, which are: the western IOG belt 
(Noamundi-Jamda-Koira belt), the eastern IOG belt (GorumahisaniBadampahar belt) and the southern IOG belt (Tomka-Daitari belt) (Fig. 1). Some consider that the three principal BIF-bearing supracrustal assemblages belong to a single stratigraphic unit, the Iron Ore Group (IOG) (Dunn, 1940; Dunn and Dey, 1942; Sarkar and Saha, 1977, 1983; Acharyya, 1993; Saha, 1994), while others (Prasada Rao et al., 1964; Banerji, 1977, Banerjee, 1982; Iyengar and Murthy, 1982; Acharya, 1984) hold that they are of different ages; the latter subdivide the rocks into older and younger IOG successions. The stratigraphic status of the BIF-bearing Malayagiri belt (Fig. 1) is discussed later.

\section{Banded Iron Formation}

It is probable that the IOG sequences were deposited in separate basins, which had somewhat different depositional settings, and probably had slight differences in depositional age. There are some differences in the mineralogy, geochemistry and lithological association of the BIFs in the different belts, particularly between the western and the eastern belts (Acharya, 1984; Chakraborty and Majumder, 1986). BIFs are more magnetite-rich in the eastern and the southern basins than in the western one. The differences between the three IOG basins have been summarized by Sarkar and Gupta (2012).

The eastern IOG belt is lithologically complex; the generalized lithostratigraphic succession comprises of basal mafic-ultramafic and acid-to-intermediate volcanic units overlain by recrystallized chert, BIF and phyllites (Mukhopadhyay et al., 2008a, b). Enveloping granitoids of the Singhbhum Granite pluton have intrusive or tectonic contacts with the supracrustal assemblage. Locally grunerite has developed in the banded ferruginous quartzite.

In the western IOG belt the basal massive or pillowed metabasalt is followed upwards successively by chert breccias, lower phyllitic ferruginous shale/tuff (with local thin carbonates and manganiferous units in the lower part), BIF-iron ore, and upper phyllitic shale that is ferruginous or white (Ghosh and Mukhopadhyay, 2007; Beukes et al., 2008). The chert breccia overlying the mafic lavas indicates falling sea level and aerial exposure. Structures resembling stromatolites in some of the chert clasts suggest that the breccias could have formed through solution collapse and silicification of an earlier carbonate buildup during exposure. This solution collapse breccia is overlain by a transgressive shale unit with manganiferous shale being deposited in the early stages of transgression or during low strand, which is overlain by ferruginous shale. Iron formation was deposited on top of it during maximum flooding when the basin became starved of siliciclastic input. Further work on sequence stratigraphy in all the Iron Ore Basins is needed.

The BIFs of SC are dominantly of oxide facies; silicate facies is additionally present in the eastern belt. Carbonates are rare in the Iron Ore Basins; siliceous dolomite with stromatolitic structures have been noted at a few places within the western belt (Saha, 1994). Bhattacharya et al. (2007) remarked that low $\mathrm{Al}_{2} \mathrm{O}_{3}$ content attests the detritus-free nature of the silica-iron chemical precipitate. PAASnormalized REE plots show conspicuous HREE enrichment. Trace and REE patterns with strong Eu anomalies of the iron oxide phases of the BIFs suggest exhalative hydrothermal fluids with variable, but overall high, temperatures as source for the major part of the Fe; other trace elements and REEs were contributed to the bottom seawater by diagenetic fluids and fluvial discharge to the ocean. Variable Eu anomalies in the samples indicate mixing of hydrothermal fluids of different temperatures with the bottom seawater. Insignificant Ce anomaly is attributed to anoxic nature of the Archean bottom sea water (Bhattacharya et al., 2007). The supply of Fe was through seafloor hydrothermal leaching and possibly exhalation (Jacobsen and Piemental-Klose, 1988; Klein, 2005; Nadoll, et al., 2014). Microbial activity probably played a part in the oxidation and precipitation of iron-oxide (Beukes and Klein, 1992; Beukes, 2004; Kappler et al., 2005; Bekker, 2010).

The BIF is the protolith of high grade iron ore which are supergene-modified hydrothermal deposits (Mukhopadhyay et al., 2008b). Data from the Noamundi deposit in the western IOG show that the REE pattern of the ore body is similar to that of the parent BIF (Beukes et al., 2008). They have low REE abundances with depleted LREE and relatively enriched HREE with positive Eu anomaly. The core of many ore bodies is made up of massive or laminated martite (after magnetite) and microplaty hematite-martite is marginal to the martite dominated core. $\delta^{18} \mathrm{O}$ (relative to Standard Mean Ocean Water) for martite range from -2.6 to $-6.7 \%$, that for microplaty hematite is -1.3 to $-2.6 \%$ (Gutzmer et al., 2006). Values for partly mineralized BIF overlap with those for martite. From these observations Beukes et al. (2008) have presented the following model: hypogene hydrothermal fluid ( $\mathrm{Fe}^{+2}$ carrying, warm and reducing) replaced BIF to produce massive magnetite (martite) mineralization at deeper levels and microplaty hematite formed at shallower level due to cooling and/or oxygenation of the hydrothermal solutions. These were modified by later supergene processes. In contrast to the Noamundi ores the $\delta^{18} \mathrm{O}$ values for magnetite ores of the eastern IOG belt range from +0.8 to $+7.2 \%$ (Mukhopadhyay et al., 2008c). Cogenetic occurrence of magnetite, kerogen and trace sulphides point to mildly reducing hydrothermal fluid, rather than an oxidizing fluid as at Noamundi. The presence of kerogen suggests low to moderate temperatures and favours a shallow crustal fluid source. It has been suggested (Mukhopadhyay et al., 2008c) that the magnetite deposits may represent an intermediate stage and martitization of the magnetite ores may give rise to hard hematite-martite ores. However, the presence of two contrasted ore-types within the same craton is intriguing, and what factors were responsible to make the hydrothermal fluids oxidizing or mildly reducing remain unclear and need to be further investigated. In this context it may be mentioned that the $\delta^{18} \mathrm{O}$ values for greenstone lava $($ mean $=+6.8 \%$ ) and shale $($ mean $=+14.3$ $\%$ ) exhibit similar ranges as the Phanerozic equivalent rock types (Banerjee et al., 2008). The $\delta^{18} \mathrm{O}$ values of coexisting secondary amphibole $\left(+1.6 \leq \delta^{18} \mathrm{O} \leq+7.3 \%\right)$ and feldspar $\left(+3.8 \leq \delta^{18} \mathrm{O} \leq+11.8\right.$ $\%$ ) from lava samples also exhibit variability analogous to modern sea floor hydrothermal rocks. The oxygen isotope data from the IOG greenstone lava and shale samples support the idea of ${ }^{18} \mathrm{O}$-shifted nature of the Archean Ocean Water $\left(\delta^{18} \mathrm{O}>0 \%\right.$ ); the Archean Ocean was not ${ }^{18} \mathrm{O}$-depleted.

The overall structural trend in the different IOG supracrustal belts curve round the Singhbhum Granite body, suggesting that the major deformation in the supracrustal belts was moulded round the granitic block (Mukhopadhyay, 1976; Sarkar and Gupta, 2012) . The eastern belt probably represents a subvertical synformal keel within a granitic terrane. The BIF of the western belt is interpreted to have been folded into a major synclinorium, giving rise to the horseshoe shaped outcrop (Dunn, 1940; Sarkar and Saha, 1962). It is overturned to the east and has gentle northerly plunge (Saha, 1994). Ghosh and Mukhopadhyay (2007) concluded that two phases of deformation have given rise to 
the outcrop pattern in the 'horse-shoe' structure. We present here a slightly modified interpretation based on the map (Fig. 6a) and structural data of Ghosh and Mukhopadhyay (2007), Ghosh et al. (2010b) and Mukhopadhyay et al. (2008b). The first deformation produced a major overturned synform (the western syncline of Ghosh and Mukhopadhyay, 2007) whose western limb is overturned and steep westerly dipping and the eastern limb is gently westerly dipping. On the eastern limb a second order asymmetrical fold pair congruous to the major synform is developed. On the subhorizontal short limb of this asymmetric fold pair (their eastern asymmetric anticline) third order symmetrical folds with subvertical axial planes are developed (Fig. 6b). The flat folded part is exposed in the Noamundi, Joda and Malangtoli areas. In the core region of the main synform, exposed in the Jamda-Koira valley, a number of lensoid inliers of BIF arranged en echelon within the Upper Shales (Fig. 6a) represent domal structures produced by superposition of second generation antiforms on second order first generation antiforms. A major longitudinal fault along the eastern limb has brought the Lower Shale in contact with the Upper Shale. E-W faults cutting across the fold structures are likely to represent brittle accommodation structures during the second phase of deformation. Ghosh et al. (2010b) studied the anisotropy of magnetic susceptibility (AMS) of the basal metalava of the IOG of the western basin and identified two consistent magnetic fabrics which are correlated with the $\mathrm{D}_{1}$ and $\mathrm{D}_{2}$ deformations.

According to Ghosh et al. (2010a) and Bose et al. (2015) in the rocks in the southern IOG belt the first and second generation folds are co-axial and have E-W trending axial planes while the third generation folds are N-S trending. First deformation is restricted within the Iron Ore Group while second deformation has affected both the Iron Ore Group and the younger Mahagiri Quartzite (described later). The $\mathrm{D}_{2}$ structures are thought to be related to the top-to-the-north motion along the Sukinda Thrust. Detailed structural information on the Tomka-Daitari belt is not available.

\section{IOG Metavolcanic Rocks}

The basal part of the supracrustal sequence in all the three IOG basins are mafic-ultramafic volcanics, often with well preserved pillow structures (Sengupta et al., 1997; Bose, 2009) and locally variolitic structures with phenocrysts of plagioclase and tremolite in a glassy matrix. The IOG volcanics often have high MgO (up to 13\%) with high $\mathrm{SiO}_{2}$ (up to 52\%) and some may be characterized as siliceous high magnesia basalt (SHMB). The mafic rocks in all the three IOG belts are mostly tholeiite, but basaltic andesite and andesite variants are also found. Rare ultramafic rocks with cumulate texture are present in all the three belts. The volcanics of the western belt have slightly fractionated REE pattern with negative Eu anomaly. The eastern belt rocks have almost flat REE patterns with slightly enriched LREEs and no significant Eu anomaly. The geochemical characteristics suggest the volcanics of the eastern and western belts to be petrogenetically somewhat different.

Komatiitic types with spinifex texture have been reported from several localities in the eastern belt (Acharyya, 1993; Sahu and Mukherjee, 2001; Chaudhuri et al., 2014; Ghosh et al., 2019). Both Al-depleted (ADK) and Al-undepleted komatiites (AUK) are present. The basal cumulate part of the komatiite is chemically similar to ADK which is characterized by subchondritic $\mathrm{Al}_{2} \mathrm{O}_{3} / \mathrm{TiO}_{2}$ (9.38-10.5) ratio and depleted HREE, elucidating presence of majorite in residuum. The upper spinifex-textured lava (AUK) typically displays

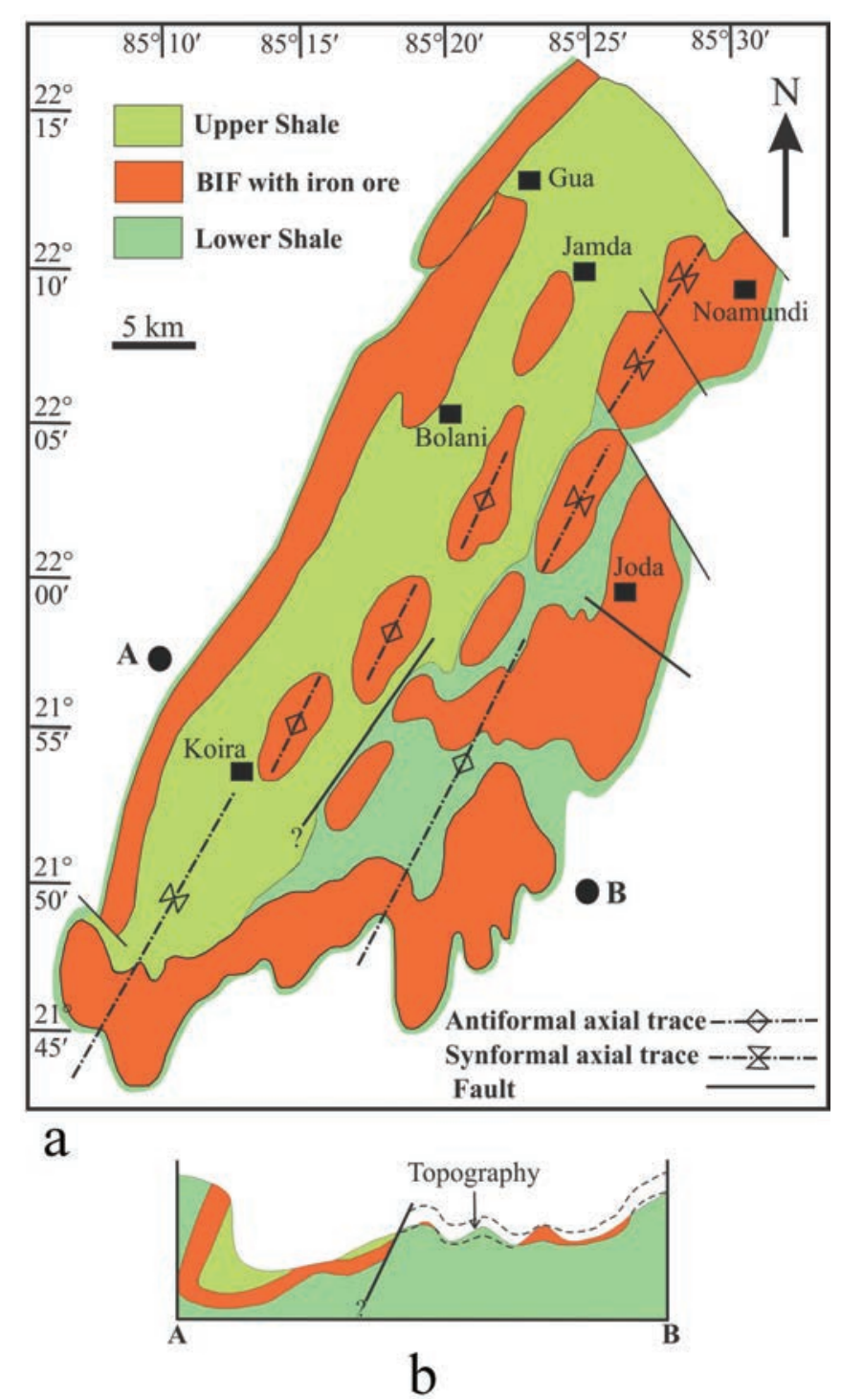

Figure 6. a. Generalized geological map of the western IOG. $b$. Schematic cross section along A-B (in Figure a). The cross section shows a regional syncline with a congruous dextral large scale fold on the eastern limb.

suprachondritic $\mathrm{Al}_{2} \mathrm{O}_{3} / \mathrm{TiO}_{2}$ ( 22-28.5) ratio and enriched HREE indicating majorite-free residuum. A primitive mantle-like source is envisaged, which melted at greater depth $(>300 \mathrm{~km})$ to produce the parental liquid of ADK (basal cumulate) and at shallower depth ( 150 $\mathrm{km})$ to produce the AUK melt (spinifex-textured lava). Komatiitic basalts were generated from AUK, and tholeiitic basalts were generated from evolved komatiitic basalts by assimilation and fractional crystallization processes (Chaudhuri et al., 2014; Ghosh et al., 2019). Sm-Nd isotopic studies suggest a mantle source with long term depletion $\left(\varepsilon_{\mathrm{Nd}}=\sim+2\right.$ to +4$)$. Intrusion of $3.3 \mathrm{Ga}$ granitoid belonging to the Singhbhum Granite suite into the eastern IOG belt (Sahu and Mukherjee, 2001; Nelson et al., 2014) suggests the emplacement of these komatiites to be earlier than $3.3 \mathrm{Ga}$. The similarity between the Singhbhum komatiite and Barberton komatiite has been pointed out and a plume-arc geodynamic setting has been suggested.

In the southern IOG belt the presence of calc-alkaline intermediate to felsic volcanic rocks, and basalts has been considered as a bimodal suite associated with bedded chert and formed in an arc setting 
(Mukhopadhyay et al., 2012). Some of the felsic volcanic rocks of the southern IOG basin are characterized by high $\mathrm{K}_{2} \mathrm{O}$ contents $(>5$ wt\%) with very low $\mathrm{Na}_{2} \mathrm{O}$ contents (0.29-0.41 wt\%) and highly fractionated REE patterns (Mukhopadhyay et al., 2012). The southerly dipping sequence has massive or pillowed metabasalt and interbanded chert in the basal part which is overlain by a thick unit of dacitic lava flows and pyroclastic rocks followed by BIF (Mukhopadhyay et al., 2008a, 2012). The southern contact of this supracrustal belt with the Sukinda ultramafic complex is tectonic. From lithological association and facies analysis of the dacitic volcanic unit (coherent dacitic flow and ash-poor, non-vesiculated, welded pyroclastics) in the southern IOG basin Mukhopadhyay et al. (2012) concluded that the volcanic succession was formed in a deep marine setting and erupted under a steam cupola. In the upper part of the volcanics there is evidence of transition from a deep water low-height volcanic chain to a shallower subaqueous eruption in an aggradational volcanic chain. This was followed by deposition of BIF. The bimodal volcanics association and the trace elements and REE characteristics of the volcanic units in the southern IOG are similar to the rocks in Phanerozoic suprasubduction arc-forearc settings (Mukhopadhyay et al., 2012).

The 3.5 Ga zircons from the dacitic lava in the southern IOG belt yield a $\varepsilon_{\mathrm{Hf}(\mathrm{t})}$ value of +0.5 to +7.8 (suprachondritic $\varepsilon_{\mathrm{Hf}(\mathrm{t})}$ and radiogenic Hf isotopic composition) and mostly plot close to the depleted mantle (DM) curve (Fig. 5), thereby indicating that by 3.5 Ga the depleted mantle was established under the Singhbhum Craton and was available for magma generation.

\section{Malangtoli and Jagannathpur Volcanics}

Contrasted views exist about the stratigraphic position of the Jagannathpur Volcanics (or Dungoaposi Volcanics) north of Noamundi and the Malangtoli Volcanics south of the horseshoe closure of BIF (Fig. 1). Some workers (Saha, 1994; Singh et al., 2016; Singh et al., 2017) regard these to be younger than the IOG and lying unconformably over the latter, while others regard them to be equivalent to the basal IOG mafic volcanics (Dunn, 1940; Acharyya, 1993; Sengupta et al., 1997). The Malangtoli Volcanics with subhorizontal primary layering underlies the gently folded BIF with an overall flat attitude (Sengupta et al., 1997), and the field relations confirm an infra-BIF position of the Malangtoli Volcanics. There are no direct radiometric dates from the Malangtoli Volcanics. Singh et al. $(2016,2017)$ made a comparative study of the IOG Volcanics near Noamundi and the Malangtoli Volcanics and pointed out that the IOG and the Malangtoli basalts exhibit similar mineralogical composition, but the IOG volcanics samples are andesitic with a calc-alkaline affinity while the Malangtoli Volcanics samples are basalt to andesite with tholeiitic to calc-alkaline trend. The Malangtoli Volcanics have both low-MgO and high-MgO varieties; some are boninitic in composition. Typical IOG basalts show enriched LREE and flat HREE and negative Eu-anomaly; some samples of the Malangtoli Volcanics show a similar REE pattern while others have nearly flat LREE and HREE (Singh et al., 2016, 2017). The IOG basalts show low to moderate PGE contents (26.23-68.35 ppb of $\Sigma$ PGE), whereas the Malangtoli basalts show a moderate to high concentration of PGE ( $\Sigma$ PGE $=43.01-190.43 \mathrm{ppb})$. The geochemical attributes point to a subduction-related origin for both. The IOG volcanics were generated in an intra-oceanic arc setting, while the Malangtoli Volcanics originated in an arc to rift-controlled back-arc setting. Arc basalts and boninites in the Malangtoli Volcanics are interpreted to be the products of juvenile subduction processes involving shallow level partial melting of mantle wedge under hydrous conditions triggered by slab-dehydrated fluid flux. High magnesian andesites and the Nbenriched basalts represent the intermediate and mature stages of subduction respectively (Singh et al., 2017) and slab-melting and mantle wedge hybridization processes were involved in their melt generation. The IOG volcanic rocks are modelled to have been derived by $<1-1 \%$ partial melting of garnet lherzolite whereas the Malangtoli basalts were generated by $3-<10 \%$ partial melting from spinel to garnet lherzolite. Banerjee et al. (2016), on the basis of tectonic discrimination diagrams, supported the idea that the Malangtoli Volcanics have island arc tholeiitic affinity and were erupted in a supra-subduction setting. Their experimental work suggests crystallization of the parental magma at temperatures ranging from $1500^{\circ} \mathrm{C}$ to $1200^{\circ} \mathrm{C}$.

The Jagannathpur Volcanics exposed near Noamundi along the eastern margin of the western IOG belt dips gently towards SW and show gentle dome-and-basin structures. Saha (1994) was of the view that they are Proterozoic in age and are to be correlated with the Dhanjori Volcanics; they were thought to have erupted in a continental setting. A large number of flows have been identified (Banerjee, 1982) and the rocks vary from basalt to andesite. Some of the volcanics resemble boninites with high $\mathrm{MgO}$, low $\mathrm{Ti} / \mathrm{Zr}$ and high $\mathrm{Zr} / \mathrm{Y}$. The Jagannathpur and Malangtoli Volcanics are apparently undeformed, but the AMS studies (Mukherji et al., 2004; Ghosh et al., 2010b;) reveal that they share the same magnetic fabric as the IOG mafic rocks and on this ground the three are correlated. Misra and Johnson (2005) report a whole rock $\mathrm{Pb}-\mathrm{Pb}$ isochron age of 2250+81 Ma for the Jagannathpur Volcanics. However, Roy and Sarkar (2006) have questioned this age data and recommended re-evaluation. Since the rocks have suffered weak metamorphism the significance of this age remains doubtful.

\section{Ongarbira Volcanics}

Ongarbira Volcanics crop out as a folded band with E-W axial trace. This fold appears to correspond to the easterly closure of a sheath fold having reclined geometry (Fig. 1) developed in the North Singhbhum Mobile Belt (NSMB) (Mukhopadhyay et al., 1990; Blackburn and Srivastava, 1994). It is bounded by tuffs and phyllites with uncertain stratigraphic status. In continuation of its southwestern termination is an isolated body of ultramafics, the Jojuhatu-Roro ultramafics, displaying similar structural pattern (Mukhopadhyay and Dutta, 1983). The Ongarbira Volcanics is made up of low-K tholeiite, ultramafic flows, tuffs, felsic lavas (alkali trachyte type) and gabbropyroxenite intrusive (Blackburn and Srivastava, 1994). The ultramafic lavas are picritic and the basalts are tholeiitic. Trace elements characteristics suggest that the basalts were generated in an extensional environment and they are similar to continental rift basalts but with oceanic affinities and were probably emplaced in a mature continental rift or in a back-arc basin.

Generally the Ongarbira Volcanics is shown as an integral part of the western IOG belt (e.g., Sarkar and Saha, 1983; Saha, 1994). However, structurally it has greater affinity to the NSMB. It has been suggested that the Ongarbira Volcanics and the Dalma Volcanics belong to the same structural horizon, but the continuity is lost because of attenuation and faulting on a limb of a regional fold (Mukhopadhyay et al., 1990; Blackburn and Srivastava, 1994). Thus the implication is that the boundary of the Singhbhum craton is to be drawn south of 
the Ongarbira Volcanics. Bose (2009) had also drawn attention to the compositional similarity of the Ongarbira Volcanics with the Dalma Volcanics and commented that in the absence of typical calc-alkaline character the Ongarbira Volcanics cannot be convincingly related to an island arc setting as suggested by Raza et al. (1995).

\section{Younger Supracrustal Rocks in the Singhbhum Craton}

\section{Dhanjori Group}

Dhanjori basin, situated in the north-eastern corner of the Singhbhum Craton (Fig. 1), is caught up in the Mesoproterozoic orogenic movement in the North Singhbhum Mobile Belt. The Dhanjori succession, predominantly consisting of volcanics and volcaniclastic and siliciclastic sediments, unconformably overlies the granitoids of the SBG pluton. It may be subdivided into Upper and Lower Formations (Gupta, 1985; Mazumder and Sarkar, 2004; De et al., 2015). The Lower Dhanjori Formation consists of pebbly phyllite, quartzite and thin conglomerates with minor mafic-ultramafic intrusions and the Upper Dhanjori Formation consists of volcanics and volcaniclastic rocks with some quartzites and phyllites. A basal gold and uranium bearing quartz-pebble conglomerate along with phyllites, acid volcanic rocks, acid and basic tuffs and mafic-ultramafic intrusives has been named as the Phuljhari Formation by Acharyya et al. (2010b). It disconformably underlies the polymictic conglomeratequartzite of the Lower Dhanjoris. The basal Dhanjoris are profusely intruded by the 3.1 Ga old Mayurbhanj Granite. Hence, at least the lower part of the Dhanjori Group is older than $~ 3.1 \mathrm{Ga}$.

Mazumder and Sarkar (2004) pointed out that the Dhanjori Formation is a terrestrial (dominantly fluvial) volcano-sedimentary succession deposited in an intracontinental rift basin. The lower part of the succession, consisting of basal conglomerate, coarse-grained sandstone, and shale resting on granitic basement, represents the distal fringe deposit of an alluvial fan complex. The second phase of Dhanjori sedimentation has profuse volcanics and associated volcaniclastic deposits, followed by sandstone, conglomerate and a heterolithic facies (Mazumder and Sarkar, 2004). A semi-arid paleoclimate during the fluvial deposition is also inferred. On the basis of sediment characteristics and Sm-Nd isotopic data De et al. (2015) suggested proximal sources and poorly mixed provenance with both mafic and felsic rocks. They further suggested a sedimentary provenance in a juvenile felsic Andean-type magmatic arc situated on the Archean basement.

Dhanjori Volcanics are mainly composed of basalt and basaltic andesite of tholeiitic series (Alvi and Raza, 1992) with subordinate picrite. The upper Dhanjori basaltic suite comprises alkali olivine basalts passing upwards into K-poor oceanic tholeiites, and at lower levels the high-magnesia vitric tuffs are mafic to ultramafic in composition. The REE plots show moderate to strong REE fractionation, moderate LREE enrichment, and low HREE fractionation (Roy et al., 2002; Mazumder and Arima, 2009). Ghosh and Ray (1994) proposed a back-arc setting for Dhanjori volcanism, while Alvi and Raza (1992) invoked an island-arc setting. Bose (2009) inferred extensional tectonics for the Dhanjori basin. Mazumder (2006) observed that the magmatic component of the Dhanjori Formation represents a Large Igneous Province (LIP), and Mazumder and Arima (2009), on the basis of major, trace, rare earth elements composition, and selected elemental ratios ( $\mathrm{Nb} / \mathrm{Th}, \mathrm{Zr} / \mathrm{Nb}, \mathrm{Nb} / \mathrm{Y}$, and $\mathrm{Zr} / \mathrm{Y}$ ) from the Upper Dhanjori volcanics and volcaniclastics and the sedimentological and stratigraphical characteristics of the interbanded metasedimentary rocks, inferred an intracontinental rift setting for Dhanjori volcanism and sedimentation. Deb (1999) suggested that the mode of eruption of the Dhanjori Volcanics was rhythmic with alternate effusive and explosive phases. Roy et al. (2002) on the basis of trace, REE, Rb-Sr and Sm-Nd isotope analyses suggested enriched mantle as the source of the Dhanjori Volcanics and characterized it as a plume magmatism manifested by the extrusion of komatiitic/basaltic flows and basic/ultrabasic intrusives. They further suggested that the enriched mantle material, part of a thermal plume, pierced through the deep fractures produced due to the cooling and readjustment of the stabilized Archean continental crust and ultimately erupted as the Dhanjori Volcanics. No depleted signature has been found and hence it is presumed that the plume was fed by recycled oceanic crust brought to the depth by subduction process operating during the IOG time. Alternatively, the enrichment could be due to contribution of delaminated continental crust at the source, though Roy et al. (2002) are not in favour of this hypothesis.

At the northern margin of the basin the Dhanjoris are involved in the deformation along the Singhbhum shear zone of the Mesoproterozoic North Singhbhum Mobile Belt (Joy and Saha, 1998, 2000; Matin et al., 2012; Banerjee and Matin, 2013). The Dhanjori Group is overlain by the Paleoproterozoic Chaibasa Formation without any apparent structural break.

The two sets of Sm-Nd isochron age determinations (Table 1) by Roy et al. (2002) and Misra and Johnson (2005), $2072 \pm 106$ Ma and $2787 \pm 270$ Ma respectively, cannot at present be reconciled. The Proterozoic deformation might have disturbed the isotope systematic, and the reliability of these dates may be questioned. Sunilkumar et al. (1996) determined the U-Th-Pb chemical ages of detrital zircons from the basal quartz-pebble conglomerate. The ages ranging from 3.04 to 3.09 Ga were regarded by them to represent the age of the provenance rock. Younger ages ranging from 2.10 to 2.74 Ga were ascribed to natural lead loss or lead loss during sample preparation. This was a preliminary study and more systematic work on the isotopes of detrital zircon grains is needed. The upper intercept ages determined from the discordant zircon grains from the acid tuff in the Phuljhari Formation are 3330+58 Ma and 3358+110 Ma (Acharyya et al., 2010b). Since the Mayurbhanj Granite with probable age of $3.1 \mathrm{Ga}$ intrudes (see Table 1) the Phuljhari Formation the Dhanjori Group ought to be $>3.1$ Ga old. Further work is necessary to arrive at a firm conclusion about the age of the Dhanjori Group.

\section{Simlipal Group}

The Simlipal basin in the eastern side of the Singhbhum Craton covers $\sim 9000 \mathrm{~km}^{2}$ area, has a circular outcrop pattern, and is surrounded by the SBG or unclassified granite (Fig. 1). The volcanosedimentary sequence of the basin overlies the Singhbhum and Kaptipada Granites and IOG of the Badampahar belt. It starts with basal quartz pebble conglomerate, orthoquartzite and feldspathic quartzite; the basal units are overlain by the volcanic pile (spilitic lavas and tuffs), with three intercalated bands of cross bedded quartzites (Iyengar and Banerjee, 1964). At the core of the complex in the uppermost part is a very thick ( $\sim 800 \mathrm{~m})$ differentiated sill, known as Amjhor or Amjori sill. The basal part of the sill consists of dunite followed up by peridotite, picrite, gabbro and quartz diorite. 
The origin and age of the basin remain unresolved. Along the flanks a suite of gabbro-anorthosite and the Mayurbhanj Granite intrude into the volcanics (Saha, 1994), testifying to its pre-MBG status. The Simlipal Volcanics is correlated with the Dhanjori Group mainly because of similar lithological associations in the two basins and their close proximity, but definite evidence about the correlation is lacking. Naqvi and Rogers (1987) floated the idea that the Simlipal basin may be an astrobleme or impact crater, but so far no evidence of any meteorite impact has been found.

\section{Mahagiri Quartzite, Keonjhar Quartzite, Mankaharchua Quartzite, Devgarh Quartzite, Malayagiri Supracrustals}

Extensive siliciclastic rocks are exposed along the western boundary of the Singhbhum Granite pluton separating the latter from the western IOG belt (Ghosh et al., 2015) (Fig. 1). The 1.5-kmthick siliciclastic succession, exposed between Joda and Keonjhargarh, has been named as Keonjhar Quartzite (Ghosh et al., 2016b). They are lateral equivalents of similar rocks extending from west of Keonjhar along the south-western and southern margin of the SBG up to Sukinda; the outcrop near Sukinda is named as the Mahagiri Formation or Mahagiri Quartzite (Mukhopadhyay et al., 2012, 2014) (Fig. 1). Similar siliciclastic rocks along the southern boundary of the Pallahara Gneiss have been named as Tikra Formation by Mahalik (1994). Siliciclastic rocks are also exposed north of Pallahara near Mankaharchua lying unconformably over the Malangtoli Volcanics (Fig. 1). All these siliciclastic rocks were previously regarded either as the basal unit of the IOG sequence, or alternatively as equivalents of the Kolhan Group or of the Dhanjori Group. Recent studies (Mukhopadhyay et al., 2007; Bandyopadhyay et al., 2010; Mazumder et al., 2012b) have conclusively proved that these are not a part of the IOG and may be broadly time-equivalents of the Upper Dhanjori Formation. The sandstone-conglomerate at the base of the sequence contains pebbles of BIF and a clear angular unconformity exists between the siliciclastic rocks and the underlying IOG rocks. U-Pb ages determined from detrital zircons from samples of sandstone coming from a large area extending from Keonjhar to Mahagiri and Mankaharchua cluster between 3950 Ма and 2909 Ма (Mukhopadhyay et al., 2014; Sreenivas et al., 2019). Paleo- and Mesoarchean ages (3510-3176 Ma) are dominant among the detrital zircon population. Some Eoarchean grains have ages of 3950-3601 Ma. The age of the granitic basement on which the sandstone lies is 3.29 Ga, and the sandstone is intruded by 2.8 Ga (Misra et al., 2000) old granitoids at the Mahagiri Range (Mukhopadhyay et al., 2014). Hence the age of deposition may be taken to be around 3.0 Ga.

The sandstones are texturally and mineralogically mature, preserving wave features. Ghosh et al. (2016b) inferred a continental interior setting for the siliciclastics. Several geochemical proxies indicate their highly matured and recycled nature and they have a mixed source of predominantly granodioritic and primitive mafic rocks belonging to a differentiated felsic upper continental crust (UCC). Evidence also points to the presence of both unweathered and deeply weathered source rocks. Their rare earth element patterns are similar to those of the post-Archean shales. The detrital uraninite grains in Mahagiri and Keonjhar Quartzites suggest existence of highly felsic and K-rich (richer than TTG) granodiorite-granite-monzogranite suites of rocks older than $2.9 \mathrm{Ga}$ in the Singhbhum craton. Dey et al.
(2017) have reported superchondritic $\varepsilon_{\mathrm{Hf}(\mathrm{t})}$ values $(+1$ to +8.75$)$ from detrital zircons in the Mahagiri Quartzite, suggesting predominantly juvenile mantle source.

The conglomerate-pebbly sandstone-dominated sequence in the lower part represents a subaerial alluvial plain to coastal braided sequence, and the mature quartz-arenite in the upper part is shallowmarine. The uraniferous paleoplacers occur mainly in coastal braided plain and proximal fan lobes. The siliciclastic sediments are underlain by pyrophyllite-bearing paleosol (Bandopadhyay et al., 2010) formed on the surface of the 3.29 Ga old granite (Tait et al., 2011). This is the oldest documented Archean paleosol in the Indian shield (Mukhopadhyay et al., 2014). The soft-sediment deformation in the paleosol near the contact with the overlying sandstone, indicates that the paleosol was wet at the onset of deposition of the overlying siliciclastic sediments. The soil type suggests alternation of very wet and very dry climates (Bandopadhyay et al., 2010). Geochemical evidence indicates that oxidative weathering occurred in the original upper soil profile, and the paleosol was formed before the deposition of the sediments. On the other hand, the presence of detrital uraninite and pyrite at the base of the siliciclastic sequence points to low surface oxygen condition during the time of deposition. Hence Mukhopadhyay et al. (2014) have invoked that a short-lived atmospheric oxygenation event occurred about 600 Ma prior to the Great Oxidation Event at $\sim 2.5 \mathrm{Ga}$. This probably took place because of the presence of organisms capable of oxygenic photosynthesis.

The stratigraphic status of the Malayagiri supracrustal belt (Sarkar et al., 1990) and NW of it of the Devgarh supracrustal belt south of the Bonai Granite (Mahalik, 1994) is uncertain. Both the belts contain BIF, siliciclastic rocks and volcanic/volcaniclastic rocks. The Malayagiri belt contains in addition to BIF, kyanite quartzite, quartzkyanite schist, garnet-staurolite-kyanite bearing schist and garnetbearing and garnet-free amphibolites (mafic rocks). The BIF-bearing Malayagiri sequence unconformably overlies the $\sim 2.8$ Ga old Pallahara Gneiss (Saha, 1994) and the zircon grains from the dacite in the supracrustal sequence have a concordant age of 2806+6 Ma (Nelson et al., 2014). Furthermore, the age of the youngest detrital zircon population from quartz-kyanite-muscovite schist is $2788+25 \mathrm{Ma}$ (Chattopadhyay et al., 2015). Chattopadhyay et al. (2015) concluded that the deposition of the Malayagiri supracrustals was between 2.79 and $2.42 \mathrm{Ga}$ and the rocks were affected by three major metamorphic events at $2.42 \mathrm{Ga}, 0.98-0.94 \mathrm{Ga}$, and 0.57-0.54 Ga.

\section{Kolhan Group}

The main Kolhan basin, covering an area of $\sim 600 \mathrm{~km}^{2}$, extends from Chaibasa to Noamundi, and straddles the boundary between the IOG of the western belt and the Singhbhum Granite (Dunn, 1940) (Fig. 1). The Kolhan sequence unconformably overlies the Singhbhum Granite and the Iron Ore Group, and is the youngest stratigraphic unit in the Singhbhum craton. It consists of three formations: the basal Mungra Sandstone followed by the Jhinkpani Limestone and the Jetia Shale. Jetia Shale often laterally grades to calcareous shale and encloses lenticular bodies of limestone. Locally there are thin intervals of manganese oxide interbedded with shale. Bandopadhyay and Sengupta (2004) suggested that the shale-dominated succession of the Kolhan sequence was deposited in continental rift setting. The lower red and purple sandstones with beds/lenses of conglomerates were deposited by shallow, ephemeral braided streams. The dominantly parallel-bedded sandstones with sheet-like geometry of 
the sandstone beds and rare channel-form structures imply that much of the sediments is a product of sheet floods, while the overlying thick and extensive shale was deposited in lacustrine environment. Petrography and geochemistry of the shales and CIA (Chemical Index of Alteration) values of the Kolhan siliciclastics suggest deposition in plate interior, either at stable continental margin or in intracratonic basin. An intensely weathered low-relief provenance dominantly composed of granitoid rocks and a warm and humid paleoclimate are also indicated. From the point of view of age, lithology, petrography, depositional environment and type of mineralization, the Kolhans may be compared with the manganese-bearing Wyllies Poort Formation of the Soutpansberg Group, Kaapvaal Craton, South Africa. The possibility has been suggested that the two cratonic blocks may have been juxtaposed in the Archean time.

Mukhopadhyay et al. (2006) have described the Kolhan succession as a siliciclastic shelf to deep-water carbonate platform succession. They suggested that the Kolhan succession represents a syn-rift to post-rift succession, which is equivalent to the terminal Mesoproterozoic carbonate platform successions developed in other parts of peninsular India. It represents an event of major transgression and relative sea level rise.

Ghosh et al. (2015) reported pervasive deformation features from the Kolhan basin and pointed out that the north-western boundary of the basin is marked by a major thrust fault, named as the Chaibasa thrust, with top-to south displacement along which older Archean succession was thrusted over the younger Kolhan rocks.

There are no reliable radiometric dates from the Kolhan Group. Mukhopadhyay et al. (2006), from lithostratigraphic and sedimentological considerations suggested a terminal Mesoproterozoic age.

\section{Darjing Group}

The region north of the Bonai Granite extending up to the Gangpur Group is occupied by a sequence of low-grade metamorphic rocks (Fig. 1) for which Mahalik (1987) proposed the name Darjing Group. The maximum age of the Darjing Group is constrained by the 3129+10 Ma age of the youngest detrital zircon grains (Chakraborty et al., 2019). It is intruded by the Tamperkola Granite having an age of 2809+12 Ma obtained from U-Pb dating of zircons (Bandyopadhyay et al., 2001). So the age of the Darjing Group is between 3.1 and 2.8 $\mathrm{Ga}$. The basal beds of the sequence rests unconformably on top of the Iron Ore Group and the Bonai Granite. It consists of three formations: Birtola Formation at the base followed upward successively by the Kumakela and Jalda Formations. Sm-Nd model ages $\left(\mathrm{T}_{\mathrm{DM}}\right)$ of the basal sandstones range from $~ 3.6$ to $4.0 \mathrm{Ga}$, clustering around $>3.3$ Ga-old crystallization ages of the tonalites and amphibolites. The higher model ages, as old as $\sim 4.0 \mathrm{Ga}$, suggest the presence of an Eoarchean crustal component in the craton (Saha et al., 2004). From trace elements and isotope geochemistry, and petrography of the sandstones Saha et al. (2004) suggested the source rocks to be the 3.3 Ga-old amphibolites of the OMG and tonalites of the OMTG. Strong $\mathrm{Nb}$-Ta depletion relative to the primitive mantle suggests the sandstones to be derived from subduction-related magmatic arc sources and the basement rocks on which this arc was formed must have included components older than $3.3 \mathrm{Ga}$ continental crust.

There are scanty data on detailed structural geometry of the Darjing Group. Alternative stratigraphic groupings of the rocks of this region have been proposed by Sen (2001) and Naik (2001). The differences in interpretations are to be sorted out by detailed mapping and facies analysis of the sediments.

Chakraborty et al. (2019) used the term Upper Bonai Group for the supracrustal sequence that includes the Darjing Group and extends up to the SBG pluton. Two major metamorphic episodes are recorded in the rocks - an earlier $M_{1}$ episode produced garnet ${ }_{1}$ and staurolite, $\mathrm{M}_{2}$ produced garnet ${ }_{2}$ which grew at the expense of staurolite. The estimated P-T conditions are: $\mathrm{M}_{1}-520^{\circ}-580^{\circ} \mathrm{C}, 4.8 \mathrm{~kb} ; \mathrm{M}_{2}-650^{\circ} \mathrm{C}$, $7.4 \mathrm{~kb}$. The Upper Bonai Group is intruded by garnet-bearing granites which are deformed.

\section{Supracrustal rocks with debatable stratigraphic status}

The low grade phyllites, tuffs and quartzites at the NW corner and along the northern part of the western edge of the SBG pluton have a debatable stratigraphic status. Dunn (1929) and many of the later workers regarded these to be a continuation of the upper part of the IOG sequence exposed in the core of the "horse-shoe synclinorium” (Sarkar and Saha, 1962; Saha, 1994). On the other hand, Mukhopadhyay (1976) opined that these are the western continuation of Dhanjori Group. They underlie the Chaibasa Formation of the North Singhbhum Mobile Belt. The boundary of this western extension of the Dhanjori Group with the IOG of the western belt remained undefined. Mazumdar (1996) placed these rocks in a different group named as the Bonai Group unconformably overlying the SBG and separated from the IOG of the western belt by a NW-trending fault passing south of Jojuhatu. Bhattacharya and Mahapatra (2008) grouped the rocks unconformably lying over the northern and northwestern boundary of the Singhbhum Granite in two units, the Bisrampur Formation and the Nayadih Formation, which were thrusted over by the Iron Ore Group and the Dhanjori Group in the north (Fig. 7b). Ghosh et al. (2015) inferred the presence of two thrust sheets within the phyllites and quartzites of this area (Fig. 7a). The lower thrust is comprised of Lupunggutu Formation of chlorite schist intermingled with fine-grained sandstone-mudstone, greywacke, and shale/phyllite, and the unconformably overlying Achu Formation of siliciclastic rocks (conglomerate, arkosic sandstone, shale/phyllite). The upper thrust sheet is composed of the same two formations along with the Ongarbira Volcanics. The upper boundary of this stack of thrust sheets is the Singhbhum Shear Zone (SSZ) of the NSMB. According to this interpretation this group of siliciclastic rocks is older than the Dhanjoris. This is an interesting hypothesis, but it needs to be confirmed by more detailed structural mapping over a larger region and geochronological work.

\section{Ultramafic-Mafic-Anorthosite Suites}

Ultramafic-mafic-anorthosite suites mostly occur along the eastern side of the Singhbhum Craton as a number of linear discontinuous bodies extending from south of Haludpukur to Nuasahi and Sukinda (Fig. 1). Ultramafic rocks are also present at Jojohatu, south of the Ongarbira Volcanics and also at east of the Bonai Granite (Fig. 1). The ultramafic rocks of Sukinda-Nuasahi are intrusive into the Singhbhum Granite and are intruded by the Mayurbhanj granite and granophyre (Saha, 1994). Auge et al. (2003) reported 3123 $\pm 7,3122 \pm 5$ and 3119+6 Ma zircon ages from the gabbroic suite at Nuasahi, and $3205 \pm 280$ Ma Sm-Nd isochron age of the gabbroic suite. This also puts an upper limit on the age of the Mayurbhanj Granite (MBG). At 

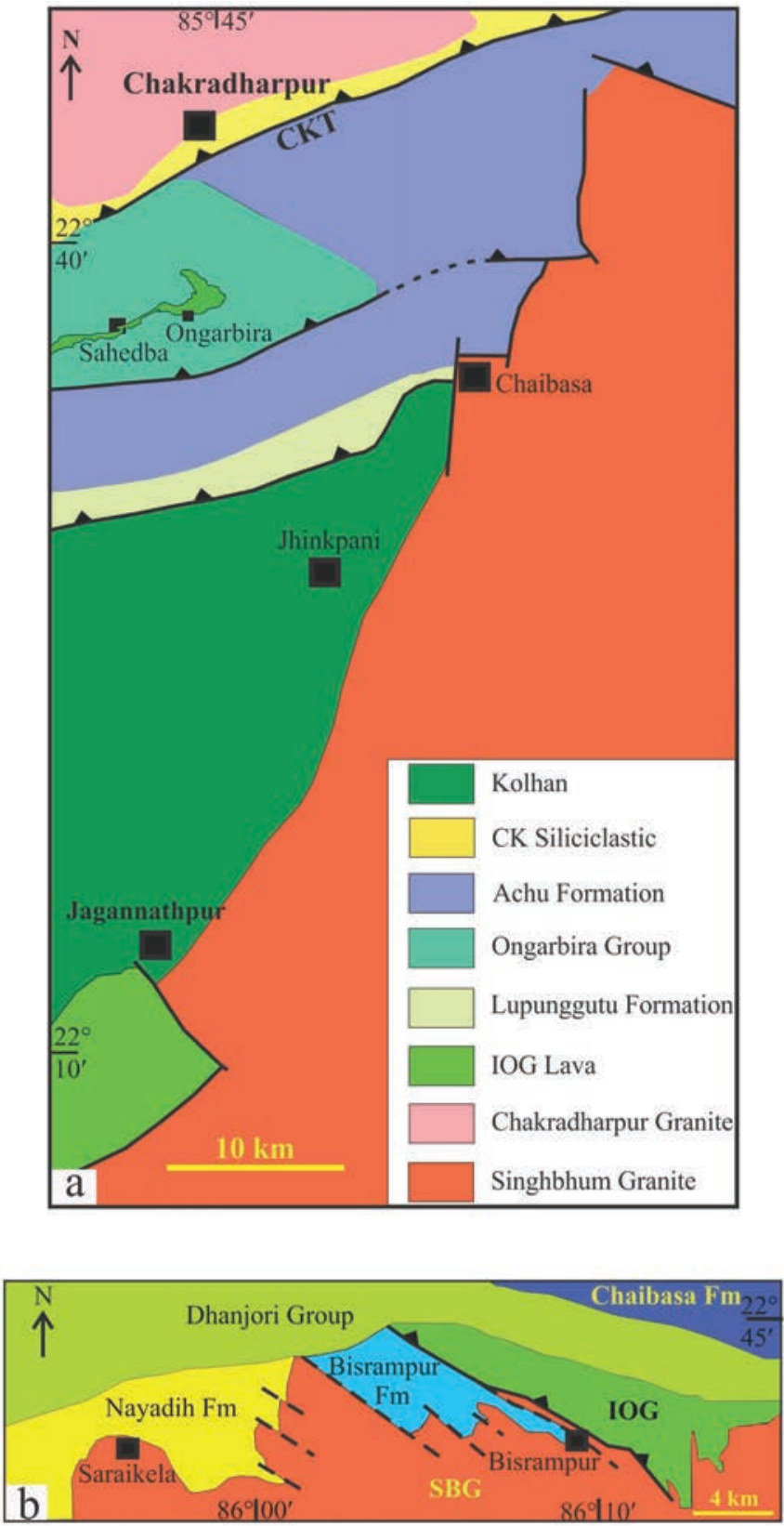

Figure 7. a. Geological map of the northwestern edge of the Singhbhum Granite pluton, showing the stacked thrust sheets over the Kolhan Group (after Ghosh et al., 2015). b. Interpreted stratigraphic set up at the northwestern corner of the Singhbhum Granite pluton (after Bhattacharya and Mahapatra, 2008).

Sukinda and Nuasahi the intrusive body is a layered ultramafic body, with ultramafics in the lower part and gabbro with anorthosite in the upper part. There is no direct age determination of the emplacement of the ultramafics, but probably this was between 3.3 and $3.1 \mathrm{Ga}$. The ultramafic rocks are picrite, lherzolite, orthopyroxenite, harzburgite, dunite and chromitite and characteristically show adcumulate texture. The parent magma is boninitic or siliceous high-Mg basalt (SHMB) (Mondal, 2009; Khatun et al., 2014; Mondal et al., 2019). The spidergrams of trace elements in gabbro samples show negative $\mathrm{Nb}$, Th, Zr, and Hf anomalies indicating derivation from a depleted mantle (Mondal and Zhou, 2010). $\varepsilon_{\mathrm{Nd}(\mathrm{t})}$ value of $+2.63 \pm 0.88$ for the high$\mathrm{Mg}$ gabbroic suite is consistent with an origin from a long-term depleted source region. The geochemistry and REE patterns suggest that the boninitic parental magma was generated by second-stage melting of a metasomatized depleted mantle source in a suprasubduction setting. The high Os concentrations (and IPGE-rich character in general) of the studied Archean chromitites are supportive of the idea of a high degree of melting of a previously depleted upper mantle source domain for generating the parental melts of chromitebearing ultramafic suites (Mondal et al., 2004, 2006).This points to the presence of early Archean SCLM (sub-continental lithospheric mantle) domain beneath the SC. SCLM domain represents the stable residue after extensive melt extraction in the Archean. Os model age calculation from the chromites indicate that depletion from the primitive mantle to form the SCLM started as early as $\sim 3.7 \mathrm{Ga}$, nearly 500 to 600 Ma earlier than the crystallization of chromite (Mondal et al., 2007). This tallies with the conclusion derived from the istopic data from granitoid rocks discussed earlier. Alternatively, the parent melts may have come from depleted zones surviving within the convective mantle. Mondal et al. (2007) hypothesized that the parental magma of the ultramafic suite was produced in a supra-subduction zone setting and intruded into the volcano-sedimentary greenstone belts at shallower crustal levels. They envisioned a process of early subduction of sections of melt-depleted subchondritic oceanic lithospheric mantle with large degree melt extraction events and concomitant major crust building processes during middle to late Archean in the Singhbhum Craton. A supra-subduction zone setting has recently been suggested to explain the existence of boninite-like metabasalts in the $3.7 \mathrm{Ga}$ old Isua Greenstone Belt in Western Greenland (Polat et al., 2002; Polat and Frei, 2005). Mondal (2009) has proposed that similarity of the sub-continental lithospheric mantle characteristics of the Singhbhum Craton and the Zimbabwean craton suggest that South Africa and India were parts of the same supercontinent in early Archean (Myers, 1995).

\section{Newer Dolerite Dyke Swarm}

Spectacular dyke swarms called the Newer Dolerite traverse the Singhbhum Granite pluton and occasionally occur within the Bonai Granite, Kaptipada Granite and Mayurbhanj Granite. Such dyke swarms are interpreted to represent the plumbing systems of LIPs which are deeply eroded to expose the feeder dykes (Ernst, 2014). Hence they are useful for identifying Large Igneous Provinces (LIPs) and for paleogeographic reconstruction (Srivastava et al., 2016). The dominant trend of the near vertical dykes within the Singhbhum Granite is NNE-SSW to NE-SW; subsidiary trends are NW-SE and $\mathrm{E}-\mathrm{W}$. The dimension of the dykes varies from a few tens of $\mathrm{cm}$ to one $\mathrm{km}$ in width and from a few hundred metres up to $20 \mathrm{~km}$ in length. Mandal et al. (2006) opined that the dykes form a conjugate set of shear fractures formed in a regime of overall N-S compression. However, this interpretation is problematic because the dykes have widely different ages and may have formed under different stress regimes.

Saha (1994) recognized three petrogenetic groups within the dyke swarm; (a) the ultramafic and lamprophyric cumulates, (b) products of direct magmatic crystallization, and (c) products of partial fusion of granitic wall-rocks during ascent of mafic magma, including leucogranophyre without appreciable admixture of mafic magma and xenolithic granophyres with appreciable admixture of mafic magma.

Roy et al. (2004) reported that the $\varepsilon_{\mathrm{Nd}(t)}$ values from two ultramafic dykes vary from +1.23 to -3.27 ; the $\delta^{18} \mathrm{O}$ values vary from $+3.16 \%$ 
to $+5.29 \%$ o (average $+3.97 \%$ o $\pm 0.75 \%$ ) which is lower than the average mantle value. Isotopes, trace elements and REE data together indicate that by $2.6 \mathrm{Ga}$ both depleted and enriched mantle reservoirs were established below the Singhbhum craton. The main depletion events are associated with the major crust building activities. They postulate that the nearly primitive mantle below the Singhbhum Craton was metasomatized by the fluid (with or without silicate melt) coming out from the subducting early crust resulting in the formation of enriched mantle. Magmatic blobs of this metasomatized mantle were subsequently emplaced as ultramafic dykes in deeper levels of the granitic crust which possibly originated due to the same thermal pulse.

Mir et al. (2010, 2013) have also suggested derivation of the dykes from a mantle source metasomatized by a subduction component (e.g., fluids derived by dehydration of the subducting slab or partially melting sediments).

Recently $\mathrm{Pb}-\mathrm{Pb}$ baddeleyite ages of $1766 \pm 1$ and $1765 \pm 1$ Ma were obtained for the WNW'ly trending swarm (Shankar et al., 2014). Dykes of this trend distinctly cut across dykes of other orientations and possibly represent one of the youngest swarms in the region. Coeval mafic magmatism has been found in North China Craton, Kimberley Basin in Australia, Rio de Plata Craton, Uruguay and Brazilian craton. This points to the assembly of the supercontinent Columbia. Kumar et al. (2017) recognized three distinct trends in the Newer Dolerite dyke swarm: NNE-SSW, NW-SE and WNW-ESE. Based on cross-cutting field relations the NNE'ly trending swarm appears to be the oldest. Six dykes from this swarm have yielded Pb$\mathrm{Pb}$ baddeleyite ages ranging between $2764 \mathrm{Ma}$ and $2760 \mathrm{Ma}$, with a weighted mean age of $2762 \pm 2 \mathrm{Ma}$. This is inferred as the emplacement age of this swarm. Baddeleyite from the NE-SW to ENE-WSW trending Kaptipada swarm has been dated by Srivastava et al. (2016, 2019). They give a weighted mean of $2251 \pm 2 \mathrm{Ma}$ for the ${ }^{207} \mathrm{~Pb} /{ }^{206} \mathrm{~Pb}$ ages of the samples. They favour an upper intercept of $2256 \pm 6$ Ma as the best estimate of the age of the Kaptipada swarm.

The mean paleomagnetic pole position obtained from the dykes of the NNE-SSW trending swarm by Kumar et al. (2017) is $14^{\circ} \mathrm{N}$, $78^{\circ} \mathrm{E}$. This is comparable to one of the pole positions obtained earlier by Verma and Prasad (1974). The similarity of determined paleolatitudes and the broad contemporaneity of the 2762, 2800, 2752 Ma magmatic events in the Singhbhum Craton, the Pilbara Craton of Australia, and the Kaapvaal craton of South Africa led Kumar et al. (2017) to suggest that these three cratons were assembled together in the Neoarchean time to form the Vaalbara Supercraton.

Based on field relations and U-Pb dating, the Newer Dolerite dykes have been grouped by Srivastava et al. (2019) in seven distinct swarms. These range in age from $\sim 2.80 \mathrm{Ga}$ to $1.76 \mathrm{Ga}$, and include the following:

1. Keshargaria swarm - $2.8 \mathrm{Ga}$, NE-SW trending.

2. Ghatgaon swarm - 2.76-2.75 Ga, NNE-SSW to NE-SW trending, most extensive swarm.

3. Keonjhar swarm - Between 2.76 and 2.26 Ga (earlyPaleoproterozoic), NNE-WSW to E-W trending with radiating pattern.

4. Kaptipada swarm - 2.26 Ga, NE-SW to ENE-WSW trending with radiating pattern.

5. Bhagamunda swarm - Between 2.26 and 1.77 Ga (middlePaleoproterozoic), NNW-SSE to NW-SE trending with radiating pattern.

6. Pipilia swarm - 1.77 Ga, WNW-ESE trending.
7. Barigaon swarm - $<1.77 \mathrm{Ga}$, late Paleoproterozoic, N-S to NNE-SSW trending, radiating pattern.

Except for the Pipilia swarm which has similar age as the Dalma Volcanics of the NSMB, none of the other dyke swarm can be linked to a specific episode of mafic magmatic activity within the Singhbhum Craton. The Kaptipada swarm (2.26 Ga) and the Pipilia swarm (1.76 $\mathrm{Ga}$ ) are closely matched with two swarms of comparable age in the Dharwar Craton, and Srivastava et al. (2019) have tentatively identified two swarms of similar ages in the Bastar Craton. They have, therefore, concluded that by at least 2.26 Ga the Dharwar, Bastar and Singhbhum cratons were joined together, and two LIPS existed at the two above mentioned times covering all the three cratons. They further suggested that the trends of the 2.26 Ga dykes in the three cratons display a radiating pattern and they converge to define a possible plume centre at the northeastern end of the Dharwar-Bastar join. The 1.76 Ga swarms in the three cratons, on the other hand, display parallel trends. They had also correlated the NNE-SSW trending Ghatgaon swarm (2.76-2.75 Ga) of the Singhbhum Craton with the WNW-ESE trending Keshkal swarm (2.7 Ga) of the Bastar Craton, and the dyke trends converge to a possible plume centre situated SE of the Bastar Craton. However, in the absence of paleomagnetic data these reconstructions would remain speculative.

\section{Window on the Hadean and the Eoarchean Earth}

Paleoarchean ages dominate among the determined ages from the different granitoid units making up the SC. But some information about still older crust can be gleaned from detrital zircon grains in the supracrustal rocks and from xenocrystic zircon grains in the granitoid gneisses. The existence of Eoarchean continental crust was first indicated by the $\mathrm{Pb}-\mathrm{Pb}$ ages (using a small ion microprobe) of detrital zircon grains from OMG orthoquartzites, the ${ }^{207} \mathrm{~Pb} /{ }^{206} \mathrm{~Pb}$ ages of a few cores being 3628+72, 3583+50, and 3591+64 Ma (Goswami et al., 1995).

The oldest reported Hadean ages from the SC are the SHRIMP concordant ages ( 4.03 to $\sim 4.24 \mathrm{Ga}$ ) of xenocrysts of zircons in the OMTG ( 3.4 Ga old) from near Champua (Chaudhuri et al., 2018); these have thin rims with oscillatory zoning and the rims have discordant Eoarchean ( 3.8 to $\sim 3.9 \mathrm{Ga}$ ) ages (Table 1). The cores of other xenocrysts yield Eoarchean crystallization ages ( 3.7 to $\sim 3.6$ $\mathrm{Ga})$. These xenocryst ages are indicative of the existence of continental crust during the Eoarchean and Hadean times. The Hadean xenocrysts have unradiogenic ${ }^{176} \mathrm{Hf} /{ }^{177} \mathrm{Hf}$ initial compositions $(0.27995 \pm 0.0009$ to $0.28001 \pm 0.0007)$, and the $\varepsilon_{\mathrm{Hf}[\mathrm{t}]}$ values range from -2.5 to -5.2 , suggesting that they originated from Hadean enriched reservoir (Fig. 5). Time integrated $\varepsilon_{\mathrm{Hf}[\mathrm{t}]}$ compositional array of the Hadean xenocrysts indicates a mafic protolith with ${ }^{176} \mathrm{Lu} /{ }^{177} \mathrm{Hf}$ ratio of 0.022 (Fig. 5) that was reworked during $\sim 4.2-4.0 \mathrm{Ga}$. Calculations using the isotopic data suggest that the separation of such an enriched reservoir from chondritic mantle took place at $4.5 \pm 0.19 \mathrm{Ga}$, that is, soon after (after $\sim 40 \mathrm{Ma}$ ) the accretion of the Earth and was reworked during 4.2 Ga. This mafic source may represent an enriched residual mafic crust generated from a partially solidified magma ocean. More radiogenic yet subchondritic ${ }^{176} \mathrm{Hf} /{ }^{177} \mathrm{Hf}$ values for some other zircon grains are as follows: $\sim 3.6$ to $\sim 3.7$ Ga old zircon grains with $\varepsilon_{\mathrm{Hf}(\mathrm{t})}=$ 1.5 to $-6.6, \sim 3.4$ Ga old zircons with $\varepsilon_{\mathrm{Hf}(\mathrm{t})}=-0.4$ to -3.7 from OMTG, $\sim 3.4$ and $\sim 3.3$ Ga zircons from the Singhbhum Granite with $\varepsilon_{\mathrm{Hf}(\mathrm{t})}=-$ 
0.3 to -4.7 . These have been interpreted by Chaudhuri et al. (2018) to indicate that the enriched Hadean reservoir subsequently underwent mixing with depleted-mantle-derived juvenile magma during Eoarchean to Paleoarchean.

Sreenivas et al. (2019), based on SHRIMP and LA-MC-ICPMS measurements, reported Eoarchean detrital zircons (3950-3601 Ma crystallization age) from Mesoarchean ( 3.0 Ga) Mahagiri Quartzite (Fig. 1) in the southeastern part of the SC (Table 1). Their $\mathrm{T}_{\mathrm{DM}}$ ranges from 4.51 to $4.15 \mathrm{Ga}$, and they show unradiogenic $\varepsilon_{\mathrm{Hf}(\mathrm{t})}$ values ranging from $-3.37 \pm 0.5$ to $-9.75 \pm 0.4$, suggesting an enriched source. The authors interpret that the Eoarchean zircon grains represent crust generated by recycling of Hadean felsic crust formed at $\sim 4$.3 to 4.2 Ga and 3.95 Ga (Fig. 5).

Miller et al. (2018) carried out U-Pb age determinations with the help of LA-MC-ICPMS of detrital zircon grains in modern river sediments of the Baitarini River basin that is wholly contained within the SC. The data for grains which are less than 5\% discordant are principally grouped in three clusters: 3.62-3.55 (5\%), 3.50-3.22 (87\%) and 3.10-3.06 Ga (6\%). One grain (1.3\% discordant) shows a Hadean age of 4015 \pm 9 Ma (Table 1). Single stage Lu-Hf model ages of these grains range from 4.29 to $3.10 \mathrm{Ga}$. Since Lu-Hf model age is an estimate of the time when the protolith of the rock left the uniform chondritic reservoir, these model ages suggest the existence of Hadean, Eoarchean and younger crust. The $\mathrm{e}_{\mathrm{Hf}[\mathrm{t}]}$ values show a range, $67 \%$ values being positive scattered above and below the depleted mantle growth curve, and 33\% values are negative. This indicates contribution from both depleted mantle and enriched crustal sources. The Hadean grain $(4.015 \mathrm{Ga})$ had an $\mathrm{e}_{\mathrm{Hft}[\mathrm{t}}$ value of -5.3 suggesting an enriched, likely crustal, influence on the parent magma.

All the data sources have yielded similar results and have arrived at similar conclusions. Collectively the data show a contiguous spread of zircon ages from 4.2 to $3.6 \mathrm{Ga}$ (Fig. 4). Therefore, there is ample evidence of early mantle depletion and formation of enriched crust during the Hadean and Eoarchean time under the Singhbhum Craton. Olierook et al. (2019) have drawn attention to the interesting fact that 4.24 Ga and 4.03-4.01 Ga ages obtained in Singhbhum Craton are similar to two peaks in the global Hadean zircon records (Griffin et al., 2014; Marchi et al., 2014).

\section{Evolutionary History and Geodynamic Considerations}

There is an intense debate on the geodynamics of crust formation during the Hadean and Archean times (Hawkesworth et al., 2010, 2017; Giffin et al., 2014). Basically there are two contending hypotheses; (1) plume-driven, and (2) subduction-driven lithospheric evolution. Some hold the view that some form of subduction and plate tectonics was an important process contributing to crust formation and it started from Eoarchean and even Hadean times (Polat et al., 1998, 2002, 2016; Nutman et al., 2007; Reimink et al. 2014; Kaczmarek et al., 2016 ). Others (Puchtel et al., 1998; Polat et al., 2006; van Kranendonk, 2010; Moyen, 2011; Johnson et al., 2014, 2017; van Kranendonk et al., 2004, 2015) suggest that plume-related processes are in the main responsible for the Archean crust formation. For the Singhbhum Craton also a number of models have been proposed. These include, a plume origin (Sharma et al., 1994), repeated diapiric rise of felsic magma, punctuated by sedimentation in basins peripheral to the domical central part of the craton (Nelson et al.,
2014), crustal melting in response to plume driven magmatic underplating in an oceanic plateau setting (Dey et al., 2017), and island arc type accretionary setting (Saha et al., 2004; Mukhopadhyay et al., 2008c, 2012; Tait et al., 2011; Manikyamba et al., 2015; Singh et al., 2016).

Evidence about the existence of Hadean and Eoarchean continental crust that is $>500$ Ma older than the oldest preserved continental crust in the Singhbhum Craton comes from detrital zircon grains in the supracrustal rocks and river sands and zircon xenocrysts in granitoids. However, the felsic rocks of this ancient age are completely reworked and recycled attesting to a highly unstable tectonic regime. Halfnium isotopic data from zircons in Jack Hills supracrustal rocks (Yilgarn Craton) (Blichert-Toft and Albarede, 2008; Kemp et al., 2010), the Acasta Gneisses (Slave Craton) (Iizuka et al., 2009; Bauer et al., 2017), Greenland rocks (Fisher and Vervoort, 2018), particularly the Isua Supracrustal Belt (Greenland) (Bennet et al., 1993; Caro et al., 2006) and the Nuvvuagittuq Supracrustal Belt (Canada) (O’Neil et al., 2008), provide evidence of early mantle depletion and existence of enriched crust during Hadean to Eoarchean. In the Singhbhum Craton too evidence of early mantle depletion and existence of an enriched reservoir during Hadean and Eoarchean come from zircon grains older than $3500 \mathrm{Ma}$; these display exclusively subchondritic (negative) $\varepsilon_{\mathrm{Hf(t)}}$ values (Fig. 5), signifying the existence of non-chondritic enriched mantle reservoir as early as $\sim 4.2 \mathrm{Ga}$. It is hence inferred that the source reservoirs of the rocks with Hadean and Eoarchean zircon grains had separated from the chondritic material quite early in the Earth's history.

Chaudhuri et al. (2018) proposed that in the $\varepsilon_{\mathrm{Hf}[\mathrm{t}]}$ vs. Age diagram a straight line corresponding to ${ }^{176} \mathrm{Lu} /{ }^{177} \mathrm{Hf}=0.022$ fits with the plots of the Hadean zircon grains (Fig. 5). This corresponds to an enriched source area like a 'mafic protocrust' that separated from the chondritic reservoir at $\sim 4.5 \mathrm{Ga}$, soon after ( $\sim 40 \mathrm{Ma}$ ) the accretion of the Earth. They envisaged that the enriched residual mafic magma was generated in an essentially non-plate tectonic way from a partially solidified magma ocean analogous to KREEP (K, REE, P) rich basalt below the lunar anorthositic crust (Kemp et al., 2010). It has also been suggested that the primordial crust that covered the Hadean Earth when the magma ocean solidified was made up of komatiites and related rocks (Santosh et al., 2017, and references therein). Hadean and Eoarchean zircon crystallized from minor silicic melts produced by differentiation or remelting of this pre- $\sim 4.2$ Ga juvenile mafic protocrust. The presence of Paleoarchean granites with subchondritic $\varepsilon_{\mathrm{Hf(t)}}$ values (Fig. 5) signifies that the enriched reservoir was sustained till the Paleoarchean.

For the Eoarchean zircons from the SC the Hf isotopic ratios are more radiogenic but still subchondritic. While Chaudhuri et al. (2018) are of the view that the second stage of melt generation during Eoarchean was from the mafic protocrust (enriched source) modified by its interaction with juvenile (more radiogenic) mantle melt, Sreenivas et al. (2019) proposed that the plots of Hadean and Eoarchean zircons fit into two broad trajectories with ${ }^{176} \mathrm{Lu} /{ }^{177} \mathrm{Hf}=$ 0.008 , and these correspond to TTG-like sources that formed at $\sim 4.3$ - 4.2 Ga and 3.95 Ga respectively (Fig. 5); that is, according to them the Eoarchean zircons represent crust generated by recycling of Hadean felsic crust. There is no unequivocal evidence to choose between the two hypotheses. Sreenivas et al. (2019) remarked that the continuous involvement of the enriched reservoirs between 4.2 and $3.6 \mathrm{Ga}$ is not consistent with magma generation through plate tectonic processes. 
High heat production in the Archean and Hadean times probably led to more rapid mantle convection which was responsible for quick recycling of the Hadean protocrust preventing its preservation. Hence the mafic Hadean protocust in the Singhbhum craton has not survived and has been recycled and assimilated into the younger voluminous TTG magma. The amphibolite enclaves within the OMTG and the SBG may represent the remnants of the oldest mafic protocrust or these enclaves could represent a modified mafic component developed from interactions between the ancient enriched reservoir and mantlederived juvenile mafic magma and were preserved as melting residuum of the mafic protolith from which granitoid magma was generated. A definite conclusion will have to wait till we get more geochemical and isotopic data from the enclaves. Because of the quick assimilation or recycling into the mantle of the Hadean protocrust it has been suggested that the early depleted mantle was likely to be transient (Bennet et al., 1993; Zeh et al., 2008).

From $~ 3.6-3.5 \mathrm{Ga}$ a shift in the isotopic composition of $\mathrm{Hf}$ is noticed, marked by upward excursion of $\varepsilon_{\mathrm{Hf}(\mathrm{t})}$ plots towards suprachondritic values (Fig. 5). This signifies that the early enriched reservoir underwent modifications through serial mixing with depleted mantle-derived juvenile magma. A large number of samples of Paleoarchean zircons have suprachondritic ${ }^{176} \mathrm{Hf} /{ }^{177} \mathrm{Hf}$ values which attests to the importance of magma generation from a depleted mantle reservoir at this time (Dey et al., 2017). Thus a major depletion of the mantle and concomitant extensive continental crust formation started in the SC from 3.5 Ga. Therefore, a separate depleted reservoir which was probably complementary to the ancient enriched reservoir existed under the Singhbhum craton in the Paleoarchean. Chaudhuri et al. (2018) suggested that the $\sim 3.4$ Ga komatiites of the eastern IOG belt with $\varepsilon_{\mathrm{Nd}(\mathrm{t})}=+2$ to +4 are the most plausible direct representives of the depleted lower mantle below the SC.

The evidence for Paleoarchean mantle depletion also comes from the study of IOG mafic-ultramafic rocks and the chromitites of Sukinda and Nuasahi (Mondal et al., 2007). Mondal et al. (2007) concluded on the basis of Sm-Nd isotopic composition that the high-Mg mafic rocks of the IOG in Sukinda and Nausahi and the OMG amphibolites are nearly contemporaneous. The $\varepsilon_{\mathrm{Nd}(\mathrm{t})}$ ratios are +ve and suggest a long-term depleted source region. They proposed suprasubduction setting for the generation of the parental magma that produced the ultramafic suite. The ${ }^{187} \mathrm{Os} /{ }^{188}$ Os ratios of the Sukinda and Nausahi chromitites are unradiogenic and the isotopic data led them to conclude that a subcontinental lithospheric mantle (SCLM) started to form beneath the Singhbhum Craton in early Archean ( 3.7 Ga) by depletion of a primitive mantle, more than 500 Ma earlier than the crystallization of chromitite. An alternative possibility is that the depleted mantle region could have remained within the convecting mantle for a few hundred million years before being added to the SCLM beneath the Singhbhum Craton.

During the Paleoarchean period the central part of the Singhbhum Craton was built up through successive pulses of granitic magmatism. Felsic magmatism at 3.52 Ga, 3.47-3.43 Ga, 3.40-3.35 Ga produced the TTG-type suite of the OMTG. The ages indicate that some parts of OMTG are older than the OMG and some are younger intrusions (cf. Roy and Bhattacharya, 2012). Younger pulses at 3.32-3.35 Ga, and 3.31-3.28 Ga produced the voluminous granitic magma that engulfed the OMTG and produced the composite pluton of the Singhbhum Granite. This was also a period of major metamorphism in the terrain (3.34-3.26 Ga). Younger tectonothermal events also affected the craton.
On the basis of the geochemical parameters and the $+v e \varepsilon_{\mathrm{Hf(t)}}$ values of the SBG samples studied by them, Dey et al. (2017) concluded that the 3471 Ma-old tonalite was produced by shallow melting of a juvenile mafic source, derived from a depleted mantle, and the 3347 Ma-old granite was produced by high-temperature melting of a heterogeneous juvenile source of tonalites and mafic rocks at low crustal depths and the younger 3304 Ma-old granite was produced by high-pressure melting of tonalite-dominated source with short crustal residence. There was no direct involvement of the mantle in the origin of any of these granitoid rocks.

Regarding tectonic setting Dey et al. (2017) proposed crustal reworking driven by episodic plume-related mafic-ultramafic magma underplating and intraplating in an oceanic plateau setting as a model for the origin of the Singhbhum granitoids. Melting of mafic crust at different depths within the thick oceanic crust led to variation in composition of the different pulses of felsic magmatism. Bédard (2006) has discussed how successive plume activities may build up a thick volcanic crust which in its lower part is metamorphosed into amphibolite. Successive underplating of magma melts the amphibolite at the base of the crust to produce successive generations of tonalite melt. The older generation of tonalites are extensively remobilized and also contribute to the younger tonalites.

In contrast to the plume hypothesis, the geochemical signatures within a 3290 Ma-old weakly peraluminous TTG body within the SBG pluton led Tait et al. (2011) to infer a volcanic arc paleotectonic setting at a crustal margin. Furthermore, the geochemistry of the Mgrich OMG volcanics with boninitic affinity is taken to point to their genesis in intra-oceanic subduction setting (Manikyamba et al., 2015). From the geochemistry of sedimentary rocks sourced from OMGOMTG, Saha et al. (2004) inferred that the OMG-OMTG formed a subduction-related arc complex at $\sim 3.3 \mathrm{Ga}$. The OMG and the IOG in the three belts are broadly contemporaneous or formed within a time interval of about $100 \mathrm{Ma}$ (between 3.5-3.4 Ga). The IOG belts are thought to have formed in a supra-subduction setting (Basu et al., 2008; Mukhopadhyay et. al., 2012; Singh et al., 2016, 2017), with the deposition of the supracrustals variously thought to be in rifted arc, back-arc or fore-arc basins.

Saha et al. (2004) concluded on the basis of REE abundances and Sm-Nd isotopic characteristics that the sandstones from the Birtola Formation of the Darjing Group were derived from the OMG amphibolites and OMTG tonalites. They pointed out that the strong $\mathrm{Nb}$-Ta depletion relative to the primitive mantle suggests the sandstones to be derived from subduction-related magmatic arc sources. The low $\mathrm{Nb} / \mathrm{Ta}$ and high $\mathrm{Zr} / \mathrm{Sm}$ ratios of these sandstones are identical to those for the Archean tonalite-trondhjemites that require, based on recent trace-element partitioning results, their protoliths to have formed by subduction melting of low magnesium amphibolites or metamorphosed hydrous basalts. Saha et al. (2004) inferred that subduction-accretion processes operated during the midArchean in the Singhbhum Craton. For the mid-Archean Dhanjori Group, De et al. (2015) suggested a sedimentary provenance in a felsic Andean-type magmatic arc.

Malangtoli Volcanics which are regarded as the basal unit of the eastern IOG sequence are characterized as an arc basalt-boninitehigh magnesian andesite-Nb enriched basalt (Singh et al., 2016, 2017). Their geochemical attributes reflect different stages of subduction and genesis of the volcanics in fore-arc to rifted back-arc setting in a region proximal to active continental margin.

From geochemical considerations Mukhopadhyay et al. (2008c) 
suggested that the southern IOG belt is akin to an ophiolite formed in a supra-subduction setting. They suggested a non-plume source for the volcanics and their formation in an extending oceanic-arc-forearc geodynamic setting. Geochemistry of the southern BIFs suggest their deposition in close proximity to spreading centres that might have developed over a rifted arc.

The geochemical characters of the komatiites in the eastern IOG were interpreted by Chaudhuri et al. (2015) to indicate mantle plume activity in an oceanic/arc setting. Later Chaudhuri et al. (2017) on the basis of an enlarged data set suggested geochemical affinity of the Singhbhum komatiites with other non-arc plume related oceanic basalts pointing to their emplacement in oceanic tectonic settings.

In summary, the Singhbhum Craton is built up multiple pulses of discrete mantle plume events. Episodic plume-related mafic-ultramafic magma underplating and intraplating, and repeated crustal reworking generated the felsic magmas (Olierook, 2019). These mantle plumes probably operated in a stagnant-lid tectonic regime at least in the Hadean and Eoarchean times, but appear to be punctuated by discrete subduction zone events as witnessed by the deposition of several volcano-sedimentary sequences in supra-subduction setting. The Singhbhum Craton possibly records a transition from plume-driven stagnant lid tectonics to active subduction-related tectonics at 3.5 Ga (Sreenivas et al., 2019). While the OMG supracrustals were incorporated within the intrusive granitic bodies and were co-deformed and co-metamorphosed at $~ 3.3-3.2 \mathrm{Ga}$, the peripheral IOG basins were accreted to the OMTG-SBG composite pluton without suffering much metamorphism. The timing of this accretion is not precisely defined (Prabhakar and Bhattacharya, 2013). The major metamorphism at 3.34-3.26 Ga is at present the best estimate.

It is generally believed that the Earth was once covered by a magma ocean (Elkins-Tanton, 2012). When the magma ocean solidified the Hadean Earth was covered by a mafic protocrust. This formed the lid and stagnant-lid (or single-lid) tectonics was likely to be the common mechanism at this stage (Stern, 2018). Bédard (2018) has discussed that the stagnant-lid behaviour was likely to be periodically disturbed because of perturbations in the Earth's heat generation/loss balance, eventually triggering mantle overturns. Archaean basalts were derived from fertile mantle in overturn upwelling zones (OUZOs), which were analogous to, but larger than and more long-lived than, post-Archean plumes. Early cratons/continents probably formed above OUZOs as large volumes of basalt and komatiite were delivered for protracted periods by the mantle upwells (?plumes), allowing basal crustal anatexis to generate tonalite melt, along with the complementary generation of eclogite to pyroxenite restites (Bédard, 2006), periodic restite delamination, and coupled development of continental crust and sub-continental lithospheric mantle (SCLM). Periodic mixing and homogenization hindered the development of depleted mantle. Only after the establishment of true negative buoyancy-driven subduction, leading to the sequestration of the subducted slab at the core-mantle boundary, could the long-lasting depleted mantle develop (Bédard, 2018). When this transition took place in geological time is a debatable point.

Stern (2018) discussed the conditions to be satisfied for plate tectonics to operate. One of the important conditions is that the lithosphere must be denser than the underlying asthenophere, another one is that the subducting slab must be strong enough to remain intact in subduction zones. In Archean times the relative thickness of the oceanic crust (buoyant) is likely to be more and the relative thickness of the lithospheric mantle (dense) less, so that the density of the total lithosphere is likely to be less than the critical density necessary for sinking. Moreover, as the Archean mantle was hotter it would be weaker. The other important condition is the presence or development of zones of lithospheric weakness that are $\sim 1000 \mathrm{~km}$ long or longer. Large bolide impact may cause such zones of weakness in early Earth. Numerical modelling, taking these points into consideration, shows that plate tectonics could not have occurred in the Archean; or, if subduction did occur, it would be short-lived and of limited length (Stern, 2018, and references therein). In the early stage of the Earth history plate tectonic and single lid tectonic regimes may have alternated. This might have been the scenario at the Singhbhum Craton during Eoarchean.

Gerya et al. (2015) and Davaille et al. (2017) showed through thermo-mechanical modelling and experiments that subduction may be plume-induced. The arrival of a sufficiently large, hot and longlived mantle plume could render strong and dense negatively buoyant oceanic lithosphere weak enough to produce new self-sustaining subduction zones, which marked the beginning of plate tectonics. However, only the most energetic mantle plumes with large plume head and considerable temperature excess were able to sufficiently weaken the lithosphere enough to initiate subduction. The formation of such plume-driven oceanic plateaus in the Archean eon (Dey et al., 2017) could have triggered the onset of subduction and plate tectonics.

These points have to be taken into consideration in building up a geodynamic model for the evolution of the Singhbhum Craton. In particular, it is to be critically assessed whether the supra-subduction settings inferred for the supracrustal belts on the basis of geochemical attributes were short-lived and followed by further plume activities in a stagnant-lid set-up. A viable geodynamic model for the evolution of the Singhbhum Craton tightly constrained by geological, geochemical, isotopic and geochronological data is yet to come up.

The Singhbhum Craton had stabilized by 3.1-3.0 Ga. By this time it had emerged as a landmass so that paleosols could form on the surface and terrestrial siliciclastic sediments (Keonjhar Quartzite, Mahagiri Quartzite) could be deposited on top of them. The craton had cooled and had become sufficiently rigid to permit the formation the intracontinental rift basin in which the Dhanjori sediments and volcanics were laid down. The continental freeboard was at its maximum at this time (Bandopadhyay et al., 2010; Mazumder et al., 2012a). The anorogenic Mayurbhanj Granite ( $3.1 \mathrm{Ga})$, the Tamperkola Granite ( $2.8 \mathrm{Ga}$ ) and the Pallahara Gneiss ( 2./8 Ga) represent the last major granite magmatisms in the craton. The riftcontrolled sedimentation, volcanism and plutonism along the northern and eastern margin of the craton may be tied up with the early stage of basin development in the NSMB bordering the craton. The Chaibasa Formation in the NSMB overlies the the Dhanjoris with structural parallelism, but probably with a hiatus (Mukhopadhyay, 1976; Mazumder et al., 2012a, b). This represents a major marine transgression marking the beginning of the main stage of sedimentation and basin development. We speculate that the Kolhan sedimentation may also represent a marine incursion along the western edge of the craton. But the age of the Kolhans is not yet precisely defined, so this idea would remain in the realm of speculation. The formation of different sets of Newer Dolerite dyke swarms from 2.76 Ga to $<1.77$ Ga marks the end-Archean tensional regime in the craton, which may also be related to pre-orogenic stage of basin development in the NSMB. The Singhbum Craton remained a stable block since then and subsequent activity shifted to the Mesoproterozoic NSMB 
which curved round the craton in the north, east and west. In the south the Eastern Ghat Belt was sutured to the Singhbhum Craton probably during the Grenvillian orogeny or the Pan-African orogeny. At its waning stage a major shear zone (Eastern Indian Tectonic Zone) cut across the eastern boundary of the craton and the Mesoproterozoic orogenic belt.

\section{Acknowledgements}

We are grateful to Professor N. C. Pant for inviting us to write this paper. Many of our colleagues and students enhanced our understanding of the Singhbhum geology through stimulating discussions. Goutam Sarkar helped in preparing Figure 1.

\section{References}

Acharya, S., 1984, Stratigraphy and structural evolution of the rocks of the iron ore basin in Singhbhum-Orissa Iron Ore Province. In Proc. Sem. on Crustal evolution of the Indian shield and its bearing on metallogeny. Indian Journal Earth Science, v. pp. 19-28.

Acharyya, S., 1993, Greenstones from Singhbhum craton, their Archaean character, oceanic crustal affinity and tectonics. Proceedings of the Indian Academy of Sciences-Earth and Planetary Sciences India section A, v. 63, pp. 211-211.

Acharyya, S., Gupta, A., and Orihashi, Y., 2010a, New U-Pb zircon ages Paleo-Mesoproterozoic TTG gneisses of the Singhbhum Craton, eastern India. Geochemical Journal, v. 44, pp. 81-88.

Acharyya, S., Gupta, A., and Orihashi, Y., 2010b, NeoarcheanPaleoproterozoic stratigraphy of the Dhanjori basin, Singhbhum Craton, Eastern India: And recording of a few U-Pb zircon dates from its basal part. Journal of Asian Earth Sciences, v. 39, pp. 527-536.

Alvi, S.H., and Raza, M., 1991, Nature and magma type of Jagannathpur volcanics, Singhbhum, eastern India. Journal of Geological Society of India, v. 38, pp. 524-531.

Alvi, S.H., and Raza, M., 1992, Geochemical evidence for the volcanic arc tectonic setting of the Dhanjori volcanics, Singhbhum Craton, eastern India. Geological Magazine, v. 129, pp. 337-348.

Anhaeusser, C.R., 2010, Magmatic and structural characteristics of the ca. 3440 Ma Threespruit pluton, Barberton Mountain land, South Africa. American Journal of Science, v. 310, pp. 11361167.

Anhaeusser, C.R., Mason, R., Viljoen, M.J., and Viljoen, R.P., 1969, A reappraisal of some aspects of Precambrian shield geology. Bulletin Geological Society of America, v. 80, pp. 2175-2200.

Augé, T., Cocherie, A., Genna, A., Armstrong, R., Guerrot, C., Mukherjee, M.M., and Patra, R.N., 2003, Age of the Baula PGE mineralization (Orissa, India) and its implications concerning the Singhbhum Archaean nucleus. Precambrian Research, v. 121, pp. 85-101.

Baksi, A.K., Archibald, D., Sarkar, S., and Saha, A., 1987, ${ }^{40} \mathrm{Ar}-{ }^{39} \mathrm{Ar}$ incremental heating study of mineral separates from the early Archean east Indian craton: implications for the thermal history of a section of the Singbhum Granite batholithic complex. Canadian Journal of Earth Sciences, v. 24, pp. 1985-1993.

Ball, V., 1881, The geology of Manbhum and Singhbhum. Memoir of the Geological Survey of India, v. 18, pp. 61-150.

Bandyopadhyay, P., Chakrabarti, A., Deomurari, M., and Misra, S., 2001, 2.8 Ga old anorogenic granite-acid volcanics association from western margin of the Singhbhum-Orissa Craton, eastern India. Gondwana Research, v. 4, pp. 465-475.

Bandopadhyay, P. C., Eriksson, P. G. and Roberts, R. J., 2010, A vertic paleosol at the Archean-Proterozoic contact from the Singhbhum0Orissa craton, eastern India. Precambrian Reseach, v. 177 , pp. $277-290$.

Bandopadhyay, P. C., and Sengupta, S., 2004, The Paleoproterozoic Supracrustal Kolhan Group in Singhbhum Craton, India and the Indo-African Supercontinent, Gondwana Research (Gondwana Newsletter Section) v. 7, pp. 1228-1235.

Banerjee, P. K., 1972, Geology and geochemistry of the Sukinda ultramafic field, Cuttack District, Orissa. Memoir of the Geological Survey of India, v. 103, pp. 171.

Banerjee, P. K., 1982, Stratigraphy, petrology, and geochemistry of some Precambrian basic volcanic and associated rocks of Singhbhum District, Bihar, and Mayurbhanj and Keonjhar districts, Orissa. Memoir, Geological Survey of India, v. 111, pp. 1-54.

Banerjee, P. K., and Ghosh, S. K., 1994, Is the Simlipal Complex a product of shallow plume tectonics? Journal of the Geological Society of India, v. 43, pp. 353-359.

Banerjee, M., Ray, J., Nandy, S., Manikyamba, C., Paul, M., Chakraborty, D., and Eslami, A., 2016, Experimental studies to constrain parental magma of Malangtoli volcanics from Singhbhum craton of the eastern Indian shield. Journal of the Geological Society of India, v. 88, pp. 245-255.

Banerjee, S., and Matin, A., 2013, Evolution of microstructures in Precambrian shear zones: An example from eastern India. Journal of Structural Geology, v. 50, pp. 199-208.

Banerjee, S., Richards, I., Ferguson, K., Gregory, R.T., and Basu, A.R., 2009, Archean fluid-rock interaction: Oxygen and hydrogen isotope ratio from Iron Ore Group, India. Geochimica Cosmochimica Acta, v. 72, pp. A48.

Banerji, A. K., 1977, On the Precambrian banded iron-formations and the manganese ores or the Singhbhum region, eastern India. Economic Geology, v. 72, pp. 90-98.

Basu, A., Bandyopadhyay, P., Chakrabarti, R., and Zou, H., 2008, Large 3.4 ga algoma-type BIF in the Eastern Indian Craton. Geochimica Cosmochimica Acta Supplement, v. 72, pp. A59.

Basu, A., Sharma, M., and Premo, W., 1996, U-Pb age of an older Metamorphic Group mica schist: earliest terrain of the eastern Indian Craton. Recent Researches in Geology and Geophysics of the Precambrians, Hindustan Publication Corporation, New Delhi, India, v. 16, pp. 93-102.

Bauer, A.M., Fisher, C.M., Vervoort, J.D., and Bowring, S.A., 2017, Coupled zircon $\mathrm{Lu}-\mathrm{Hf}$ and $\mathrm{U}-\mathrm{Pb}$ isotopic analyses of the oldest terrestrial crust, the $>4.03 \mathrm{Ga}$ Acasta Gneiss Complex. Earth and Planetary Science Letters, v. 458, pp. 37-48.

Bédard, J. H., 2006, A catalytic delamination-driven model for coupled genesis of Archean crust and subcontinental lithospheric mantle. Geochimica Cosmochimica Acta, v. 70, pp. 1188-1214.

Bédard, J.H., 2018, Stagnant lids and mantle overturns: Implications for Archaean tectonics, magmagenesis, crustal growth, mantle evolution, and the start of plate tectonics. Geoscience Frontiers, v. 9, pp. 19-49.

Bekker, A., Slack, J.F., Planavsky, N., Krapez, B., Hofmann, A., Konhauser, K.O., and Rouxel, O.J., 2010, Iron formation: the sedimentary product of a complex interplay among mantle, tectonic, oceanic, and biospheric processes. Economic Geology, v. 105 , pp. $467-508$.

Bennett, V.C., Nutman, A.P., and McCulloch, M.T., 1993, Nd isotopic evidence for transient, highly depleted mantle reservoirs in the early history of the Earth. Earth and Planetary Science Letters, v. 119, pp. 299-317.

Beukes, N., 2004, Biogeochemistry: Early options in photosynthesis. Nature, v. 431, pp. 522.

Beukes, N., and Klein, C., 1992, Models for iron-formation 
deposition. In: J.W. Schopf, and Klein, C. (Editor), The Proterozoic biosphere. Cambridge University Press, Cambridge, UK. pp. 147-151.

Beukes, N.J., Mukhopadhyay, J., and Gutzmer, J., 2008, Genesis of high-grade iron ores of the Archean Iron Ore Group around Noamundi, India. Economic Geology, v. 103, pp. 365-386.

Bhattacharya, H., Chakraborty, I. and Ghosh, K. K., 2007, Geochemistry of some banded iron-formations of the archean supracrustals, Jharkhand-Orissa region, India. Journal of Earth System Science, v. 116, pp. 245-259.

Bhattacharya, A., Das, H.H., Bell, E., Bhattacharya, A., Chatterjee, N., Saha, L., and Dutt, A. 2016, Restoration of Late NeoarcheanEarly Cambrian tectonics in the Rengali orogen and its environs (eastern India): The Antarctic connection. Lithos, v. 263, pp. 190212.

Bhattacharya, H., and Mahapatra, S., 2008, Evolution of the Proterozoic rift margin sediments-North Singhbhum Mobile belt, Jharkhand-Orissa, India. Precambrian Research, v. 162, pp. 302-316.

Bhattacharyya, D. S., and Sanyal, P., 1988, The Singhbhum orogen Its structure and stratigraphy. In, Precmbrian of the Eastern Indian Shield, Ed. - Mukhopadhyay, D. Memoir Geological Society of India, v. 8, pp. 85-111.

Blackburn, W., and Srivastava, D., 1994, Geochemistry and tectonic significance of the Ongarbira metavolcanic rocks, Singhbhum District, India. Precambrian Research, v. 67, pp. 181-206.

Blichert-Toft, J., and Albarède, F., 2008, Hafnium isotopes in Jack Hills zircons and the formation of the Hadean crust. Earth and Planetary Science Letters, v. 265, pp. 686-702.

Bose, M.K., 2009, Precambrian mafic magmatism in the Singhbhum craton, eastern India. Journal of the Geological Society of India, v. 73, pp. 13-35.

Bose, S., Guha, S., Ghosh, G., Das, K., and Mukhopadhyay, J., 2015, Tectonic juxtaposition of crust and continental growth during orogenesis: example from the Rengali Province, eastern India. Geoscience Frontiers, v. 6, 537-555.

Bowring, S.A., and Housh, T., 1995, The Earth's early evolution. Science, v. 269, pp. 1535-1540.

Bowring, S.A., and Williams, I.S., 1999, Priscoan (4.00-4.03 Ga) orthogneisses from northwestern Canada. Contributions to Mineralogy and Petrology, v. 134, pp. 3-16.

Bowring, S. A., Williams, I. S. and Compston, W., 1989, 3.96 Ga gneisses from the slave province, Northwest Territories, Canadian Geology, v. 17, pp. 971-975.

Caro, G., Bourdon, B., Birck, J.L., and Moorbath, S., 2006, Highprecision ${ }^{142} \mathrm{Nd} /{ }^{144} \mathrm{Nd}$ measurements in terrestrial rocks: constraints on the early differentiation of the Earth's mantle. Geochimica Cosmochimica Acta, v. 70, pp. 164-191.

Cates, N.L., Ziegler, K., Schmitt, A.K., and Mojzsis, S.J., 2013, Reduced, reused and recycled: detrital zircons define a maximum age for the Eoarchean (ca. 3750-3780 Ma) Nuvvuagittuq Supracrustal Belt, Québec (Canada). Earth and Planetary Science Letters, v. 362, pp. 283-293.

Chakraborty, K. L., and Majumder, T., 1986, Geological aspects of Banded Iron Formations of Bihar and Orissa; Journal of the Geological Society of India, v. 28, pp. 109-133.

Chakraborti, T.M., Ray, A., Deb, G.K., Upadhyay, D. and Chakrabarti, R., 2019, Evidence of crustal reworking in the Mesoarchean: Insights from geochemical, U-Pb zircon and $\mathrm{Nd}$ isotopic study of a 3.08-3.12 Ga ferro-potassic granite-gneiss from north-eastern margin of Singhbhum Craton, India. Lithos, v. 330-331, pp. 1634.

Chakraborty, T, Upadhyay, D., Ranjan, S., Pruseth, K. L., Nanda, J. K. 2019. The geological evolution of the Gangpur Schist Belt: constraints on the formation of the greater Indian landmass in the Proterozoic. Journal of Metamorphic Geology, v. 37, pp. 113151.

Chatterjee, N., Banerjee, M., Bhattacharya, A. and Maji, A., 2010, Monazite chronology, metamorphism-anatexis and tectonic relevance of the mid-Neoproterozoic Eastern Indian Tectonic Zone. Precambrian Research, v. 179, pp. 99-120.

Chattopadhyay, S., Upadhyay, D., Nanda, J.K., Mezger, K., Pruseth, K.L. and Berndt, J., 2015, Proto-India was a part of Rodinia: evidence from Grenville-age suturing of the Eastern Ghats Province with the Paleoarchean Singhbhum Craton. Precambrian Research, v. 266, pp. 506-529.

Chaudhuri, T., Mazumder, R., and Arima, M., 2015, Petrography and geochemistry of Mesoarchaean komatiites from the eastern Iron Ore belt, Singhbhum craton, India, and its similarity with 'Barberton type komatiite'. Journal of African Earth Sciences, v. 101, pp. 135-147.

Chaudhuri, T., Satish-Kumar, M., Mazumder, R., and Biswas, S., 2017, Geochemistry and Sm-Nd isotopic characteristics of the Paleoarchean Komatiites from Singhbhum Craton, Eastern India and their implications. Precambrian Research, v. 298, pp. 385402.

Chaudhuri, T., Wan, Y., Mazumder, R., Ma, M., and Liu, D., 2018, Evidence of Enriched, Hadean Mantle Reservoir from 4.2-4.0 Ga zircon xenocrysts from Paleoarchean TTGs of the Singhbhum Craton, Eastern India. Scientific reports, v. 8, 7069. DOI:10.1038/ s41598-018-25494-6.

Collins, W.J, Van Kranendonk, M.J., and Teyssier, C., 1998, Partial convective overturn of Archaean crust in the east Pilbara Craton, Western Australia: driving mechanisms and tectonic implications. Journal of Structural Geology, v. 20, pp. 1405-1424.

Compston, W., and Pidgeon, R. T., 1986, Jack Hills, evidence of more very old detrital zircons in Western Australia. Nature, 321, 766-769.

Crowe, W.A., Nash, C.R., Harris, L.B., Leeming, P.M., and Rankin, L.R., 2003, The Geology of the Rengali Province: implications for the tectonic development of Northern Orissa, India. Journal of Asian Earth Sciences, v. 21, pp. 697-710.

Dangwal, M., 1987, Structural evolution of Dhanjori greenstone belt, District Singhbhum, Bihar, India. M. Tech. Dissertation in Applied Geology, University of Roorkee, 62p.

Davaille, A., Smrekar, S. E. and Tomlinson, S., 2017, Experimental and observational evidence for plume-induced subduction on Venus. Nature Geoscience, v. 10, pp. 349-355.

De, S., Mazumder, R., Ohta, T., Hegner, E., Yamada, K., Bhattacharyya, T., Chiarenzelli, J., Altermann, W., and Arima, M., 2015, Geochemical and Sm-Nd isotopic characteristics of the Late Archaean-Palaeoproterozoic Dhanjori and Chaibasa metasedimentary rocks, Singhbhum craton, E. India: Implications for provenance, and contemporary basin tectonics. Precambrian Research, v. 256, pp. 62-78.

Deb, G., 1999, Evolution of Dhanjori volcano-sedimentary rocks in the north Singhbhum fold belt - A reappraisal. Indian Minerals, v. 53, pp. 25-36.

Dey, K.N., 1991, The older raft tonalite of Rairangapur and its bearing on Precambrian stratigraphy of the Singhbhum craton. Indian Journal of Geology, v. 63, pp. 261-274.

Dey, S., Topno, A., Liu, Y., and Zong, K., 2017, Generation and evolution of Palaeoarchaean continental crust in the central part of the Singhbhum craton, eastern India. Precambrian Research, v. 298, pp. 268-291.

Dunn, J.A., 1929, The geology of north Singhbhum including parts of Ranchi and Manbhum districts. Memoir of the Geological Survey of India, v. 54, pp. 166. 
Dunn, J.A., 1940, The stratigraphy of south Singhbhum. Memoir of the Geological Survey of India, v. 63, pp. 303-369.

Dunn, J.A., and Dey, A.K., 1942, The geology and petrology of eastern Singhbhum and surrounding areas. Memoir Geological Survey of India, v. 69, pp. 281-450.

Duo, J., Wen, C.Q., Guo, J. C., Fan, X.P. and Li, X.W. 2007, 4.1 Ga old detrital zircon in western Tibet of China. Bulletin Chinese Science, v. 52, pp. 23-26.

Elkins-Tanton, L.T., 2012, Magma Oceans in the Inner Solar System. Ann. Rev. Earth and Planetary Science, v. 40, pp.113139.

Ernst, R. E., 2014, Large Igneous Provinces. Cambridge University Press, Cambridge, pp. 653.

Fisher, C.M., and Vervoort, J.D., 2018, Using the magmatic record to constrain the growth of continental crust-The Eoarchean zircon Hf record of Greenland. Earth and Planetary Science Letters, v. 488, pp. 79-91.

Furnes, H., Rosing, M., Dilek, Y., and De Wit, M., 2009, Isua supracrustal belt (Greenland)—A vestige of a $3.8 \mathrm{Ga}$ suprasubduction zone ophiolite, and the implications for Archean geology. Lithos, v. 113, pp. 115-132.

Gaal, G., 1964, Precambrian flysch and molasse-Tectonics and sedimentation around Rakha mines and Jaikan in Singhbhum district, Bihar, India. Proceedings 22th International Geological Congress, Abstract, p. 331-356.

Gerya, T., Stern, R. J., Baes, M., Sobolev, S., and Whattam, S., 2015, Plume-induced subduction initiation triggered plate tectonics on Earth. Nature, v. 527, pp. 221-225.

Ghosh, D., Sarkar, S. N., Saha, A. K., and Ray, S. L., 1996, New insights on the early Archaean crustal evolution in eastern India: Re-evaluation of lead-lead, samarium-neodymium and rubidiumstrontium geochronology. Indian Minerals, v. 50, pp. 175-188.

Ghosh, G., Bose, S., Das, K., Dasgupta, A., Yamamoto, T., Hayasakam Y., Chakrabarti, K., Mukhopadhyay, J., 2016a, Transpression and juxtaposition of middle crust over upper crust forming a crustal scale flower structure: insight from structural, fabric, and kinematic studies from the Rengali Province, eastern India. Journal of Structural Geology, v. 83, pp. 156-179.

Ghosh, G., Bose, S., Guha, S., Mukhopadhyay, J., Aich, S., 2010a, Remobilization of the southern margin of the Singhbhum Craton, eastern India during the Eastern Ghats orogeny. Indian Journal of Geology, v. 80, pp. 97-114.

Ghosh, G., Ghosh, B., and Mukhopadhyay, J., 2015, PalaeoarchaeanMesoproterozoic sedimentation and tectonics along the westnorthwestern margin of the Singhbhum Granite body, eastern India: a synthesis. Geological Society of London, Memoirs, v. 43, pp. 121-138.

Ghosh, G., Kumari, S., Patil, S.K., Mukhopadhyay, J., and Ray, A., 2010b, Superposed deformation fabrics in the Precambrian metabasic rocks of the Iron Ore Group, Singhbhum craton, Eastern India: Evidences from anisotropy of magnetic susceptibility studies. Journal of Structural Geology, v. 32, pp. 249-261.

Ghosh, G., and Mukhopadhyay, J., 2007, Reappraisal of the structure of the Western Iron Ore Group, Singhbhum craton, eastern India: Implications for the exploration of BIF-hosted iron ore deposits. Gondwana Research, v. 12, pp. 525-532.

Ghosh, K. K. and Ray, J. S., 1994, Some observations on geochemistry and tectonic setting of Dhanjori metavolcanics of the eastern Indian Shield. Indian Journal of Geology, v. 66, pp. 279-295.

Ghosh, R., Vermeesch, P., Gain, D., Mondal, R., 2019, Genetic relationship among komatiites and associated basalts in the Badampahar greenstone belt (3.25-3.10 Ga), Singhbhum Craton, Eastern India. Precambrian Research, v. 327, pp. 196-211.

Ghosh, S., and Sengupta, S., 1987, Structural history of the
Singhbhum shear zone in relation to the northern belt. Geological Evolution of Peninsular, India, Researches in Geology, v. 13, pp. 31-44.

Ghosh, S., De, S. and Mukhopadhyay, J., 2016b, Provenance of $>2.8$ Ga Keonjhar Quartzite, Singhbhum Craton, Eastern India: Implications for the nature of Mesoarchean upper crust and geodynamics. Indian Journal of Geology, v. 124, pp. 331-351.

Goswami, J., Mishra, S., Wiedenbeck, M., Ray, S., and Saha, A., 1995, 3.55 Ga old zircon from Singhbhum-Orissa iron ore craton, eastern India. Current Science, v. pp. 1008-1012.

Grant, P.R., Murty, V.N. and Sengupta, S., 1980, The first record of stromatolites from the Koira Group (Iron Ore Series), Precambrian of Bihar-Orissa, India. Geological Survey of India, Special Publlication, v. 44, pp. 49-53.

Griffin, W. L., Belousova, E. A., O’Neill, C., O’Reilly, S. Y., Malkovets, V., Pearson, N. J., Spetsius, S. and Wilde, S. A., 2014, The world turns over: Hadean-Archean crust-mantle evolution. Lithos, v. 189, pp. 2-15.

Guitreau, M., Blichert-Toft, J., Martin, H., Mojzsis, S.J., and Albarède, F., 2012, Hafnium isotope evidence from Archean granitic rocks for deep-mantle origin of continental crust. Earth and Planetary Science Letters, v. 337-338, pp. 211-223.

Gupta, A., 1985, Stratigraphy and petrochemistry of Dhanjori greenstone belt, eastern India. Quarternary Journal of Geological Mining and Metallurgical Society of India, v. 57, pp. 248-263.

Gutzmer, J., Mukhopadhyay, J., Beukes, N., Pack, A., Hayashi, K., and Sharp, Z., 2006, Oxygen isotope composition of hematite and genesis of high-grade BIF-hosted iron ores. Memoirs of Geological Society of America, v. 198, pp. 257-268.

Harrison, T.M., 2009, The Hadean crust: evidence from> 4 Ga zircons. Annual Review of Earth and Planetary Sciences, v. 37, pp. 479505.

Hawkesworth, C.J., Cawood, P.A., Dhuime, B., Kemp, T.I.S., 2017, Earth's Continental Lithosphere through Time. Annual Review of Earth and Planetary Science, v. 45, pp. 169-198.

Hawkesworth, C.J., Dhuime, B., Pietranik, A.B., Cawood, P.A., Kemp, A.I.S., Storey, C.D., 2010, The generation and evolution of the continental crust. Journal of the Geological Society of London, v. 167 , pp. 229-248.

Hickman, A.H., 1984, Archaean diapirism in the Pilbara Block, Western Australia. In: Kröner, A., Greiling, R. (Eds.), Precambrian Tectonics Illustrated. E. Schweizerbart'sche, Stuttgart, Germany, pp. 113-127.

Hoffmann, J.E., Kröner, A., Hegner, E., Viehmann, S., Xie, H., Iaccheri, L.M., Schneider, K.P., Hofmann, A., Wong, J., and Geng, H., 2016, Source composition, fractional crystallization and magma mixing processes in the 3.48-3.43 Ga Tsawela tonalite suite (Ancient Gneiss Complex, Swaziland)-Implications for Palaeoarchaean geodynamics. Precambrian Research, v. 276, pp. 43-66.

Hofmann, A., and Mazumder, R., 2015, A review of the current status of the Older Metamorphic Group and Older Metamorphic Tonalite Gneiss: insights into the Palaeoarchaean history of the Singhbhum craton, India. Memoirs of Geological Society, London, v. 43, pp. 103-107.

Hoffmann, J.E., Nagel, T.J., Muenker, C., Næraa, T., and Rosing, M.T., 2014, Constraining the process of Eoarchean TTG formation in the Itsaq Gneiss Complex, southern West Greenland. Earth and Planetary Science Letters, v. 388, pp. 374-386.

Hopkins, M., Harrison, T.M., and Manning, C.E., 2008, Low heat flow inferred from $>4$ Gyr zircons suggests Hadean plate boundary interactions. Nature, v. 456, pp. 493-496.

Iizuka, T., Horie, K., Komiya, T., Maruyama, S., Hirata, T., Hidaka, H., and Windley, B.F., 2006, 4.2 Ga zircon xenocryst in an Acasta 
gneiss from northwestern Canada: Evidence for early continental crust. Geology, v. 34, pp. 245-248.

Iizuka, T., Komiya, T., Johnson, S.P., Kon, Y., Maruyama, S., and Hirata, T., 2009, Reworking of Hadean crust in the Acasta gneisses, northwestern Canada: evidence from in-situ Lu-Hf isotope analysis of zircon. Chemical Geology, v. 259, pp. 230239.

Iizuka, T., Komiya, T., Ueno, Y., Katayama, I., Uehara, Y., Maruyama, S., Hirata, T., Johnson, S.P., and Dunkley, D.J., 2007, Geology and zircon geochronology of the Acasta Gneiss Complex, northwestern Canada: new constraints on its tectonothermal history. Precambrian Research, v. 153, pp. 179-208.

Iyenger, S. V. P., and Banerjee, S., 1964, Magmatic phases associated with the Precambrian tectonics of Mayurbhanj district, Orissa. India. Report, 22nd Internatational Geological Congress, v. 10, pp. 515-538.

Iyenger, S.V.P., Chandy, K.C., and Narayanswami, R., 1981, Geohronology and Rb-Sr systematicsof the igneous rocks of the Simlipal Complex, Orissa. Indian Journal of Earth Science, v. 8, pp. 61-65.

Iyengar, S.V.P. and Murthy, Y.G.K., 1982, The evolution of Archaean -Proterozoic crust in parts of Bihar and Orissa, eastern India, Records of Geological Survey of India, v. 112, pp. 1-6.

Jacobsen, S.B., and Pimentel-Klose, M.R., 1988, A Nd isotopic study of the Hamersley and Michipicoten banded iron formations: the source of REE and Fe in Archean oceans. Earth and Planetary Science Letters, v. 87, pp. 29-44.

Jena, B.K., and Behera, U.K., 2000, The oldest supracrustal belt from Singhbhum craton and its possible correlation; Geological Survey of India Special Publication, v. 57, pp. 106-121.

Jenner, F., Bennett, V., Nutman, A., Friend, C., Norman, M., and Yaxley, G., 2009, Evidence for subduction at 3.8 Ga: geochemistry of arc-like metabasalts from the southern edge of the Isua Supracrustal Belt. Chemical Geology, v. 261, pp. 82-97.

Johnson, T.E., Brown, M., Gardiner, N.J., Kirkland, C.L., and Smithies, R.H., 2017, Earth's first stable continents did not form by subduction. Nature, v. 543, pp. 239-242.

Johnson, T.E., Brown, M., Kaus, B.J., and VanTongeren, J.A., 2014, Delamination and recycling of Archaean crust caused by gravitational instabilities. Nature Geoscience, v. 7, pp. 47-52.

Jones, H.C., 1934, The iron ore deposit of Bihar and Orissa. Memoir Geological Survey of India, v. 63, pp. 167-302.

Joy, S., and Saha, D., 1998, Influence of micaceous impurity on dynamically recrystallized quartz c-axis fabric in LS tectonites from the Singhbhum Shear Zone and its footwall, Eastern India. Journal of structural geology, v. 20, pp. 1509-1520.

Joy, S., and Saha, D., 2000, Dynamically recrystallised quartz c-axis fabrics in greenschist facies quartzites, Singhbhum shear zone and its footwall, eastern India-influence of high fluid activity. Journal of Structural Geology, v. 22, pp. 777-793.

Kaczmarek, M.A., Reddy, S.M., Nutman, A.P., Friend, C.R., and Bennett, V.C., 2016, Earth's oldest mantle fabrics indicate Eoarchaean subduction. Nature communications, Article No. 10655, pp.1-7.

Kappler, A., Pasquero, C., Konhauser, K.O., and Newman, D.K., 2005, Deposition of banded iron formations by anoxygenic phototrophic Fe (II)-oxidizing bacteria. Geology, v. 33, pp. 865868.

Kemp, A., Wilde, S., Hawkesworth, C., Coath, C., Nemchin, A., Pidgeon, R., Vervoort, J., and DuFrane, S., 2010, Hadean crustal evolution revisited: new constraints from $\mathrm{Pb}-\mathrm{Hf}$ isotope systematics of the Jack Hills zircons. Earth and Planetary Science Letters, v. 296, pp. 45-56.

Khatun, S., Mondal, S.K., Zhou, M.F., Balaram, V., and Prichard,
H.M., 2014, Platinum-group element (PGE) geochemistry of Mesoarchean ultramafic-mafic cumulate rocks and chromitites from the Nuasahi Massif, Singhbhum Craton (India). Lithos, v. 205, pp. 322-340.

Klein, C., 2005, Some Precambrian banded iron-formations (BIFs) from around the world: Their age, geologic setting, mineralogy, metamorphism, geochemistry, and origins. American Mineralogist, v. 90, pp. 1473-1499.

Kröner, A., Hoffmann, J.E., Xie, H., Münker, C., Hegner, E., Wan, Y., Hofmann, A., Liu, D., and Yang, J., 2014, Generation of early Archaean grey gneisses through melting of older crust in the eastern Kaapvaal craton, southern Africa. Precambrian Research, v. 255, pp. 833-846.

Kröner, A., Hoffmann, J.E., Xie, H., Wu, F., Münker, C., Hegner, E., Wong, J., Wan, Y., and Liu, D., 2013, Generation of early Archaean felsic greenstone volcanic rocks through crustal melting in the Kaapvaal, craton, southern Africa. Earth and Planetary Science Letters, v. 381, pp. 188-197.

Kumar, A., Parasharamalu, V., Ravi Shankar and Besse, J., 2017, Evidence for a Neoarchean LIP in the Singhbhum craton, eastern India: Implications to Vaalbara supercontinent. Precambrian Research, v. 292, pp. 163-174.

Mahalik, N. K., 1987, Geology of rocks lying between Gangpur Group and Iron Ore Group of the Horse shoe syncline in North Orissa. Indian Journal of Earth Sciences, v. 14, pp. 73-83.

Mahalik, N. K., 1994, Geology of the contact between the Eastern Ghats Belt and North Orissa Carton, India. Journal of the Geological Society of India, v. 44, pp. 41-51.

Mahapatro, S., Pant, N., Bhowmik, S., Tripathy, A., and Nanda, J., 2012, Archaean granulite facies metamorphism at the Singhbhum Craton-Eastern Ghats Mobile Belt interface: implication for the Ur supercontinent assembly. Geological Journal, v. 47, pp. 312333.

Maithy, P., and Avasthy, R., 1982, Record of Biological Remains from the Iron-Ore Supergroup, Orissa, India. Journal of the Geological Society of India, v. 23, pp. 307-310.

Majumder, T., 1985, Environment and petrogenesis of the Precambrian Banded Iron Formation of the Iron Ore Group, eastern India. Geological Survey of Finland, Bulletin v. 331, pp. 201-213.

Majumder, T., and Chakraborty, K. L., 1977, Primary sedimentary structures in the banded iron-formation of Orissa, India. Sedimentary Geology, v. 19, pp. 287-300.

Mallik, A.K., and Sarkar, A., 1994, Geochronology and geochemistry of mafic dykes from the Precambrians of Keonjhar, Orissa. Indian Minerals, v. 48, pp. 13-24.

Mandal, N., Mitra, A. K., Misra, S., and Chakraborty, C, 2006, Is the outcrop topology of dolerite dikes of the Precambrian Singhbhum Craton fractal? Journal of Asian Earth Sciences, v. 115, pp. 643660.

Manikyamba, C., Ray, J., Ganguly, S., Singh, M.R., Santosh, M., Saha, A., and Satyanarayanan, M., 2015, Boninitic metavolcanic rocks and island arc tholeiites from the Older Metamorphic Group (OMG) of Singhbhum Craton, eastern India: Geochemical evidence for Archean subduction processes. Precambrian Research, v. 271, pp. 138-159.

Marchi, S., Bottke, W. F., Elkins-Tanton, L. T., Bierhaus, M., Wuennemann, K., Morbidelli, A. and Kring, D. A., 2014, Widespread mixing and burial of Earth's Hadean crust by asteroid impacts. Nature, v. 511, 578.

Marshak, S., Alkmim, F., and Jordt-Evangelista, H., 1992, Proterozoic crustal extension and the generation of dome-and-keel structure in an Archaean granite-greenstone terrane. Nature, v. 357, pp. 491-493.

Matin, A., Banerjee, S., Gupta, C.D., and Banerjee, N., 2012, 
Progressive deformation across a ductile shear zone: an example from the Singhbhum Shear Zone, eastern India. International Geology Review, v. 54, pp. 290-301.

Mazumder, R., 2006, Large Igneous Provinces, Mantle Plumes and Uplift: A Case Study from the Dhanjori Formation, India. http:// www.MantlePlumes.org.

Mazumder, R., and Arima, M., 2009, Implication of mafic magmatism in an intracontinental rift setting: a case study from the Paleoproterozoic Dhanjori formation, Singhbhum crustal province, India. The Journal of Geology, v. 117, pp. 455-466.

Mazumder, R., Eriksson, P.G., De, S., Bumby, A.J., Lenhardt, N., 2012a, Palaeoproterozoic sedimentation on the Singhbhum craton: global context and comparisonwith Kaapvaal. In: Mazumder, R., Saha, D. (Eds.), Palaeoproterozoic of India. Geological Society, London, Special Publications, v. 365, 51-76.

Mazumder, R. and Sarkar, S., 2004, Sedimentation history of the Palaeoproterozoic Dhanjori Formation, Singhbhum, eastern India. Precambrian Research, v. 130, pp. 267-287.

Mazumder, R., Van Loon, A. J., Mallik, L., Reddy, S. M., Arima, M., Altermann, W., Eriksson, P. G. and De, S., 2012b, MesoarchaeanPalaeoproterozoic stratigraphic record of the Singhbhum crustal province, eastern India: a synthesis. In, Mazumder, R. and Saha, D. (Eds.), Palaeoproterozoic of India, Geological Society, London, Special Publications, v. 365, pp. 31-49.

Mazumder, S.K., 1996, Precambrian geology of peninsular eastern India. Indian Minerals, v. 50, pp.139-174.

Miller, S.R., Mueller, P.A., Meert, J.G., Kamenov, G.D., Pivarunas, A.F., Sinha, A.K., and Pandit, M.K., 2018, Detrital zircons reveal evidence of Hadean crust in the Singhbhum craton, India. The Journal of Geology, v. 126, pp. 541-552.

Mir, A.R., Alvi, S.H., and Balaram, V., 2010, Geochemistry of mafic dikes in the Singhbhum Orissa craton: implications for subduction-related metasomatism of the mantle beneath the eastern Indian craton. International Geology Review, v. 52, pp. 79-94.

Mir, A. R., Alvi, S. H., Balaram, V., Bhat, F. A., Sumira Z., and Dar, S. A., 2013, A subduction zone geochemical characteristic of the newer dolerite dykes in the Singhbhum Craton, Eastern India. International Research Journal of Geology and Mining (22766618), v. 3, pp. 213-223.

Misra, S., 1999, The Mayurbhanj Granite: Its nature, tectonic setting, mode of emplacement and pressure-temperature of magma generation. Indian Journal of Geology, v. 71, pp. 33-52.

Mishra, S., Deomurari, M., Wiedenbeck, M., Goswami, J., Ray, S., and Saha, A., 1999, 207Pb/206Pb zircon ages and the evolution of the Singhbhum Craton, eastern India: an ion microprobe study. Precambrian Research, v. 93, pp. 139-151.

Misra, S., and Johnson, P.T., 2005, Geochronological constraints on evolution of Singhbhum mobile belt and associated basic volcanics of eastern Indian shield. Gondwana Research, v. 8, pp. 129-142.

Misra, S., Moitra, S., Bhattacharya, S., and Sivaraman, T, V., 2000, Archean granitoids at the contact of Eastern Ghat granulite belt and Singhbhum-Orissa craton in Bhuban Rengali Sector, Orissa, India. Gondwana Research, v. 3, pp. 206-213.

Misra, S., Sarkar, S.S., and Ghosh, S., 2002, Evolution of Mayurbhanj Granite Pluton, eastern Singhbhum, India: a case study of petrogenesis of an A-type granite in bimodal association. Journal of Asian Earth Sciences, v. 20, pp. 965-989.

Mondal, S.K., 2009, Chromite and PGE deposits of Mesoarchaean ultramafic-mafic suites within the greenstone belts of the Singhbhum Craton, India: Implications for mantle heterogeneity and tectonic setting. Journal of the Geological Society of India, v. 73 , pp. 36-51.
Mondal, S. K., Frei, R. and Ripley, E. M., 2007, Os isotope systematics of Mesoarchean chromitite-PGE deposits in the Singhbhum Craton (India): Implications for the evolution of lithospheric mantle. Chemical Geology, v. 244, pp. 391-408.

Mondal, S.K., Khatun, S., Prichard, H.M., Satyanarayanan, M., and Kumar, G.R., 2019, Platinum-group element geochemistry of boninite-derived Mesoarchean chromitites and ultramafic-mafic cumulate rocks from the Sukinda Massif (Orissa, India). Ore Geology Reviews, v. 104, pp. 722-744.

Mondal, S.K., Ripley, E.M., Li, C. and Frei, R., 2006, The genesis of Archean chromitites from the Nuasahi and Sukinda massifs in the SunghbhumCraton, India. Precambrian Research, v. 148, pp. 45-66.

Mondal, S.K., Ripley, E.M., Zhou, M.F. and Frei, R., 2004, Major, trace and platinum-group elements geochemistry of $3.2 \mathrm{Ga}$ Nuasahi ultramafic-mafic massifs in Archean greenstone belts of the Singhbhum Craton, Eastern India: Implications for Archean mantle. In: J.G. Shellnutt, M.F. Zhou And K.N.Pang (Eds.), 'Recent advances In magmatic ore systems in mafic-ultramafic rocks'. Proceedings IGCP Project 479, Hong KongWorkshop, pp. 114-117.

Mondal, S.K. and Zhou, M.F., 2010, Enrichment of PGE through interaction of evolved boninitic magmas with early formed cumulates in a gabbro-breccia zone of the Mesoarchean Nuasahi Massif (eastern India). Mineralium Deposita, v. 45, pp. 69-91.

Moorbath, S., Taylor, P. and Jones, N., 1986, Dating the oldest terrestrial rocks-fact and fiction. Chemical Geology, v. 57, pp. 63-86.

Moorbath, S., and Whitehouse, M.J., 1996, Sm-Nd isotopic data and Earth's evolution (Comments on article by Bowring and Housh, 1995 Nd Response). Science, 273, 1878-1879.

Moyen, J.F., 2011, The composite Archaean grey gneisses: petrological significance, and evidence for a non-unique tectonic setting for Archaean crustal growth. Lithos, v. 123, pp. 21-36.

Mukherji, A., Chaudhuri, A.K., Mamtani, M.A., 2004, Regional scale strain variations in Banded Iron Formations of eastern India: results from anisotropy of magnetic susceptibility studies. Journal of Structural Geology, v. 26, pp. 2175-2189.

Mukhopadhyay, D., 1976, Precambrian stratigraphy of Singhbhumthe problems and a prospect. Indian Journal of Earth Sciences, v. 3, pp. 208-219.

Mukhopadhyay, D., 2001, The Archaean nucleus of Singhbhum: the present state of knowledge. Gondwana Research, v. 4, pp. 307318.

Mukhopadhyay, D., Bhattacharya, T., Chakraborty, T., and Dey, A.K., 1990, Structural pattern in the Precambrian rocks of SonuaLotapahar region, North Singhbhum, eastern India. Proceedings of the Indian Academy of Sciences - Earth and Planetary Sciences, v. 99, pp. 249-268.

Mukhopadhyay, D and Deb, G. K., 1995, Structural and textural development in Singhbhum shear zone, eastern India. Proceedings of Indian Academy of Sciences (Earth and Planetary Scinces), v. 104, pp. 385-405.

Mukhopadhyay, D., Dasgupta, S., and Dhar, K., 1980, Basement slices in the cover rocks of North Singhbhum near Hakegora and Jaikan. Journal of the Geological Society of India, v. 21, pp. 286-294.

Mukhopadhyay, D., and Dutta, D. R., 1983, Structures in the Roro ultramafics and their country rocks, Singhbhum district, Bihar. Structure and tectonics of Precambrian Rocks of India. Recent Researches in Geology, Hindustan Publishing Corporation, New Delhi, v. 10, pp. 98-109.

Mukhopadhyay, J., Beukes, N., Armstrong, R., Zimmermann, U., Ghosh, G., and Medda, R., 2008c, Dating the oldest greenstone in India: a 3.51-Ga precise U-Pb SHRIMP zircon age for dacitic 
lava of the southern Iron Ore Group, Singhbhum craton. The Journal of Geology, v. 116, pp. 449-461.

Mukhopadhyay, J., Ghosh, G., Beukes, N., and Gutzmer, J., 2007, Precambrian colluvial iron ores in the Singhbhum Craton: implications for origin, age of BIF-hosted high-grade iron ores and stratigraphy of the Iron Ore Group. Journal of the Geological Society of India, v. 70, pp. 34.

Mukhopadhyay, J., Crowley, Q.G., Ghosh, S., Ghosh, G., Chakrabarti, K., Misra, B., Heron, K., and Bose, S., 2014, Oxygenation of the Archean atmosphere: New paleosol constraints from eastern India. Geology, v. 42, pp. 923-926.

Mukhopadhyay, J., Crowley, Ghosh, G., Ghosh, S., Chakrabarti, K., Misra B. and Bose, S., 2013, A Mesoarchean Paleosol from eastern India - the second oldest paleosol on earth. Mineralogical Magazine, v. 77, pp. 1802.

Mukhopadhyay, J., Ghosh, G., Nandi, A.K., and Chaudhuri, A.K., 2006, Depositional setting of the Kolhan Group: its implications for the development of a Meso to Neoproterozoic deep-water basin on the South Indian craton. South African Journal of Geology, v. 109, pp. 183-192.

Mukhopadhyay, J., Ghosh, G., Zimmermann, U., Guha, S., and Mukherjee, T., 2012, A 3.51 Ga bimodal volcanics-BIF-ultramafic succession from Singhbhum Craton: implications for Palaeoarchaean geodynamic processes from the oldest greenstone succession of the Indian subcontinent. Geological Journal, v. 47, pp. 284-311.

Mukhopadhyay, J., Gutzmer, J., Beukes, N.J. and Bhattacharya, H.N., 2008a, Geology and genesis of banded iron formation-hosted high-grade iron ore deposits of India. Society of Economic Geologists Reviews, v. 15, pp. 291-316.

Mukhopadhyay, J., Gutzmer, J., Beukes N. J. and Hayashi, K..I., 2008b, Stratabound magnetite deposits from the eastern outcrop belt of the Archean Iron Ore Group, Singhbhum craton, India. Applied Earth Science (Trans. Inst. Min. Metall. B), v. 117, pp. 175-186. DOI 10.1179/174327508X387492.

Mukhopadhyay, J., Mishra, B., Chakrabarti, K., De, S., and Ghosh, G., 2016, Uraniferous paleoplacers of the Mesoarchean Mahagiri Quartzite, Singhbhum craton, India: Depositional controls, nature and source of $>3.0 \mathrm{Ga}$ detrital uraninites. Ore Geology Reviews, v. 72 , pp. $1290-1306$.

Murthy, V.N., and Acharya, S., 1975, Lithostratigraphy of the Precambrian rocks around Koira, Sundergarh district, Orissa. Journal of the Geological Society of India, v. 16, pp. 55-68.

Myers, J.S., 1995, The generation and assembly of an Archean supercontinent: evidence from the Yilgarn Craton, Western Australia. In: Coward M.P., and Ries, A.C. (Eds.), Early Precambrian Processes. Geological Society of London, Special Publication, 95, pp. 143-154.

Nadeau, S., Chen, W., Reece, J., Lachhman, D., Ault, R., Faraco, M. T. L., Fraga, L. M., Reis, N. J., and Betiollo, L. M., 2013, Guyana: the Lost Hadean crust of South America? Brazil Journal of Geology, v. 43, pp. 601-606.

Nadoll, P., Angerer, T., Mauk, J.L., French, D., and Walshe, J., 2014, The chemistry of hydrothermal magnetite: a review. Ore geology reviews, v. 61, pp. 1-32.

Nägler, T.F., Kramers, J.D.,Kamber, B.S., Frei, R., and Prendergast, M.D.A., 1997, Growth of subcontinental lithospheric mantle beneath Zimbabwe started at or before 3.8 Ga: Re-Os study on chromites. Geology, v. 25, pp. 983-986.

Naha, K., 1954, A note on the continuation of the Singhbhum shear belt in eastern Mayurbhanj. Science \& Culture, v. 20, pp. 295297.

Naha, K., 1960, Granitic emplacement in relation to thrusting in south Dhalbhum and northeastern Mayurbhanj. Quarterly Journal of
Geological Mining and Metallurgical Society of India, v. 32, pp. 115-122.

Naik, A., 2001, A revision of the stratigraphy of Chandiposh area in eastern part of Sundargarh District, Orissa. Indian Journal of Geology, v. 73, pp. 119-137.

Naqvi, S. M., and Rodgers, J. J. W., 1987, Precambrian Geology of India. Oxford University Press, 223p.

Nelson, D. R., Bhattacharya, H., Thern, E. R., and Altermann, W., 2014, Geochemical and ion-microprobe U-Pb zircon constraints on the Archaean evolution of Singhbhum Craton, eastern India. Precambrian Research, v. 255, pp. 412-432.

Nelson, D.R., Robinson, B.W., and Myers, J.S., 2000, Complex geological histories extending for e"4.0 Ga deciphered from xenocryst zircon microstructures. Earth and Planetary Science Letters, v. 181, pp. 89-102.

Nisbet, E.G., 1987, The Young Earth. Allen and Unwin, Boston, 402 p.

Nutman, A.P., Bennett, V.C., Friend, C.R., and Rosing, M.T., 1997, $\sim 3710$ and $~ 3790$ Ma volcanic sequences in the Isua (Greenland) supracrustal belt; structural and Nd isotope implications. Chemical Geology, v. 141, pp. 271-287.

Nutman, A.P., Friend, C.R., Baadsgaard, H., and McGregor, V.R., 1989, Evolution and assembly of Archean gneiss terranes in the Godthåbsfjord region, southern West Greenland: structural, metamorphic, and isotopic evidence. Tectonics, v. 8, pp. 573589.

Nutman, A.P., Friend, C.R., Horie, K., and Hidaka, H., 2007, The Itsaq Gneiss Complex of Southern West Greenland and the Construction of Eoarchaean Crust at Convergent Plate Boundaries. In: Van Kranendonk, M. J., Smithies, R. H., and Bennett, V. (Eds.), Earth's Oldest Rocks. Developments in Precambrian Geology, v. 15, p. 187-218.

Olierook, H. K. H., Clark, C., Reddy, S. M., Mazumder, R., Jourdan, F., and Evans, N. J., 2019, Evolution of the Singhbhum Craton and supracrustal provinces from age, isotopic and chemical constraints. Earth-Science Reviews, In press, https://doi.org/ 10.1016/j.earscirev.2019.04.020.

O’neil, J., Carlson, R.W., Francis, D., and Stevenson, R.K., 2008, Neodymium-142 evidence for Hadean mafic crust. Science, v. 321, pp. 1828-1831.

O’Neil, J., Carlson, R.W., Paquette, J.L., and Francis, D., 2012, Formation age and metamorphic history of the Nuvvuagittuq Greenstone Belt. Precambrian Research, v. 220, pp. 23-44.

Pandey, O.P., Mezger, K., Ranjan, S., Upadhyay, D., Villa, I.M., Nägler, T.F., and Vollstaedt, H., 2019, Genesis of the Singhbhum Craton, eastern India; implications for Archean crust-mantle evolution of the Earth. Chemical Geology, v. 512, pp. 85-106.

Paul, D. K., Mukhopadhayay, D., Pyne, T., and Bishui, P., 1991, RbSr age of granitoid in the Deo River section, Singhbhum and its relevance to the age of iron formation. Indian Minerals, v. 45, pp. 51-56.

Polat, A., Appel, P.W., and Fryer, B.J., 2011, An overview of the geochemistry of Eoarchean to Mesoarchean ultramafic to mafic volcanic rocks, SW Greenland: implications for mantle depletion and petrogenetic processes at subduction zones in the early Earth. Gondwana Research, v. 20, pp. 255-283.

Polat, A. and Frei, R, 2005, The origin of early Archean banded iron formations and of continental crust, Isua, southern West Greenland. Precambrian Research, 138, 151-175..

Polat, A., Hofmann, A., and Rosing, M.T., 2002, Boninite-like volcanic rocks in the 3.7-3.8 Ga Isua greenstone belt, West Greenland: geochemical evidence for intra-oceanic subduction zone processes in the early Earth. Chemical geology, v. 184, pp. 231-254. 
Polat, A., Kerrich, R., and Wyman, D., 1998, The late Archean Schreiber-Hemlo and White River-Dayohessarah greenstone belts, Superior Province: collages of oceanic plateaus, oceanic arcs, and subduction-accretion complexes. Tectonophysics, v. 289, pp. 295-326.

Polat, A., Kokfelt, T., Burke, K.C., Kusky, T.M., Bradley, D.C., Dziggel, A., and Kolb, J., 2016., Lithological, structural, and geochemical characteristics of the Mesoarchean Târtoq greenstone belt, southern West Greenland, and the Chugach-Prince William accretionary complex, southern Alaska: evidence for uniformitarian plate-tectonic processes. Canadian Journal of Earth Sciences, v. 53, pp. 1336-1371.

Polat, A., Li, J., Fryer, B., Kusky, T., Gagnon, J., and Zhang, S., 2006, Geochemical characteristics of the Neoarchean (2800-2700 $\mathrm{Ma})$ Taishan greenstone belt, North China Craton: evidence for plume-craton interaction. Chemical Geology, v. 230, pp. 60-87.

Prabhakar, N., and Bhattacharya, A., 2013, Paleoarchean partial convective overturn in the Singhbhum Craton, Eastern India. Precambrian Research, v. 231, pp. 106-121.

Prasada Rao, G., Murty, Y., and Deekshitulu, M., 1964, Stratigraphic relations of Precambrian iron formations and associated sedimentary sequences in parts of Keonjhar, Cuttack, Dhenkanal and Sundergarh districts of Orissa, India. Proceedings 22nd Internationa Geological Congress, India, Sec. X, pp. 72-87.

Puchtel, I., Hofmann, A., Mezger, K., Jochum, K., Shchipansky, A., and Samsonov, A., 1998, Oceanic plateau model for continental crustal growth in the Archaean: a case study from the Kostomuksha greenstone belt, NW Baltic Shield. Earth and Planetary Science Letters, v. 155, pp. 57-74.

Rai, K. L., Sarkar, S. N., and Paul, P. R., 1980, Primary depositional and diagenetic features in the banded iron formation and associated iron-ore deposits of Noamundi, Singhbhum district, Bihar, India. Mineralium Deposita, v. 15, pp. 189-200.

Ray, S.L, Saha, A., and Ghosh, S., 1987, Nature of the oldest known metasediments from eastern India. Indian Minerals, v. 41, pp. 52-60.

Ray, S. L., Sarkar, S. S., Saha, A. K., and Sarkar, S. N., 1991, REE distribution in the early Archaean amphibolites of the SinghbhumOrissa iron ore craton, eastern India. Indian Minerals, v. 45, pp. 19-32.

Raza, M., Alvi, S.H., and Abu-Hamatter, Z.S.H., 1995, Geochemistry and tectonic significance of Ongarbira volcanics, Singhbhum craton, eastern India. Journal Geological Society of India, v. 45, pp. 643-652.

Reimink, J. R., Chacko, T., Stern, R. A., and Heaman, L. M., 2014, Earth's earliest evolved crust generated in Iceland-like setting. Nature Geoscience, v. 7, pp. 529-533.

Reimink, J.R., Davies, J.H.F.L., Chacko, T., Stern, R.A., Heaman, L.M., Sarkar, C., Schaltegger, U., Creaser, R.A., and Pearson, D.G., 2016, No evidence for Hadean continental crust within Earth’s oldest evolved rock unit. Natural Geoscience, v. 9, pp. 777-780.

Roy, A., and Sarkar, A., 2006, Geochronological constraints on evolution of Singhbhum mobile belt and associated basic volcanics of Eastern Indian shield-comment. Gondwana Research, v. 9, pp. 541-542.

Roy, A., Sarkar, A., Jayakumar, S., Aggarwal, S. K., Ebihara, M. and Satoh, H., 2004, Late Archaean mantle metasomatism below eastern Indian craton: Evidence from trace elements, REE geochemistry and Sr-Nd-O isotope systematics of ultramafic dykes. Proceedings of the Indian Academy of Sciences-Earth and Planetary Science, v. 113, pp. 649-665.

Roy, A., Sarkar, A., Jeyakumar, S., and Ebihara, M., 2002, Sm-Nd age and mantle source characteristics of the Dhanjori volcanic rocks, eastern India. Geochemical Journal, v. 36, pp. 503-518.

Roy, A.B., and Bhattacharya, H.N., 2012, Tectonostratigraphic and geochronologic reappraisal constraining the growth and evolution of Singhbhum Archaean craton, eastern India. Journal Geological Society of India, v. 80, pp. 455-469.

Saha, A., Basu, A.R., Garzione, C.N., Bandyopadhyay, P.K., and Chakrabarti, A., 2004, Geochemical and petrological evidence for subduction-accretion processes in the Archean Eastern Indian Craton. Earth and Planetary Science Letters, v. 220, pp. 91-106.

Saha, A. K., 1972, Petrogenetic and structural evolution of the Singhbhum granite complex, eastern India. Proceedings of the 24th International Geological Congress, pp. 147-155.

Saha, A.K., 1994, Crustal evolution of Singhbhum-North Orissa, eastern India. Journal of the Geological Society of India, Memoir, v. 27, pp. 341.

Saha, A. K., Bose, R., Ghosh, S. N. and Roy, A., 1977, Petrology and emplacement of Mayurbhanj Granite batholith, eastern India. Evolution of Orogenic Belts of India (Part 2), Bulletin of the Geological Mining and Metallurgical Society of India, v. 49, pp. 1-34.

Saha, A. K., Ghosh, S. N., Dasgupta, D., Mukhopadhyay, K., and Ray, S. L., 1984, Studies on crustal evolution of the SinghbhumOrissa Iron-Ore craton. Crustal Evolution and Metallogenesis in Selected Areas of the Indian Shield. Indian Society of Earth Science, Monograph Volume, Calcutta, v. pp. 1-74.

Saha, A. K., and Ray, S. L., 1984, The structural and geochemical evolution of the Singhbhum granite batholithic complex, India. Tectonophysics, v. 105, pp. 163-176.

Saha, A. K., Ray, S.L., and Sarkar, S.N., 1988. Early history of the earth: Evidence from the eastern India shield. Memoir, Geological Society of India, v. 8, pp. 13-38.

Saha, A. K., Sankaran, A.V., and Bhattacharyya, T.K., 1973, Geochemistry of Newer Dolerite suite of intrusions within the Singhbhum Granite. Journal of the Geological Society of India, v. 14, pp. 113-121.

Saha, L., Hofmann, A., and Xie, H., 2012a, Style of Palaeoarchaean tectonics from the SE Kaapvaal and Singhbhum Cratons: Constraints from metamorphic studies and zircon geochronology. EGU General Assembly Conference Abstracts, Geophysical Research Abstracts, v. 14, pp. 3549.

Saha, L., Hofmann, A., and Xie, H., 2012b, Archaean evolution of the Singhbhum Craton: constraints from new metamorphicgeochemical data and SHRIMP zircon ages. In: Abstract Volume, Conference on Craton Formation and Destruction, University of Johannesburg, 21-22 July, pp. 7-9.

Sahu, N.K., Mukherjee, M.M., 2001, Spinifex textured komatiite from Badampahar-Gorumahisani schist belt, Mayurbhanj District, Orissa. Journal of Geological Society of India, v. 57, pp. 529534.

Santosh, M., Arai, T. and Maruyama, S., 2017, Hadean Earth and primordial continents: The cradle of prebiotic life. Geoscience Frontiers, v. 8, pp. 309-327.

Sarkar, B., 1984, Microfossils in the banded iron formation from the Noamundi basin, eastern India. Quarternary Journal of Geological Mining and Metallurgica Society of India, v. 56, pp. 41-46.

Sarkar, B., 1989, Algal stromatolites and associated microbiota of the Precambrian banded iron formation in Noamundi Basin, eastern India. Himalayan Geology, v. 13, pp. 29-37.

Sarkar, S.C. and Gupta, A., 2012, Crustal evolution and metallogeny in India. Cambridge University Press. pp. 840.

.Sarkar, S.N. and Saha, A.K., 1962, A revision of the Precambrian stratigraphy and tectonics of Singhbhum and adjacent regions, Quarternary Journal of Geological Mining and Metallurgica Society of India, v. 34, pp. 97-136. 
Sarkar, S.N. and Saha, A.K., 1977, The present status of the Precambrian stratigraphy, tectonics and geochronology of Singhbhum-Keonjhar-Mayurbhanj region, Eastern India. Indian Journal of Earth Sciences, Prof. S. Ray Volume, pp. 37-65.

Sarkar, S. N., and Saha, A. K., 1983, Structure and tectonics of the Singhbhum-Orissa Iron Ore Craton, eastern India, In: Recent Researches in Geology, v. 10, pp. 1-25. Hindustan Publishing corporaion, New Delhi.

Sarkar, S. N., Saha, A. K., Boelrijk, N. A. I. M. and Hebeda, E. H., 1979, New data on the geochronology of the Older Metamorphic Group and the Singhbhum Granite of Singhbhum-Keonjhar Mayurbhanj region, eastern India. Indian Journal of Earth Science, v. 6, pp. 32-51.

Sarkar, S. N., Saha, A. K., and Sen, S., 1990, Structural pattern of Pala Lahara area, Dhenkanal district, based on ground data, Indian Journal of Earth Science, v. 17, pp. 128-137.

Sen, T., 2001, Stratigraphy and structure of the metamorphic belt at the nothern fringe of Bonai granitic complex in the southeastern part of Sundargarh district, Orissa. Geological Survery of India, Splecial Publication v. 55, pp. 113-128.

Sengupta, S., Acharyya, S., and DeSmeth, J. B., 1997, Geochemistry of Archaean volcanic rocks from Iron Ore supergroup, Singhbhum, eastern India. Proceedings of the Indian Academy of Sciences-Earth and Planetary Sciences, v. 106, pp. 327.

Sengupta, S., Bandopadhyay, P., De Smeth, J. B., and Maitra, M., 1993, Petrogenesis of granitoid components from Bonai pluton and its implication on the formation of the eastern Indian Archaean sialic crust. Proceedings of the Indian Academy of Sciences India section A, v. 63, pp. 189-189.

Sengupta, S., Corfu, F., McNutt, R., and Paul, D. K., 1996, Mesoarchaean crustal history of the eastern Indian craton: Sm$\mathrm{Nd}$ and U-Pb isotopic evidence. Precambrian Research, v. 77, pp. 17-22.

Sengupta, S., Paul, D. K., De Laeter, J., McNaughton, N., Bandopadhyay, P., and De Smeth, J., 1991, Mid-Archaean evolution of the eastern Indian craton: geochemical and isotopic evidence from the Bonai pluton. Precambrian Research, v. 49, pp. 23-37.

Shankar, R., Vijayagopal, B., and Kumar, A., 2014, Precise Pb-Pb baddeleyite ages of 1765 Ma for a Singhbhum 'Newer Dolerite' dyke swarm. Current Science, v. 106, pp. 1306-1310.

Sharma, M., Basu, A.R., and Ray, S.L., 1994, Sm-Nd isotopic and geochemical study of the Archean tonalite-amphibolite association from the eastern Indian Craton. Contributions to Mineralogy and Petrology, v. 117, pp. 45-55.

Singh, M.R., Manikyamba, C., Ganguly, S., Ray, J., Santosh, M., Singh, T.D., and Kumar, B.C., 2017, Paleoproterozoic arc basaltboninite-high magnesian andesite-Nb enriched basalt association from the Malangtoli volcanic suite, Singhbhum Craton, eastern India: geochemical record for subduction initiation to arc maturation continuum. Journal of Asian Earth Sciences, v. 134, pp. 191-206.

Singh, M.R., Manikyamba, C., Ray, J., Ganguly, S., Santosh, M., Saha, A., Rambabu, S., and Sawant, S., 2016, Major, trace and platinum group element (PGE) geochemistry of Archean Iron Ore Group and Proterozoic Malangtoli metavolcanic rocks of Singhbhum Craton, Eastern India: Inferences on mantle melting and sulphur saturation history. Ore Geology Reviews, v. 72, pp. 1263-1289.

Sreenivas, B., Dey, S., Rao, Y.B., Kumar, T.V., Babu, E., and Williams, I.S., 2019, A new cache of Eoarchaean detrital zircons from the Singhbhum craton, eastern India and constraints on early Earth geodynamics. Geoscience Frontiers, (In Press), https://doi.org/ 10.1016/j.gsf.2019.02.001.
Srivastava, R.K., Söderlund, U., Ernst, R.E., Mondal, S.K., and Samal, A.K., 2016, Neoarchaean-Palaeoproterozoic Mafic Dyke Swarms from the Singhbhum Granite Complex, Singhbhum Craton, Eastern India: implications for identification of Large Igneous Provinces and their possible continuation on other formerly adjacent crustal blocks. Acta Geologica Sinica (English Edition), v. 90, pp. 17-18.

Srivastava, R.K., Söderlund, U., Ernst, R.E., Mondal, S. K. and Samal, A.K., 2019, Precambrian mafic dyke swarms in the Singhbhum craton (eastern India) and their links with dyke swarms of the eastern Dharwar craton (southern India). PrecambriannResearch, In press. https://doi.org/10.1016/j.precamres.2018.08.001.

Stern, R. J., 2018, The evolution of plate tectonics. Philosophical Transaction Royal Society. A 376, 20170406. http://dx.doi.org/ 10.1098/rsta.2017.0406.

Sunilkumar, T., Parthasarathy, R., Palrecha, M., Shah, V., Sinha, K., and Krishna Rao, N., 1996, Chemical age of detrital zircons from the basal quartz-pebble conglomerate of Dhanjori Group, Singbhum craton, Eastern India. Current Science, v. 71, pp. 482486.

Tait, J., Zimmermann, U., Miyazaki, T., Presnyakov, S., Chang, Q., Mukhopadhyay, J., and Sergeev, S., 2011, Possible juvenile Palaeoarchaean TTG magmatism in eastern India and its constraints for the evolution of the Singhbhum craton. Geological Magazine, v. 148, pp. 340-347.

Topno, A., Dey, S., Liu, Y., and Zong, K., 2018, Early Neoarchaean A-type granitic magmatism by crustal reworking in Singhbhum craton: Evidence from Pala Lahara area, Orissa. Journal of Earth System Science, v. 127, pp 43 /1-22.

Upadhyay, D., Chattopadhyay, S., Kooijman, E., Mezger, K., and Berndt, J., 2014, Magmatic and metamorphic history of Paleoarchean tonalite-trondhjemite-granodiorite (TTG) suite from the Singhbhum craton, eastern India. Precambrian research, v. 252, pp. 180-190.

Van Kranendonk, M.J., 2010, Two types of Archean continental crust: Plume and plate tectonics on early Earth. American Journal of Science, v. 310, pp. 1187-1209.

Van Kranendonk, M.J., Collins, W., Hickman, A., and Pawley, M.J., 2004, Critical tests of vertical vs. horizontal tectonic models for the Archaean East Pilbara granite-greenstone terrane, Pilbara craton, western Australia. Precambrian Research, v. 131, pp. 173211.

Van Kranendonk, M.J., Smithies, R.H., Griffin, W.L., Huston, D.L., Hickman, A.H., Champion, D.C., Anhaeusser, C.R., and Pirajno, F., 2015, Making it thick: a volcanic plateau origin of Palaeoarchean continental lithosphere of the Pilbara and Kaapvaal cratons. Geological Society of London, Special Publication, 389, pp. 83-111.

Verma, R.K., and Prasad, S.N., 1974, Paleomagnetic study and chemistry of Newer Dolerite from Singhbhum, Bihar, India. Canadian Journal of Earth Science, v. 11, pp. 1043-1054.

Vohra, C. P., Dasgupta, S., Paul, D. K., Bishui, P., Gupta, S., and Guha, S., 1991, Rb-Sr chronology and petrochemistry of granitoids from the south-eastern part of the Singhbhum craton, Orissa. Journal of the Geological Society of India, v. 38, pp. 522.

Wan, Y. S., Liu, D. Y., Dong, C. Y., Xie, H. Q., Kröner, A., Ma, M. Z., Liu, S. J., Xie, S. W. and Ren, P., 2015, Formation and evolution of Archean continental crust of the North China Craton, Precambrian geology of China. Springer-Verlag, Berlin, pp. 59136.

Wilde, S.A., Valley, J.W., Peck, W.H., and Graham, C.M., 2001, Evidence from detrital zircons for the existence of continental crust and oceans on the Earth 4.4 Gyr ago. Nature, v.409, pp.175. 
Winter, J.D., 2010, Principles of igneous and metamorphic petrology. Pearson education. $737 \mathrm{p}$.

Wyche, S., Nelson, D. and Riganti, A., 2004, 4350-3130 Ma detrital zircons in the Southern Cross Granite-Greenstone Terrane, Western Australia: implications for the early evolution of the Yilgarn Craton. Australian journal of Earth sciences, v. 51, pp. 31-45.

Zeh, A., Gerdes, A., and Barton Jr, J.M., 2009, Archean accretion and crustal evolution of the Kalahari Craton-the zircon age and $\mathrm{Hf}$ isotope record of granitic rocks from Barberton/Swaziland to the Francistown Arc. Journal of Petrology, v. 50, pp. 933-966.

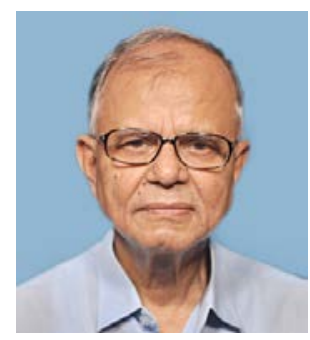

Professor D. Mukhopadhyay has taught at the Presidency College, Kolkata, Indian School of Mines Dhanbad and University of Calcutta. His specialization is on Structural Geology and Precambrian Geology. He has worked on the Precambrians of Karnataka, Singhbhum, Rajasthan and Central India. His researches also include topics of mechanics of folding, geometry of superposed folding, strain analysis in deformed rocks and neotectonics and active faulting. He is a Fellow of the Indian National Science Academy, Indian Academy of Sciences and National Academy of Sciences India.
Zeh, A., Gerdes, A., Klemd, R., and Barton Jr, J., 2008, U-Pb and $\mathrm{Lu}-\mathrm{Hf}$ isotope record of detrital zircon grains from the Limpopo Belt-evidence for crustal recycling at the Hadean to earlyArchean transition. Geochimica Cosmochimica Acta, v. 72, pp. 5304-5329.

Zeh, A., Gerdes, A., and Millonig, L., 2011, Hafnium isotope record of the Ancient Gneiss Complex, Swaziland, southern Africa: evidence for Archaean crust-mantle formation and crust reworking between 3.66 and $2.73 \mathrm{Ga}$. Journal of the Geological Society fo London, v. 168, pp. 953-964.

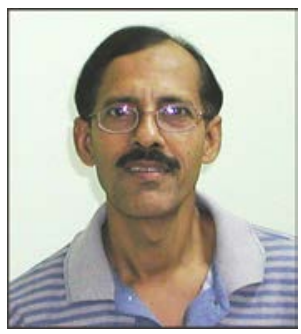

Abdul Matin is retired Professor of Geology at the University of Calcutta, India. $\mathrm{He}$ received his doctorate degree from the Indian School of Mines, Dhanbad, India. Besides his 35 years of teaching experience he was involved in research in the field of structural geology, tectonics and sedimentology. His interests are in Precambrian geology, Proterozoic basins, Himalayan geology and in shear zones. 